UNIVERSIDADE DE SÃO PAULO

INSTITUTO DE QUÍMICA DE SÃO CARLOS

Daniele Marcondes Ferreira

ABORDAGEM INVESTIGATIVA NO ENSINO PÚBLICO NOTURNO:

CONTRIBUIÇÕES PARA A FORMAÇÃO DO ESPÍRITO CIENTÍFICO E PARA A PESQUISA-AÇÃO

São Carlos

2020 
DANIELE MARCONDES FERREIRA

\section{ABORDAGEM INVESTIGATIVA NO ENSINO PÚBLICO NOTURNO: CONTRIBUIÇÕES PARA A FORMAÇÃO DO ESPÍRITO CIENTÍFICO E PARA A PESQUISA-AÇÃO}

Tese apresentada ao Instituto de Química de São Carlos da Universidade de São Paulo para a obtenção do título de Doutora em Ciências.

Área de Concentração: QUÍMICA ANALÍTICA E INORGÂNICA.

Orientadora: Profa. Dra. Ana Cláudia Kasseboehmer.

São Carlos 
Autorizo a reprodução e divulgação total ou parcial deste trabalho, por qualquer meio convencional ou eletrônico para fins de estudo e pesquisa, desde que citada a fonte.

\section{Assinatura:}

Data:

Ficha Catalográfica elaborada pela Seção de Referência e Atendimento ao Usuário do SBI/IQSC

Ferreira, Daniele Marcondes

Abordagem investigativa no ensino público noturno: contribuições para a formação do espírito científico e para a pesquisa-ação. / Daniele Marcondes Ferreira. - São Carlos, 2020.

$130 \mathrm{f}$.

Tese (Doutorado em Química Analítica e Inorgânica) — Instituto de Química de São Carlos / Universidade de São Paulo, 2020.

Orientadora: Profa. Dra. Ana Cláudia Kasseboehmer

1. Ensino. 2. Ensino público. I. Título.

Sonia Alves - CRB: 4280/8 


\section{Agradecimentos}

$\checkmark$ Inicialmente, gostaria de agradecer a Deus pelo dom da vida e pela minha família, meus pais e minhas irmãs que sempre se fizeram presentes e me apoiaram desde o início desta jornada.

$\checkmark$ Gostaria de agradecer à professora Ana Cláudia pelas orientações, discussões e paciência durante esses quatro anos que, com muito carinho e esmero, se preocupou com todo o andamento do projeto, além de estabelecer parceria com a escola que atualmente leciono. Grata por tudo!

$\checkmark$ Agradeço também aos colegas do laboratório LINECIN, em especial Ana Carolina, Daniel e Kenia, pelas discussões científicas, seja durante os estudos ou durante o cafezinho, nas poucas tardes em que passei no laboratório.

$\checkmark$ Aos alunos que participaram tanto do estudo piloto quanto da coleta de dados, pela prontidão e empenho para a realização das atividades.

$\checkmark$ Aos professores Luiz e Nelma pelas contribuições durante o exame de qualificação.

$\checkmark$ Agradeço à direção da Escola José Ferreira da Silva, a qual leciono há oito anos e que prontamente abriu as portas, abraçou este projeto, culminando na reativação do laboratório didático.

$\checkmark$ E um agradecimento especial para meu namorido Rafael, que sempre acreditou no meu potencial, mesmo trabalhando em três escolas, fazendo um doutorado e namorando a distância, não desistiu de nós. Obrigada por todo apoio e suporte que você sempre me deu! Te amo! 


\section{RESUMO}

O presente trabalho tem como objetivo geral avaliar a contribuição do uso da abordagem investigativa para a formação do espírito científico dos estudantes e para a pesquisa-ação da professora. Para tanto, foram aplicadas atividades investigativas em níveis de 1 a 5 de abertura durante as aulas de Química no Ensino Médio público noturno na cidade de Descalvado. Para a aplicação das atividades, foi realizada uma adaptação curricular a fim de que o conteúdo pudesse ser desenvolvido em paralelo com a aplicação das atividades investigativas. A abordagem investigativa foi escolhida devido ao fato de promover uma participação efetiva do aluno. Por meio desta estratégia é possível para o aluno elaborar hipóteses, propor um procedimento experimental, coletar dados, analisar os resultados e elaborar uma conclusão. A pesquisa realizada foi do tipo qualitativa, com participação de alunos de primeiro e segundo anos do Ensino Médio. O desenvolvimento da pesquisa foi realizado pela professora da turma na forma de pesquisa-ação. Os instrumentos utilizados para análise foram: aplicação de questionários, observação descrita no diário de bordo e entrevistas. A análise foi realizada com base na teoria da formação do espírito científico de Gaston Bachelard. A partir dos dados coletados foi possível concluir que é factível a aplicação de atividades investigativas de nível 1 a 4 em sala de aula. O nível 5 só é possível ser aplicado quando há uma consolidação do nível 4, visto que este nível exige maturidade e autonomia do aluno. A contar da aplicação das atividades investigativas, foi possível promover um processo de perturbação em suas crenças, conhecimentos prévios, além de tornarem os alunos mais curiosos para aprender química. Os dados obtidos durante a pesquisa ainda são muito sutis para afirmar a formação do espírito científico nos alunos que participaram do estudo, o que demandaria um estudo por maior tempo. Apesar dos dados referentes ao nível 5 não terem sido o esperado, o estudo mostra caminhos que podem ser trilhados pelos professores que desejam fazer uso de estratégias investigativas em aulas de Química.

Palavras-chave: química; pesquisa-ação; atividades investigativas; espírito científico; Gaston Bachelard. 


\begin{abstract}
The present work has as general aim to evaluate the contribution of the use of the inquiry approach for the formation of the scientific spirit of the students and the action research of the teacher. For that, inquiry activities of levels 1 to 5 were applied during the high school Chemistry classes at night period in the city of Descalvado. To apply the activities, a curricular adaptation was carried out so the content could be developed in parallel with the application of inquiry activities. The inquiry approach was chosen because it promotes effective student participation. Through this strategy it is possible for the student to elaborate hypothesis, develop an experimental procedure, collect data, analyze the results and draw a conclusion. We performed the qualitative type of research with the participation of high school students from first and second year. The research was developed by the teacher from the class in the format of action research. The instruments used for the analysis were application of questionnaires, observation described in the logbook and interviews. The analysis was based on the theory of the formation of the scientific spirit of Gaston Bachelard. From the data collected it was possible to conclude that it is possible to apply inquiry activities from level 1 to 4 . Level 5 is only possible when there is a consolidation of level 4, since this level requires maturity and autonomy of the student. From the application of investigative activities, it was possible to promote a process of disturbance in their beliefs, previous knowledge, in addition to making students more curious to learn Chemistry. The data obtained during the research are still very subtle to affirm the formation of the scientific spirit in the students who were under the study, which would require a study for a longer time. Although the data referring to level 5 were not as expected, the study shows paths that can be taken by teachers who wish to make use of inquiry strategies in Chemistry classes.
\end{abstract}

Keywords: Chemistry; action research; inquiry activities; scientific spirit; Gaston Bachelard. 


\section{LISTA DE FIGURAS}

Figura 1 - Níveis de representação do conhecimento químico

Figura 2 - Primeira atividade experimental dos alunos realizada em sala de aula 50

Figura 3 - Grupo 1: Apresentação do quarto experimento (nível 5) no início (a esquerda) e no final da aula (a direita) 87

Figura 4 - Grupo 2: Teste de condutividade do limão (nível 5) 92

Figura 5 - Resultado do teste de condutividade com o acendimento do LED (nível 5) 93

Figura 6 - Grupo 4: Teste de dissolução do isopor em acetona (nível 5) 97 


\section{LISTA DE QUADROS}

Quadro1 - Níveis de abertura do experimento. P - professor; E - estudante 26

Quadro 2 - Cronograma de atividades aplicadas durante o primeiro semestre de 2018 40

Quadro 3 - Cronograma de atividades aplicadas durante o segundo semestre de 2018

Quadro 4 - Sequência de respostas de um aluno que participou de todas as atividades investigativas

Quadro 5 - Sequência de respostas da Aluna 13 que participou de todas as atividades investigativas

Quadro 6 - Resumo das respostas apresentadas pelo grupo 1 durante as atividades experimentais investigativas de nível 5

Quadro 7 - Resumo das respostas apresentadas pelo grupo 2 durante as atividades experimentais investigativas de nível 5

Quadro 8 - Resumo das respostas apresentadas pelo grupo 4 durante as atividades experimentais investigativas de nível 5 


\section{LISTA DE TABELAS}

Tabela 1 - Frequência das respostas dos alunos referentes às transformações físicas e químicas

Tabela 2 - Comparação de respostas dos alunos referentes à Reação entre $\mathrm{HCl}$ e Zn metálico utilizando sistema aberto e fechado

Tabela 3 - Reação de magnésio metálico com $\mathrm{O}_{2}$ - comparações entre sistema aberto e fechado

Tabela 4 - Reação de sulfato de cobre II e hidróxido de sódio realizada no sistema aberto e fechado

Tabela 5 - Reação entre ácido clorídrico e hidróxido de sódio em sistema aberto e fechado

Tabela 6 - Reação entre Hidróxido de sódio com fenolftaleína (Evidência da transformação)

Tabela 7 - Dados obtidos após atividade partícula na caixa no $1^{\circ}$ ano do Ensino Médio

Tabela 8 - Dados obtidos após atividade partícula na caixa no $2^{\circ}$ ano do Ensino Médio 63

Tabela 9 - Frequência das conclusões apresentadas pelos alunos em relação ao experimento sobre densidade

Tabela 10 - Classificação e frequência das respostas em relação à elaboração da hipótese inicial pelos alunos sobre chuva ácida

Tabela 11 - Análise da capacidade de elaboração de roteiro experimental utilizando o método investigativo

Tabela 12 - Análise dos resultados obtidos por meio da metodologia proposta pelos alunos

Tabela 13 - Análise da (capacidade) elaboração de hipótese utilizando o método investigativo 
Tabela 14 - Análise da capacidade de elaboração de procedimento experimental utilizando o método investigativo 75

Tabela 15 - Análise da capacidade de elaborar a conclusão do experimento 76 
SUMÁRIO

CAPÍTULO 1 13

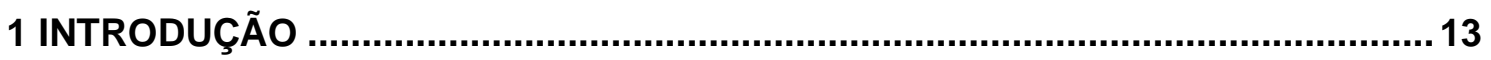

1.2 A problemática do Ensino Médio no período noturno........................ 16

1.3 Referencial teórico: Gaston Bachelard .............................................. 18

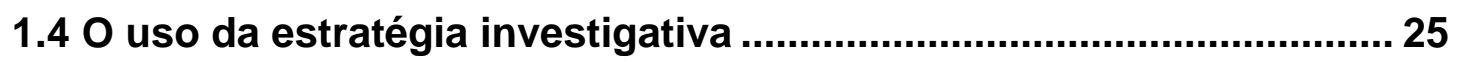

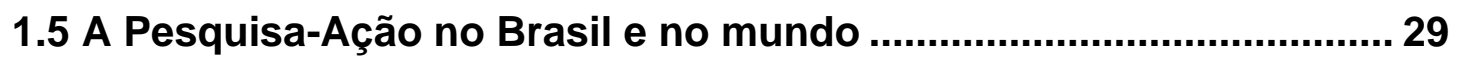

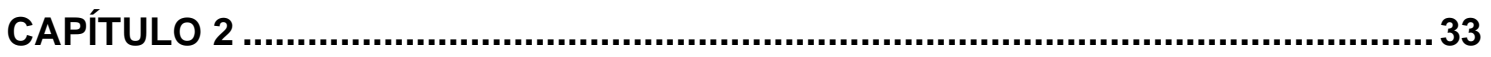

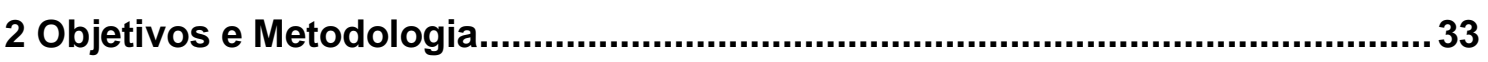

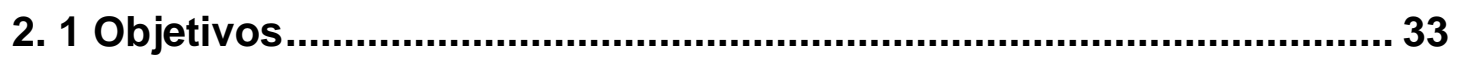

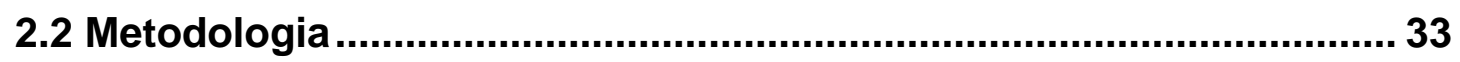

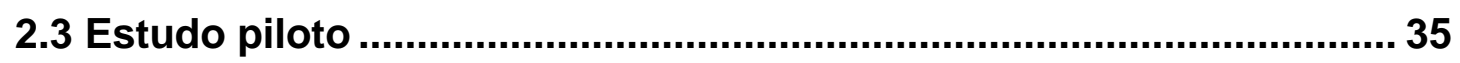

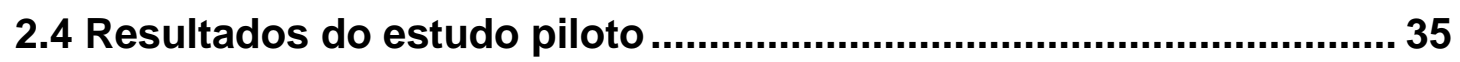

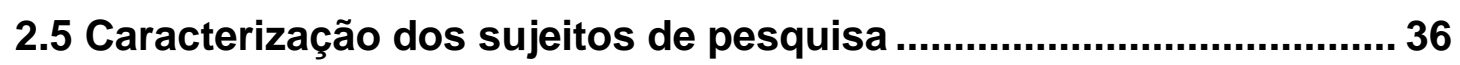

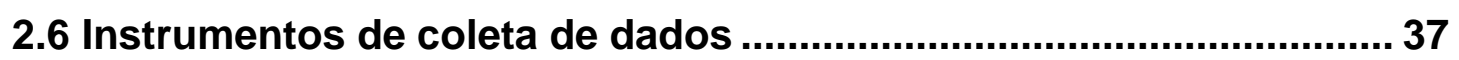

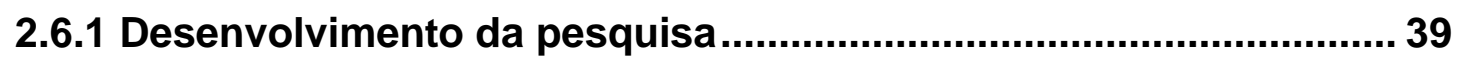

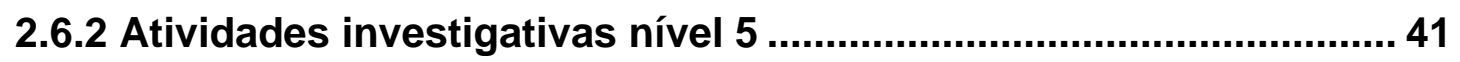

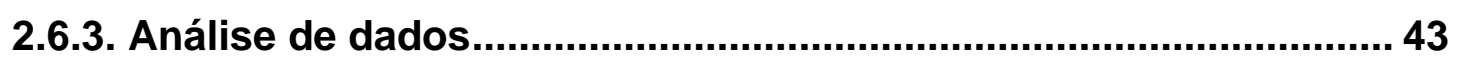

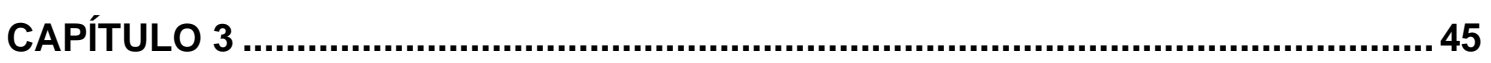

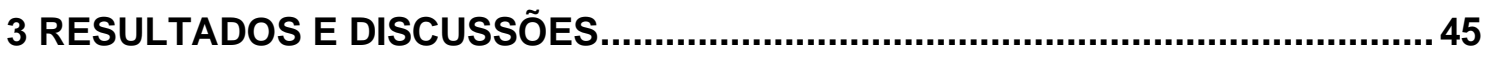

3.1 Atividade 1: Evidência das reações químicas .................................... 45

3.2 Atividade nível 1: identificação das evidências de reação................ 49

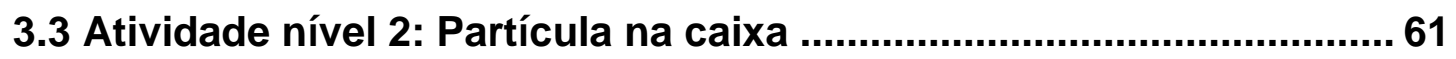

3.4 Atividade nível 2: densidade de um sólido não poroso .................... 64

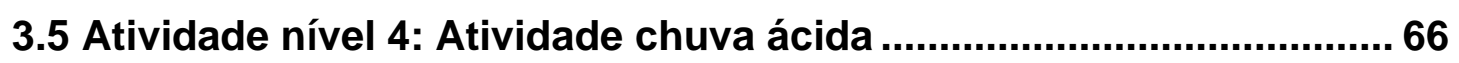

3.6 Atividade nível 4: Atividade sobre conservação da massa............... 72

3.7 Análise da formação do espírito científico de alguns alunos ............ 77

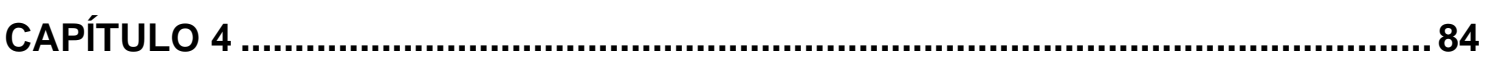

4 ANÁLISE DA EVOLUÇÃO DAS RESPOSTAS ELABORADAS PELOS ALUNOS DURANTE AS ATIVIDADES DE NÍVEL 5 84

4.1 Apresentação das respostas elaboradas pelos alunos durante as atividades de nível 5 . 85

4.1.1 Apresentação das respostas elaboradas pelo Grupo 1 nas atividades de nível 5. 85

4.1.2 Apresentação das respostas elaboradas pelo Grupo 2 nas atividades de nível 5 
4.1.3 Apresentação das respostas elaboradas pelo Grupo 4 nas atividades de nível 5 95

4.1.4 Análises das respostas frente à formação do espírito científico .. 99

4.1.5 Considerações sobre a aplicação da estratégia investigativa de nível 5 e possibilidades de estudos futuros. 102

CAPÍTULO 5 104

5 A FORMAÇÃO CONTINUADA E A PESQUISA-AÇÃO 104 CAPÍTULO 6 106

6 CONCLUSÕES E CONSIDERAÇÕES FINAIS 106

REFERÊNCIAS BIBLIOGRÁFICAS Erro! Indicador não definido.

APÊNDICE A. 115

Atividade investigativa Dimensão do átomo 115

APÊNDICE B - Densidade dos sólidos 116

APÊNDICE C- Atividade nível 4: chuva ácida 117

APÊNDICE D - Cronograma Experimental 119

APÊNDICE E - Redação 123

APÊNDICE F - Roteiro entrevista 124

ANEXO A - Questionário inicial 125

ANEXO B 126

ANEXO C - Atividade investigativa nível 4, conservação da massa. 129

ANEXO C - Atividade investigativa nível 4, conservação da massa. 130 


\section{CAPÍTULO 1}

\section{INTRODUÇÃO}

Neste capítulo serão realizados um breve resumo de como a educação evoluiu ao longo dos anos no Estado de São Paulo e uma contextualização da problemática do ensino médio noturno. Serão apresentadas a Teoria de Gaston Bachelard (1996) utilizada como referencial teórico, a abordagem investigativa como aliada para promover indícios de formação do espírito científico em aulas de Química e uma revisão sobre a pesquisa-ação no Brasil e no mundo.

\subsection{Aspectos educacionais}

O ensino tradicional ainda é aplicado na maioria nas escolas do país, apesar das diversas críticas a este sistema de ensino. Segundo Leão (1999), na escola tradicional, o ensino é realizado de forma cumulativa e adquirido pelo estudante por meio da transmissão dos conhecimentos a ser realizada pela escola ou docente. Dessa forma, espera-se que o estudante memorize a matéria e consiga reproduzilas ao final do bimestre, sendo um sujeito passivo dos processos de ensino e de aprendizagem.

Com a divulgação das Diretrizes Curriculares Nacionais (BRASIL, 2013), observou-se que as condições atuais do Ensino Médio estão aquém de atenderem as necessidades dos estudantes, seja para o exercício da cidadania ou para o mercado de trabalho. Neste sentido, a preocupação com o aprendizado do aluno para que ele possa utilizar o saber adquirido na vida, após o período escolar, pode ser encontrado nas Diretrizes Curriculares Nacionais Gerais da Educação Básica (BRASIL, 2013, p. 181):

Nessa perspectiva, são também importantes metodologias de ensino inovadoras, distintas das que se encontram nas salas de aula mais tradicionais e que, ao contrário dessas, ofereçam ao estudante a oportunidade de uma atuação ativa, interessada e comprometida no processo de aprender, que incluam não só conhecimentos, mas, 
também, sua contextualização, experimentação, vivências e convivência em tempos e espaços escolares e extraescolares, mediante aulas e situações diversas, inclusive nos campos da cultura, do esporte e do lazer.

Pensando na dificuldade em fazer o aluno compreender, se aproximar dos conceitos relacionados à Ciência e transpor esses conhecimentos para o seu cotidiano, o Estado de São Paulo criou, em 2008, a Proposta Curricular do Estado de São Paulo que trazia uma mudança de estratégia para o ensino das Ciências da Natureza. Esta proposta de currículo pode ser considerada pouco madura quando comparado a outros países como, por exemplo, os Estados Unidos, que possuem o documento National Research Council (1996) que aplica os tópicos das Ciências por grandes áreas utilizando a investigação como estratégia de ensino. O documento proposto pelo Governo do Estado de São Paulo apenas indica os tópicos dos conteúdos de Química que os professores deveriam trabalhar e, em alguns momentos, utilizam o termo investigação durante o desenvolvimento do componente curricular, sem explicação para o professor de como seria o uso da estratégia investigativa em sala de aula.

No ano de 2011, a Proposta Curricular foi reformulada e passou a ser chamada de Currículo do Estado de São Paulo (SÃO PAULO, 2011). O documento foi reformulado fornecendo algumas explicações de como os conteúdos evoluem ao longo dos três anos do Ensino Médio e como se dão as articulações de conteúdo com o ano de ensino.

O Currículo (SÃO PAULO, 2011) é dividido em quatro fascículos, cada um voltado para uma grande área: Matemática, Linguagens e Códigos, Ciências da Natureza e Ciências Humanas. Estes cadernos são iniciados com indicações do movimento que o professor deve realizar para a implantação do Currículo na sala de aula, após um breve apanhado sobre o aprender a aprender e mobilizar o aluno com um novo formato de aprendizagem, no qual espera-se que ele se torne mais participativo do processo de ensino-aprendizagem. A partir da introdução, cada grande área é subdividida pelas disciplinas que a contemplam. Para cada disciplina são apontados o bimestre, o tema, o conteúdo geral e os conteúdos específicos a serem trabalhados naquele bimestre, apresentando a trajetória a ser trilhada pelo professor. 
Como material complementa para a implantação do Currículo do Estado de São Paulo, o professor recebe um caderno bimestralmente com sugestões de como cada aula deve ser aplicada e as habilidades e competências que são esperadas a serem atingidas naquela aula, porém, esse material não é engessado, pois o professor tem a liberdade de utilizar os recursos que the convém. Para apoiar o professor, foi criado o caderno do aluno, cujo material é entregue a cada bimestre, e dividido por situações de aprendizagem que compõem temáticas em que são desenvolvidos os conteúdos. Ao início da situação de aprendizagem é apresentado um texto que tem a finalidade de problematizar e levantar os conceitos prévios do aluno. A partir da problematização, são apresentados exercícios e, sempre que possível, é apresentado um roteiro de experimentação com materiais do dia a dia. Para a avaliação do desenvolvimento do aluno sobre o tema, o professor tem a liberdade de escolher como ela será realizada.

Outra evolução do Currículo ocorreu em agosto de $2020 \mathrm{com}$ a homologação do Currículo Paulista, alinhado com a Base Nacional Curricular Comum (BNCC), a qual apresenta as aprendizagens essenciais que todos os estudantes devem desenvolver. Nessa direção, o novo Currículo pretende tornar o Ensino Médio mais interessante para os estudantes, propondo abordagens pedagógicas mais práticas, interativas, inclusivas e diversificadas. Para tanto, serão aprofundadas as aprendizagens do Ensino Fundamental, entre as quais podem ser citadas: investigação e pesquisa; análise crítica e argumentativa; abstração; reflexão; resolução de problemas dentre outras.

As aprendizagens essenciais definidas no Currículo Paulista do Ensino Médio estão organizadas nas seguintes áreas: Linguagens e suas Tecnologias, Matemática e suas Tecnologias; Ciências da Natureza e suas Tecnologias; Ciências Humanas e Sociais Aplicadas. Neste Currículo, a área de Ciências da Natureza e suas Tecnologias pretende promover 0 aprofundamento e a ampliação dos conhecimentos explorados no Ensino Fundamental, tratando a investigação como forma de protagonismo do estudante na aprendizagem, o que the permite analisar fenômenos, fazendo previsões. Dessa maneira, possibilita que o estudante amplie a compreensão sobre a vida e o meio que o cerca, bem como a capacidade de refletir, argumentar, propor soluções e enfrentar desafios pessoais e coletivos, locais e globais. 
Para professores que já estão na rede e habituados com o ensino tradicional, mudar de estratégia de uma hora para outra não é tarefa fácil, o que demanda tempo e apropriação de novas estratégias de ensino como, por exemplo, a abordagem investigativa.

Com a reformulação do currículo, espera-se um movimento do professor em rever a prática docente e estar aberto a testar novas estratégias de ensino, além de buscar fazer com que o aluno participe dos processos de ensino e de aprendizagem.

\subsection{A problemática do Ensino Médio no período noturno}

A partir da promulgação da Constituição Federal de 1988, era pretendida a universalização do Ensino Médio no Brasil. O texto da Constituição foi alterado pela Emenda Constitucional no 14/1996, que estabeleceu a "progressiva universalização do ensino médio gratuito" (BRASIL, 1996). Posteriormente, o Plano Nacional de Educação estabeleceu, no ano de 2001, a ampliação de atendimento a 100\% da demanda do Ensino Médio, por um período de dez anos, de acordo com Sousa e Portela de Oliveira (2008).

Para Rodrigues (1995), a universalização do acesso oportunizada pelas políticas públicas e a generalização dos cursos noturnos representou, ao mesmo tempo, a democratização do acesso à escola e o fortalecimento de mais uma divisão da mesma. Neste sentido, ficou estigmatizada a divisão da escola em ensino diurno e ensino noturno, onde o ensino diurno era considerado de qualidade e o ensino noturno foi associado à preparação de futuros trabalhadores, porém, com pouco valor intelectual e profissional.

Dessa forma, são mobilizadas pela equipe escolar formas e práticas de ensino "menos exigentes", com a finalidade de haver a permanência desses alunos na escola. Estes alunos possuem uma flexibilidade de entrada no turno escolar, aceitando-se seus atrasos, pois, muitas vezes, sua jornada de trabalho encerra-se após o horário da primeira aula do turno.

Apesar dessas "facilidades" encontradas pelos alunos trabalhadores, Sousa e Portela de Oliveira (2008) destacam alguns fatores para a desmotivação dos alunos no ensino noturno. O primeiro fator é o cansaço atribuído pelos alunos devido à monotonia das aulas centradas no professor e à exaustão devido ao trabalho durante o dia. Os alunos possuem o desejo de que o Ensino Médio noturno 
proporcione condições para a realização posterior de um curso superior. Alguns alunos relatam um sentimento de inferioridade devido à comparação com o turno diurno e a noção de que o contexto escolar não conspira a favor: escola pior; professor menos motivado.

Segundo Abramovay (2003), os alunos não gostam da escola e não se reconhecem nela, relatando críticas sobre os procedimentos de gestão, as faltas e 0 desinteresse dos professores e a precariedade das instalações. Também é vista como um ambiente desorganizado, com inúmeras regras, sendo estas rapidamente esquecidas dependendo do momento. Estas regras são enxergadas pelos estudantes como autoritárias e são burladas pelos alunos com a finalidade da construção de uma nova relação que faça sentido para o próprio.

Uma consequência desse contexto geral é a evasão escolar. As taxas de evasão escolar em cursos noturnos de Ensino Médio podem ser um dos fatores resultantes do fracasso escolar, mostrando a situação do Ensino Médio brasileiro. A investigação dos fatores que determinam a evasão à noite não deve ser delimitada apenas em relação aos estudantes e, sim, às questões como a falta de recursos que colaboram com o trabalho do professor no período noturno, a inconveniência do horário de funcionamento da escola até às 23 horas e métodos de ensino que não contemplam os interesses dos alunos.

Alguns estudos como de Zainko e Pinto de Pauli Bettega (2007) sobre o Ensino Médio noturno mostram que a evasão ocorre devido a uma parte desse alunado estar incorporada precocemente no mercado de trabalho. Muitas vezes, o jovem necessita trabalhar devido ao baixo salário do responsável pela família, o que o "obriga" a trabalhar cedo. O jovem, ao ser incorporado no mercado de trabalho como mão de obra mais barata, encontra emprego com facilidade, contribuindo com o orçamento familiar, culminando no abandono escolar.

Neste sentido, Rodrigues (1995) conclui que, a escola de Ensino Médio noturno, ao igualar o aluno trabalhador com o não trabalhador, afirma a sua natureza teórica livre das experiências diárias do trabalho e, ao mesmo tempo, oculta a identidade e a necessidade do aluno trabalhador. Desse modo, o fato de o aluno noturno receber um ensino defasado em relação aos demais turnos mostra-se como sendo determinante nas dificuldades que ele irá enfrentar, tanto para prosseguir no ensino superior como para obter uma posição favorável no mercado de trabalho. 
Diante deste complexo sistema educacional, percebe-se a necessidade de um olhar crítico, porém reflexivo voltado para esse alunado, que merece tanto quanto os alunos não trabalhadores, um ensino digno e de qualidade voltado aos seus interesses e que faça sentido tanto para sua vida escolar como no trabalho.

\subsection{Referencial teórico: Gaston Bachelard}

Gaston Bachelard nasceu em 27 de junho de 1884 e faleceu em 16 de outubro de 1962, foi professor de Física e Química e, aos 35 anos, iniciou os estudos de Filosofia, o qual posteriormente também lecionou a disciplina. Sua obra é dividida em duas fases: diurna e noturna, sendo que as obras referentes à fase diurna versam sobre epistemologia e história da Ciência, enquanto a outra fase apresenta característica poética. Neste trabalho será utilizado apenas algumas obras da fase diurna tais: A Formação do Espírito Científico (1996), o Novo Espírito Científico (2000).

Para Bachelard, nada na ciência é definitivo e, em seus livros, o filósofo discute novos modelos de estudo para a evolução da ciência. Em sua teoria do conhecimento, dentre outras questões, trata sobre obstáculos epistemológicos que são entraves à evolução do conhecimento e que causam estagnação, inércia ou regressão. Em relação à formação do espírito científico, o autor sugere que se deve reformular suas crenças e ideias constantemente. Em sua obra, o filósofo afirma que o indivíduo que possui um espírito científico sabe formular problemas, portanto, as crises de crescimento do pensamento implicam em uma reorganização do saber.

Em A formação do espírito científico, o autor defende que, para atingir o espírito científico, o indivíduo deve passar por três estágios os quais ele intitula como Lei dos três estados:

1. Estado Concreto: situação em que o sujeito tem apego às imagens do fenômeno, exaltando a natureza;

2. Estado Concreto-abstrato: o sujeito ainda necessita de imagens como apoio para a explicação de fenômenos abstratos;

3. Estado abstrato: o espírito adota informações do espaço estudado, porém, sem ligação com a experiência primeira, inicialmente chamada de estado concreto.

Para que sejam alcançadas essas três etapas para a formação do espírito científico é necessário vencer alguns obstáculos, os quais ele nomeia como 
obstáculos epistemológicos. Bachelard (1996) define esses obstáculos como ações que causam estagnação, inércia ou regressão da ciência. $O$ epistemólogo aponta sete obstáculos: a experiência primeira, o conhecimento geral, o obstáculo verbal, o conhecimento unitário e pragmático, o obstáculo substancialista, o obstáculo animista e o conhecimento quantitativo.

A experiência primeira é aquela imediata. Está acompanhada de sentimentos, impulsos e nascem dos fatos vistos, observados no mundo. Um exemplo de experiência primeira, o autor destaca no trecho a seguir: "Mas, para provar claramente que o que existe de mais imediato experiência primeira somos nós mesmos, nossas surdas paixões, nossos desejos inconscientes (...)" (Bachelard,1996, p. 57).

O segundo obstáculo epistemológico discutido pelo filósofo é o conhecimento geral. Trata-se do processo mais usado pelo senso comum ou espírito pré-científico que, dos fatos observados, tira leis gerais aplicáveis a outros fatos semelhantes - como em um círculo -, é a "atividade do pensamento empírico inventivo" (Bachelard, 1996, p. 76).

Outro obstáculo apresentado pelo filósofo é o obstáculo verbal, sendo utilizado como exemplo a esponja. A metáfora da esponja representa uma imagem generalizada com explicações rápidas, fazendo com que o sujeito esteja satisfeito com a resposta, não questionando o pensamento. Dessa forma, a palavra esponja era utilizada para exemplificar o "armazenamento" de alguma substância comparando com as propriedades da esponja. Para o indivíduo ainda no estado concreto, essa explicação por si só basta, não necessitando de demais argumentações, como exemplificado no trecho a seguir: "a expressão "o ferro é uma esponja do fluído magnético" é, portanto, uma metáfora que foge à verdade" (Bachelard, 1996, p.97)

O quarto obstáculo epistemológico é o conhecimento unitário e pragmático. O conhecimento unitário é representado por generalidades e busca a unidade porque confere certeza. O pragmatismo ocorre em busca de uma utilidade, sendo útil, pode ser utilizado como um princípio de explicação. O sujeito ainda pré-científico concorda pois, para ele, é real, percebe-se a aplicação, resultando assim em uma falsa impressão de que foi encontrado um porquê para o problema, como pode ser observado no trecho a seguir: 
(Buffon) quer julgar os objetos apenas pelas relações de utilidade ou de familiaridade que têm conosco; e sua grande razão para isso é que nos é mais fácil, mais agradável e mais útil considerar as coisas em relação a nós do que sob qualquer outro ponto de vista. (BACHELARD,1996, p. 116).

O próximo obstáculo delineado pelo filosofo é o substancialismo, o qual é encontrado na forma de diversos adjetivos para a mesma substância. Bachelard (1996) denomina: "um dos sintomas mais claros da sedução substancialista é o acúmulo de adjetivos para um mesmo substantivo" (1996, p.140). Neste sentido, o filosofo discute que a substancialização de uma qualidade pode entravar os futuros progressos do pensamento científico e faltar para o espírito científico a crítica e o pensamento teórico. Sendo assim, o espírito científico tende a diminuir esses adjetivos.

O obstáculo animista é criticado pelo autor pois essas generalizações são inconscientes e ao mesmo tempo são convincentes. O espírito pré-científico se utiliza dessas comparações dando qualidades de seres vivos a seres inanimados como pode ser observado no trecho abaixo:

O metal tirado da terra da qual já não recebe alimento algum, pode muito bem ser comparado nesse estado ao homem velho, decrépito... a natureza conserva a mesma circulação de nascimento e morte tanto nos metais como nos vegetais e nos animais (BACHELARD,1996, p.194).

Esse tipo de explicação citada acima acaba convencendo o sujeito com espírito pré-científico, satisfazendo um falso esclarecimento.

O último obstáculo, o conhecimento quantitativo, Bachelard (1996) refere-se ao fato do cientista considerar previamente a realidade, o conhecimento imediato, pois ela oferece certezas imaturas que, ao invés de ajudar, atrapalham o desenvolvimento do conhecimento. No trecho: "é preciso refletir para medir, em vez de medir para refletir" (1996, p. 262), o autor mostra a preocupação com a necessidade de pensar, refletir como será realizado o experimento, as variáveis que podem ser encontradas e só assim, a partir destes detalhes previstos, é que se realiza um experimento ou uma medida. $O$ indivíduo com o espírito ainda não formado apenas realiza o experimento e se preocupa com o dado obtido e não como 
ele foi obtido e nem leva em consideração o erro que pode estar envolvido durante um experimento ou uma medição.

Neste sentido, o autor mostra em seu livro O novo espírito científico (2000) a importância da geometrização do cálculo matemático e, somente depois desses parâmetros, que é realizado o experimento. Portanto, o novo espírito científico tem como característica técnicas experimentais que revelam a realidade científica, sendo assim, a realidade é pensada por meio da técnica - o contrário das ciências anteriores que ocorre do abstrato - teórico-matemático ao concreto observado experimentalmente.

Nesta perspectiva, Bachelard (1996) aponta a necessidade de refletir sobre o fazer ciência e a consciência do erro, aceitando possíveis falhas intelectuais. $O$ filósofo destaca que o erro não é ruim e, sim, que o erro pode ser positivo e útil, desde que o sujeito se desvencilhe do orgulho e de certezas gerais, pois isso entrava o questionamento do porquê do erro. Um exemplo disso é observado durante as aulas marcadas pela autoridade do professor, sendo soberano na sua explicação, não permitindo o aluno questioná-lo como Bachelard destaca no trecho a seguir:

\footnotetext{
"Os professores, sobretudo na multiplicidade incoerente do ensino secundário, apresentam conhecimentos efêmeros e desordenados, marcados pelo signo nefasto da autoridade. Os alunos assimilam instintos indestrutíveis". (BACHELARD, 1996, p. 299).
}

Dessarte, Bachelard (1996) aponta como um dos obstáculos no ensino de ciências o fato do professor não compreender por que o aluno não aprende. $O$ filósofo critica duramente os professores e sua metodologia de ensino que resultam em um aluno que apenas reproduz, não questiona e não critica.

Para ensinar o aluno a inventar, é bom mostrar-lhe que ele pode descobrir. É preciso inquietar a razão e desfazer os hábitos do conhecimento objetivo. Deve ser, aliás, a prática pedagógica constante. (BACHEARD, 1996, p 303.)

Nesse trecho, o filósofo retrata a necessidade de o professor refletir sobre sua prática para ensinar o aluno a pensar. Além disso, repensar sobre o que está sendo ensinado e não apenas realizar o mais do mesmo copiando a matéria exposta na lousa. Espera-se uma mudança de atitude do docente, saindo do ensino 
tradicional centrado no professor, esperando que o aluno absorva todo conteúdo e, ainda, compreenda ou critique algo. Muitas vezes, esse "aprendizado" garante ao aluno a mecanização de certos conceitos, o que passa a impressão aos professores de que o aluno compreendeu a matéria. Os professores não percebem que os alunos possuem conhecimentos prévios e suas próprias crenças, dessa forma, os conhecimentos "adquiridos" não fazem sentido para o aluno. Por isso, o professor espera que aluno compreenda, por exemplo, um experimento microscopicamente sendo que, para o aluno, a atividade não faz sentido. O seu espírito científico ainda não foi despertado e cabe ao docente mostrar os caminhos para a evolução do mesmo.

De acordo com o exposto acima, os textos de Gaston Bachelard têm grande relevância na área da educação, ajudando educadores a repensarem o ensino de ciências e a sua prática. Deste modo, pode-se ser observadas algumas pesquisas que utilizam o filósofo como referencial teórico em várias áreas do conhecimento. Um exemplo destes trabalhos no campo teórico é o trabalho de Dos Reis, Kiouranis e Da Silveira (2017), que realizaram pesquisas sobre o ensino de teoria atômica na área científica com foco epistemológico. $O$ trabalho discute a história da filosofia da ciência aos olhos de Bachelard e compara estes dados com o ensino tradicional, onde o ensino ocorre por meio de memorização de fatos, nomes e datas, não sendo um ensino científico onde há a construção do. Considerando a importância da aprendizagem do conceito de átomo para o ensino de Química e de acordo com os fundamentos de Bachelard, é chamada a atenção para problematizar o conceito dos modelos atômicos a fim de que os alunos possam compreender criticamente como a ciência é construída e como os conhecimentos são modificados, desconstruindo um conhecimento anterior para construir o novo. Os autores ressaltam a necessidade de abordagens do contexto histórico e epistemológico no ensino de ciências, tanto na formação de professores quanto na educação básica.

Da Fonseca (2008) realiza discussões metodológicas sobre o livro $O$ novo espírito científico e sugere que o professor utilize, em conjunto com a sua prática, a pesquisa, pois sempre aprenderá para melhor ensinar. Por consequência, o trabalho visa desenvolver ações formativas que contemplem a prática social e histórica. Essas reflexões visam a articulação teoria-prática com a finalidade da compreensão da pesquisa como uma atividade criativa. A partir das reflexões, espera-se a 
compreensão do fazer científico, da prática interdisciplinar, da articulação teoriaprática e do aprendizado integrado entre pesquisa/ensino. A autora conclui que é necessária uma prática científica, crítica e reflexiva tanto no campo da Pedagogia como na formação docente.

Da Ronch, Danyluk e Zoch (2016) realizaram reflexões acerca da epistemologia de Bachelard frente à formação do espírito científico e à formação do novo espírito científico aplicada ao ensino de ciências e à prática docente. Para a formação do espírito científico os autores relatam que deve haver uma problematização do ensino sendo capaz de proporcionar aos estudantes um ensino reflexivo e crítico. Os autores sugerem, ao final do trabalho, que seja realizada pelo professor uma mediação entre os conhecimentos e as crenças que os estudantes possuem e os estudos teóricos-científicos realizados em sala de aula.

No campo teórico-prático, o trabalho de Gomes e Oliveira (2007) identificou os obstáculos epistemológicos em alunos de oitavo ano do Ensino Fundamental e de primeiro ano do Ensino Médio, referentes ao ensino de atomística, comparando o aprendizado com o que foi encontrado em materiais didáticos utilizados. Para a realização da pesquisa, utilizaram três perguntas, sendo a primeira objetiva e as outras duas abertas. Para as questões abertas foi solicitado que os alunos desenhassem a fim de observar quais eram as concepções dos alunos sobre os modelos atômicos. Os autores coletaram um total de 291 questionários, sendo que 156 eram de alunos do primeiro ano e 135 alunos do oitavo ano. Após a aplicação de atividades para verificar quais obstáculos epistemológicos são encontrados no ensino de atomística, foi possível verificar a existência de alguns deles em ambos os anos analisados. Foi realizada uma mudança de material e abordagem e, ainda assim, verificaram a presença de obstáculos epistemológicos nas respostas dos alunos, como o uso do modelo planetário. Os autores chamam a atenção para a importância do professor neste momento visto que o modo como ele transmite o conteúdo influenciará na forma como o aluno compreende o conteúdo.

Kasseboehmer e Ferreira (2013a) realizaram a aplicação de problemas investigativos em aulas teóricas de Química visando compreender a influência do ambiente escolar na formação do espírito científico. Os autores aplicaram atividades em duas escolas públicas e em uma escola particular e encontraram resultados diferentes. Foram utilizadas onze atividades de investigação que envolviam alguns 
dos conceitos trabalhados pelos professores de ambas as escolas. Os resultados obtidos na escola pública foram de baixo rendimento em relação aos acertos sobre conceitos químicos, porém possuíam maior liberdade de pensamento, comparados aos alunos do colégio particular que apresentaram respostas coerentes, todavia, utilizavam a internet como meio de obter as respostas, portanto, não refletiam sobre a atividade. Os autores concluem que na escola particular os alunos obtiveram um bom rendimento, mas demonstraram menor satisfação em participar e menor liberdade para ousar em suas propostas. Já os alunos da escola pública sentiram maior satisfação em conviver com o projeto e mostraram maior liberdade com a criação de ideias, entretanto foram prejudicados por problemas conceituais. Os autores finalizam com a seguinte crítica: "isso significa que a escola e os professores precisam refletir sobre sua importância e sua função, buscando ser um espaço de problematização" (Kasseboehmer e Ferreira, 2013, p. 163).

Em outro trabalho, Kasseboehmer e Ferreira (2013b) aplicaram seis atividades investigativas em aulas teóricas de Química com alunos de primeiro ano do Ensino Médio e alunos de primeiro ano de uma escola particular a fim de conhecerem possíveis concepções alternativas. O tema da atividade foi sobre odores e para a sua realização foram apresentadas quatro questões abertas aos alunos. As respostas foram classificadas em coerentes, pouco coerentes e hipóteses não coerentes. Observando as respostas dos alunos em ambas as escolas, os autores notaram a presença de concepções alternativas, tais como: "se fundem", "se juntam". Este trabalho, ainda segundo os autores, permitiu conhecer possíveis concepções alternativas e incentivar a participação dos estudantes por meio da proposição de explicações para fenômenos científicos. Segundo Lôbo (2008), é necessária a discussão de aspectos relativos ao ensino de Química e à formação do educador químico. Lopes (1993) apresenta questionamentos a fim de colaborar com a reformulação do ensino de ciências e especialmente da química.

A partir da revisão bibliográfica acima, pode ser observado que a maioria dos textos está voltada à reflexão, discussões teóricas e poucos artigos propõem ações práticas das teorias de Gaston Bachelard. Dessa forma, observa-se a relevância de utilizar o filósofo como referencial teórico. 


\subsection{0 uso da estratégia investigativa}

O laboratório de ciências tem sido usado há muito tempo para finalidades didáticas, porém, desde o início do século $\mathrm{XX}$, era debatido sobre qual o papel do uso de laboratórios nas aulas de ciências. A partir da década de 1920, as atividades de laboratório passaram a ser confirmatórias, ou seja, apenas para a reprodução das informações aprendidas com o professor ou o livro. Essa rotina permaneceu até a década de 60, quando foram iniciadas as discussões sobre o papel do trabalho de laboratório. No sentido de utilizar o laboratório de uma forma diferente, Allen, Barker e Ramsden (1986) relatam, em seu trabalho, a conversão de um experimento tradicional em um experimento investigativo guiado pelo professor onde 0 aluno descobre o conceito por si mesmo usando seus dados obtidos em laboratório. Hofstein e Lunetta (1982) apontam algumas questões que poderiam dificultar o uso pedagógico do laboratório. São eles:(1) poucos professores nas escolas possuem habilidades para usar o laboratório de maneira eficaz;(2) o foco apenas na atividade laboratorial leva a uma concepção estreita de Ciência; (3) muitas experiências realizadas nas escolas são simples; (4) o trabalho realizado no laboratório das escolas costuma ser distante e não relacionado com os interesses das crianças.

Atualmente, ainda são encontrados alguns fatores citados acima e que entravam o uso do laboratório como um recurso no qual o aluno possa aprender fazendo ciência. Em muitas escolas há o problema da falta de laboratórios, de reagentes e até de profissionais que se sintam capacitados a utilizá-lo com muitos alunos. Outro problema comum é a falta de tempo para que o professor consiga preparar o local para receber seus alunos para o início da atividade.

Nessa perspectiva, uma forma de contornar o problema de sobrecarga do professor durante a preparação do laboratório para realização de atividade prática seria adotar a estratégia investigativa.

A estratégia investigativa é utilizada para se referir ao aprendizado de ciências em salas de aula ou laboratórios e, a partir do seu uso, alunos e professores discutem ciência. Uma vantagem de trabalhar com estratégias investigativas é utilizar as atividades de laboratório nas quais os alunos podem interagir com materiais, elaborar modelos e entender a natureza que o cerca.

O uso desta estratégia propõe que o aluno seja um sujeito ativo no processo de aprendizagem onde, a partir de uma situação problema, ele é capaz de elaborar 
e testar hipóteses, alcançar conclusões, além de discutir entre os pares durante todo o processo, sendo possível, dessa forma, também aprender com o erro. Autores diferentes propõem níveis de abertura do experimento que se relacionem com os graus de liberdade oferecidos aos alunos na participação da resolução de problemas. Por exemplo, Pella (1961, p. 30) propõe cinco graus de liberdade para o trabalho do professor e do aluno descritos no Quadro 1 a seguir:

Quadro 1 - Níveis de abertura do experimento P - professor; E - estudante

\begin{tabular}{|c|c|c|c|c|c|}
\hline $\begin{array}{c}\text { Passos no } \\
\text { procedimento }\end{array}$ & Nível 1 & Nível 2 & Nível 3 & Nível 4 & Nível 5 \\
\hline Problema & P & P & P & P & E \\
\hline Hipóteses & P & P & P & E & E \\
\hline Plano de trabalho & P & P & E & E & E \\
\hline Experimento & E & E & E & E & E \\
\hline Dados experimentais & E & E & E & E & E \\
\hline Conclusão & P & E & E & E & E \\
\hline
\end{tabular}

Fonte: Adaptado de PELLA, 1961, p.31.

De acordo com os níveis propostos por Pella (1961), o nível 1 e 2 de abertura pode ser considerado o experimento usualmente aplicado em sala de aula. Este tipo de experimentação pode ser chamado de confirmatório, o qual o professor apresenta a metodologia pronta, o aluno realiza o experimento, coletando os dados, e a conclusão final pode ser dada pelo professor ou realizada em conjunto com a sala. A partir dos níveis 3 e 4, pode ser observado maior grau de liberdade, podendo-se dizer que, a partir deste nível, o experimento é investigativo. $O$ aluno deve elaborar o plano de trabalho, realizar o experimento, coletar os dados experimentais e elaborar uma conclusão, tornando o aluno um sujeito ativo no processo investigativo. Já no nível 5, o aluno possui o maior grau de liberdade, propondo desde um problema, desenvolvendo todas as etapas citadas no Quadro 1, até a elaboração da conclusão. 
Para Tamir (1977), o trabalho experimental investigativo apresenta as seguintes características: (1) deve ser um meio para explorar as ideias dos alunos e desenvolver a sua compreensão conceitual; (2) deve ser sustentado por uma base teórica prévia informadora e orientadora da análise dos resultados; (3) deve ser delineado pelos alunos para possibilitar um maior controle sobre sua própria aprendizagem, sobre as suas dificuldades e de refletir sobre o porquê dessas atividades para ultrapassá-las.

Tobin (1990) sugeriu que um aprendizado significativo é possível em laboratório se os alunos tiverem a oportunidade de manipular materiais para que eles construam seus próprios conhecimentos sobre fenômenos e relacioná-los a conceitos científicos.

Neste sentido, Hofstein e Lunetta (2003) explicam que a investigação se refere à diversas maneiras pelas quais os cientistas estudam o mundo, propõem ideias, explicam e justificam proposições com base em evidências derivadas do trabalho científico. Eles também se referem às formas nas quais os alunos podem investigar o mundo, propor ideias, explicar e justificar asserções baseadas em evidências e, no processo, "sentir" o trabalho de um cientista.

Além desses fatores citados anteriormente, outra particularidade sobre a aplicação de atividades experimentais investigativas é o fato do professor poder conduzir a atividade por meio de questionamentos com a finalidade da análise do erro, sendo possível refletir sobre ele e, assim, possibilitar ao aluno realizar uma nova tentativa. No trabalho de Carvalho, Vannucci e Barros (1998), os autores sugerem iniciar essa reflexão com a explicação do aluno para entender o seu pensamento e, por meio de perguntas que o levem a conflitos cognitivos, são criadas condições para que ele mesmo possa superar o erro. De acordo com Carvalho (2013), quando o erro é trabalhado em sala e o aluno percebe o seu erro, ele aprende muito mais do que se estivesse em uma aula expositiva seguindo o raciocínio do seu professor. Dessa forma, cabe ao professor ajudá-lo a preencher as lacunas aparentes durante o momento de questionamento, transformando-os em situações privilegiadas de novas aprendizagens.

O uso da estratégia investigativa foi utilizado por Cuevas, Lee, Hart e Deaktor (2005) em escolas primárias de terceiros e quartos anos do Ensino Fundamental I (anos iniciais), no Fundamental II (anos finais) nos $7^{\circ}$ e $8^{\circ}$ anos. Geier, Blumenfeld, 
Marx, Krajcik, Fishman, Soloway, Clay-Chambers (2008), também aplicaram em escolas de Ensino Médio Sesen. Tarhan (2013), em turmas de ensino superior e Goodey e Talgar (2016) mostraram a abrangência da aplicabilidade da estratégia.

Os estudos apresentados acima indicam que a participação em atividades de pesquisa contribuiu para a aprendizagem de conceitos científicos e promoveu a habilidade de investigação. Ruiz-Primo, Li, Tsai e Schneider (2010) estudaram a qualidade das explicações científicas de alunos do Ensino Fundamental que participaram de atividades de investigação. Os autores descobriram que existe uma correlação positiva entre a qualidade de suas explicações e seu desempenho, embora pareça haver poucas oportunidades para os alunos construírem explicações científicas sobre fenômenos científicos, mesmo em salas de aula de pesquisa.

Pesquisas também indicam que a mudança na prática docente não é trivial. Herrington, Yezierski,Luxford e Luxford (2011) acompanharam dez professores que trabalhavam com a abordagem baseada em investigação. Os autores descobriram que, quanto mais o professor se aproxima da abordagem investigativa às suas crenças pessoais, mais ele se sente confortável para aplicar a estratégia. Os autores observaram também que há resistência de alguns professores em usar a ciência investigativa, o que é plausível no sentido de que eles teriam de mudar completamente suas práticas passadas e atuais para incorporarem essa nova abordagem. Isso mostra que a implementação do método baseado em investigação na rotina da sala de aula implica ações complementares, incluindo a produção de material didático e a capacitação de professores.

Nesta perspectiva, Szalay e Tóth (2016) descreveram ações que possibilitam a implementação da abordagem baseada em investigação no cotidiano da sala de aula a partir da modificação das atividades tradicionais. Segundo os autores, os alunos se beneficiam quando a abordagem baseada em pesquisa é empregada no ensino. Ainda neste sentido, Artigue (2013) realiza uma correlação com teorias já fundamentadas e a aplicação de investigação na matemática. Ao final do trabalho, são elencadas dez preocupações que os professores devem estar atentos antes de se aplicarem atividades que utilizem investigação.

No Brasil, Carvalho e Lima (1999) mostram que as atividades de caráter investigativo que possuem uma questão problematizadora ao mesmo tempo despertam a curiosidade do aluno sobre os fatos relevantes em relação ao 
fenômeno estudado, podendo levantar suas próprias teorias ou hipóteses. Suart, Marcondes e Carmo (2009) observaram que as atividades experimentais investigativas podem contribuir para o desenvolvimento cognitivo dos estudantes, pois eles têm a oportunidade de participar de todas as etapas de investigação. A exemplo, propor hipóteses para o problema, analisar dados e elaborar conclusões, participando da construção de um conceito ou conhecimento científico. Kasseboehmer e Ferreira (2013) aplicaram em escolas públicas atividades investigativas para estudarem as condições da formação do espírito científico e seus estudos mostram que, na escola pública, os alunos participavam mais e tinham uma maior liberdade para elaborar hipóteses.

Considerando o número crescente de estudos sobre a abordagem baseada em investigação, torna-se importante compreender as contribuições da abordagem baseada em investigação em condições favoráveis e desfavoráveis.

\subsection{A Pesquisa-Ação no Brasil e no mundo}

No Brasil são encontrados poucos trabalhos referentes à pesquisa-ação relacionados à educação. Foram pesquisados trabalhos referentes a esse tema $\mathrm{e}$ foram encontradas apenas duas pesquisas, nas quais o pesquisador é o professor da turma. Um dos trabalhos foi o de Felcher, Ferreira e Folmer (2017), voltado para a Matemática e uso de novas ferramentas, como o Facebook, para alunos de Ensino Fundamental. Este trabalho obteve como resultado melhores índices de aproveitamento na disciplina de Matemática, além de possibilitar novos aprendizados para o professor. O outro trabalho era de Reigada e Reis (2004), que envolveu alunos de seis a onze anos, com a proposta de criar nas crianças 0 cuidado com o meio onde vivem. Os autores acreditam que, a partir do trabalho realizado, foi possível tornar as crianças capazes de criarem soluções para problemas e, ao mesmo tempo, o professor mediador aprender sobre o meio natural, social e cultural em que seus alunos vivem, havendo um aprendizado mútuo.

Diferentemente desses dois trabalhos em que o professor era o pesquisador, Benite e Benite (2009) acompanharam o trabalho de 13 professores, sendo oito professores de química e cinco de biologia, em oito turmas de terceiro ano do Ensino Médio. Neste grupo há professores do ensino básico, professor em formação (continuada) e professores formadores de professores. Os dois primeiros grupos 
trabalharam uma atividade curricular de introdução à pesquisa em Educação em Ciências e o terceiro grupo foi o próprio pesquisador que coletou os dados da pesquisa. A proposta do trabalho foi utilizar o laboratório didático como estratégia de problematização dos conceitos químicos. Os autores acreditam que a aplicação do estudo permitiu, tanto aos alunos quanto aos professores, desenvolverem novas habilidades, tais como: criatividade e atitudes cooperativas entre os pares, além de valorizar a troca de informações entre eles.

Já no exterior, a pesquisa-ação é apresentada de uma forma mais organizada, ocorrendo em grupos de professores que são acompanhados periodicamente por grupos de pesquisa por um longo período. Solomon, Duveen e Scot (1992) acompanharam, durante 18 meses, professores que trabalharam sobre a natureza das ciências com alunos de Ensino Médio. Inicialmente, os professores ficaram apreensivos, porém, durante o desenvolvimento do estudo, ficaram admirados com a proposta e até sugeriram estratégias de ensino. Após o estudo, os professores puderam afirmar que seus alunos aprenderam com mais profundidade a natureza das ciências, além de apresentarem uma melhor compreensão do estudo das ciências na escola. Os autores afirmam que os dados ainda não são suficientes para afirmar a aprendizagem em longo prazo, portanto, serão realizados estudos posteriormente em alunos mais velhos.

O trabalho de Eilks e Ralle (2002) trata do desenvolvimento de novas abordagens para ensinar a natureza da matéria com mais eficiência. Esse projeto cooperativo foi realizado pela Universidade de Dortmund em várias instituições de Ensino Médio e escolas de gramática no oeste e norte da Alemanha, tendo os métodos de ensino adaptados à prática docente. Os professores participantes foram influenciados pelo processo e, ao refletirem sobre suas dificuldades, passaram a mudar seus métodos. Após três anos de trabalho utilizando esse método de pesquisa, os autores acreditam que há potencial para melhorar o ensino de química.

Eilks e Markic (2011) descrevem o potencial da cooperação a longo prazo entre educadores de ciências, professores de ciências e o desenvolvimento profissional contínuo dos professores. O grupo de trabalho inicial continha seis professores de química e, posteriormente, foi expandido para quinze professores de várias escolas. Foi observado pelos professores o desenvolvimento da capacidade reflexiva e os autores acreditam que a capacidade de mudança influencia na 
abordagem curricular e nos métodos de ensino aplicados. Além da melhora na prática docente, a cooperação e participação simultânea de professores e universidade em suas práticas de ensino intensificaram o contato entre escolas e universidade.

Towns, Kreke e Fields (2000) relataram a pesquisa-ação aplicada em alunos de Ensino Superior no curso de Química na disciplina de Termodinâmica. O trabalho se desenvolveu da seguinte forma: os alunos compareceram à três palestras, um laboratório de três horas de duração e uma "sessão de solução de problemas" uma vez por semana. Os alunos foram acompanhados durante um semestre, quando observado que as atividades realizadas em pequenos grupos criaram nos alunos um sentimento de comunidade, gerando confiança entre si. Dessa forma, o aprendizado é facilitado devido às relações interpessoais fortalecidas, ensinando um ao outro e compartilhando abordagens diferentes para solução de problemas. Os autores acreditam que este trabalho forneceu dados que podem explicar por que o uso de atividades em pequenos grupos é positivo, devido tais fatores como, por exemplo, aprendizado, conquistas e persistências.

Burmeister e Eilks (2012) acompanharam um grupo composto por dez professores de várias escolas secundárias no oeste da Alemanha. Eles se reuniam uma vez por mês e o desenvolvimento do plano de aula ocorreu durante um ano, tendo como tema escolhido plásticos e sustentabilidade. Professores e alunos consideraram que o foco foi além da aprendizagem do conteúdo de química, pois, existiam indicações de que os alunos aprenderam sobre questões de sustentabilidade e tornaram-se mais críticos em relação ao uso produtos químicos.

O objetivo do projeto era melhorar a qualidade da alfabetização ambiental e sustentabilidade no ensino de química, combinando a uma análise do ciclo de vida, com o uso da estratégia investigativa. Para apoiar o trabalho dos professores, cursos gratuitos de treinamento em serviço sobre desenvolvimento sustentável, uso das abordagens de análise do ciclo de vida e estratégia investigativa foram realizadas, na Finlândia, durante os anos de 2010 até 2012. O estudo sugere que as abordagens relacionadas à análise de ciclo de vida de um material e o uso da estratégia investigativa podem ser facilmente implementadas no ensino de química em todos os níveis escolares. Como o uso das duas estratégias aliadas ainda é novo, poderão ser incluídas formações de professores, bem como cursos que 
capacitem outros professores a utilizarem essa nova estratégia, difundindo essa inovação no ensino de química.

Marks e Eilks (2009) apresentam uma discussão sobre a pesquisa científica orientada para a alfabetização em ensino de química por meio do uso da abordagem Ciência, Tecnologia e Sociedade (CTS). O desenvolvimento da abordagem de ensino e os planos de aula aplicados no trabalho ocorreram por mais de oito anos em um projeto de pesquisa-ação participativa composto por um grupo de professores de várias escolas que trabalham diferentes questões envolvendo desenvolvimento curricular e pesquisa na sala de aula. Professores e alunos descreveram a situação de ensino como motivadora e intensa e, pela primeira vez, os alunos perceberam que a química apresentada na escola estava correlacionada com o dia a dia. Os autores consideram supor que a abordagem utilizada tem potencial para promover habilidades que promovam a alfabetização científica, além de alcançar discussão entre os alunos sobre questões de seu cotidiano e sociedade.

Ao comparar os dados no Brasil e no mundo, percebe-se a importância de se investir em formação de professores. Nos artigos citados anteriormente há a aproximação da universidade com a escola, fazendo com que o professores constantemente tenham contato com novas estratégias de ensino. Outro dado importante a ser ressaltado é que, em muitas vezes, os professores, ao serem convidados a refletirem sobre sua prática e aprender novas estratégias, ficam apreensivos, como no estudo apresentado por Solomon, Duveen e Scot (1992), chegando a desistirem de formações desse tipo. Neste sentido, no Brasil, a formação continuada ainda é falha. Um exemplo disso é a pouca quantidade de professores pesquisando sua própria prática, bem como o distanciamento entre universidade e escolas. É unânime na fala dos professores dos artigos citados anteriormente e que participaram da pesquisa-ação que, quando os alunos estão envolvidos em projetos desse tipo, há um melhor aprendizado e é significativo para os mesmos.

Dessa forma, é relevante o uso da pesquisa-ação, não só para a melhoria e reflexão da prática profissional, como para a melhora das aulas apresentadas aos estudantes, principalmente para aqueles de escolas públicas. 


\section{CAPÍTULO 2}

\section{Objetivos e Metodologia}

Neste capítulo serão discutidos os objetivos, a metodologia e a questão de pesquisa utilizada durante a pesquisa. Também serão apresentados os dados referentes ao estudo piloto, assim como os resultados obtidos e quais foram os desdobramentos e redefinições que ocorreram a partir dele.

\section{1 Objetivos}

A presente pesquisa teve por objetivo geral avaliar a contribuição do uso da estratégia investigativa aliada à pesquisa-ação para promover a formação do espírito científico em alunos do Ensino Médio do período noturno.

Os objetivos e metas específicas foram:

- Aplicar práticas experimentais investigativas de níveis de 1 a 4;

- Analisar a utilização do conceito científico no nível 4;

- Elaborar instrumentos de coleta de dados para a formação do espírito científico;

- Analisar a presença de indícios de espírito científico durante as aulas investigativas de nível 5;

- Triangular as entrevistas e as atividades para verificar indícios de formação do espírito científico;

- Avaliar os benefícios do uso da pesquisa-ação na prática docente.

A partir dos objetivos supracitados e diante da problemática do ensino de Química na escola pública, e a pertinência do uso da estratégia investigativa em aulas de Química aliado ao referencial teórico de Gaston Bachelard, a questão de pesquisa deste trabalho é:

Qual a contribuição do uso da abordagem investigativa no ensino noturno aliado à pesquisa-ação para a formação do espírito científico?

\subsection{Metodologia}

Esta é uma pesquisa do tipo qualitativa que, segundo Bogdan e Biklen (1994), a fonte direta de dados é o ambiente natural, sendo o investigador o instrumento 
principal. Dessa forma, a pesquisa qualitativa é rica em descrição como, por exemplo, locais e conversas onde os dados são recolhidos na forma de imagens, palavras e não, especificamente, de números.

Concomitantemente, será realizada uma pesquisa-ação que, de acordo com Ludke e André (1986), a pesquisa-ação combina simultaneamente à análise documental, à entrevista, à participação, à observação direta e à introspecção. Como neste trabalho a professora da turma foi a pesquisadora, houve grande envolvimento com os alunos em estudo com a finalidade de atingir os objetivos na situação que foi estudada.

Dessa forma, a professora como agente da mudança realizou uma pesquisaação na qual, segundo Barbier (2007), espera-se uma conversão epistemológica, uma mudança de atitude da postura acadêmica transformando a atitude filosófica do pesquisar e da sua relação com o mundo.

A pesquisa-ação educacional, segundo Barbier (2007), é, principalmente, uma estratégia para o desenvolvimento de professores e pesquisadores de modo que eles possam utilizar suas pesquisas para aprimorar seu ensino e, em decorrência, o aprendizado de seus alunos. Esse aprimoramento, de acordo com Tripp (2005), ocorre para a solução de problemas que segue os seguintes passos: identificação do problema, planejamento de uma solução, sua implementação, seu monitoramento e a avaliação de sua eficácia, buscando, também, efetuar transformações na prática docente.

Neste trabalho foi utilizada a pesquisa-ação prática: o pesquisador tem como foco contribuir para o desenvolvimento dos estudantes, o que significa que foram feitas mudanças nas aulas para melhorar a aprendizagem e a autoestima de seus alunos.

Neste contexto, diante de tantos problemas que a educação pública enfrenta, a professora, com intuito de contribuir para melhora de sua prática e propor a aplicação de novas estratégias para o ensino de Química, realizou sua pesquisa na forma de pesquisa-ação utilizando seus alunos e suas aulas como objeto de pesquisa. Para tanto, foram realizadas atividades investigativas de vários níveis a fim de que o aluno se adaptasse a esse modo de ensino. 


\subsection{Estudo piloto}

O estudo piloto foi aplicado em uma escola particular da cidade de São Carlos, onde a pesquisadora era a professora de Química. A aplicação deste estudo ocorreu no ano de 2017, entre os meses de agosto a novembro, em uma sala do primeiro ano do ensino médio, no período da manhã, com total de 32 alunos. A escola em questão foi escolhida para a aplicação do estudo piloto devido às condições estruturais e por possuir uma feira de ciências que é apresentada anualmente. Dessa forma, a apresentação do material produzido pelos alunos neste trabalho seria realizada durante a feira como uma forma de incentivá-los a participar do estudo piloto.

Atividades aplicadas durante o estudo piloto foram:

- Atividade 1: Palestra sobre corrosão desenvolvida por alunos de doutorado do Laboratório de Investigações em Ensino de Ciências Naturais (LINECIN);

- Atividade 2: Aplicação de uma folha com quatro figuras (Anexo A), as quais apresentavam queima de fogos de artifício, estados de agregação da molécula de água, corrosão de um navio e queima de um palito de fósforo. Nesta atividade, os alunos deveriam observar e explicar que tipo de fenômeno está acontecendo na figura;

- Atividade 3: Aplicação de um questionário em escala Likert para levantar o interesse pela abstração, de acordo com Bachelard (1996);

- Atividade 5: Aplicação de experimentos sobre como reconhecer as reações químicas. Os experimentos e questionamentos sobre os experimentos foram extraídos do livro: Química de Mortimer e Machado (2017);

- Atividade 6: Proposição de montagem de uma maquete sobre o tema reações químicas feita pelos próprios alunos.

\subsection{Resultados do estudo piloto}

Todas as atividades foram realizadas dentro do período de aula da professora/pesquisadora, em dias de aula dupla, visto que a escola dispunha de três 
aulas de química semanais. As atividades desenvolvidas foram elaboradas de acordo com o plano de aula da professora, portanto, os alunos tiveram uma participação efetiva em todas as atividades propostas durante o estudo piloto.

Os alunos se adaptaram muito bem às atividades investigativas, propondo roteiros e conclusões coerentes. A proposta da atividade de nível 5, juntamente com a elaboração da maquete interativa e com o tema reações químicas, se mostrou muito abrangente pela diversidade de reações que poderiam ser executadas.

Dessa forma, foi observado que os alunos tiveram dificuldade para compreender o conceito de maquete, trazendo experimentos relacionados ao tema reações químicas, porém, sem a interatividade proposta pela professora.

Devido às demandas escolares de final de ano, a não realização das maquetes esperadas e a falta de muitos alunos, não foi possível a aplicação do questionário ao final da coleta de dados.

A partir da reflexão dos dados obtidos pelo estudo piloto, foi observado que ainda faltavam instrumentos que pudessem mostrar a evolução dos alunos ao longo das atividades propostas. Sendo assim, foram realizadas algumas modificações para que pudessem dar maior suporte no auxílio da observação e da análise de mudança no sujeito de pesquisa ou formação do espírito científico. As modificações estão elencadas abaixo:

- Preparação prévia dos estudantes utilizando-se experimentos investigativos desde o nível 1 ao nível 4;

- Para as atividades de nível 5, definição prévia do tema para os alunos pesquisarem o que gostariam de saber sobre ele ao invés de propor a elaboração de uma maquete. O tema escolhido foi reações químicas;

- Aplicação do questionário inicial e final;

- Elaboração de uma redação sobre o desenvolvimento do projeto, o que o aluno aprendeu e quais as dificuldades encontradas;

- Elaboração de um "documento" onde o aluno registraria a hipótese, qual a metodologia utilizada para validar sua hipótese e quais conclusões o grupo obteve ao longo das 4 semanas de atividades;

- Entrevista com os alunos que apresentaram maior e menor participação.

\subsection{Caracterização dos sujeitos de pesquisa}

Os alunos participantes deste trabalho estudavam em uma escola pública, da cidade de Descalvado, no período noturno. A escola é situada no centro da cidade e possuía dois laboratórios e quinze salas de aula. Antigamente, havia dois 
laboratórios: um de Química e Biologia e outro de Ciências, onde ficavam as amostras de animais conservados em formol. Os laboratórios estavam desativados e foram utilizados como sala de aula por muitos anos. Com o fechamento de salas, devido à demanda de alunos ter diminuído, houve um número expressivo de salas em desuso. As turmas possuíam apenas duas aulas de Química semanais com duração de 45 minutos cada.

Os sujeitos de pesquisa tinham idade entre 15 e 17 anos e eram alunos do primeiro e segundo anos do Ensino Médio. A turma do primeiro ano possuía 15 alunos ativos no sistema Gestão Dinâmica de Administração Escolar (GDAE) ${ }^{1}$ e, no segundo ano, apresentavam-se 22 alunos ativos no sistema. Participaram deste trabalho seis alunos do primeiro ano e 14 alunos do segundo, formando um total de 20 alunos. Deste total de participantes, apenas cinco alunos trabalham de forma assalariada e dois alunos moram na zona rural, sendo o restante moradores da área urbana. A diferença de alunos participantes durante as atividades com alunos ativos no sistema se dá devido à presença flutuante dos mesmos.

\subsection{Instrumentos de coleta de dados}

A partir das observações do estudo piloto foi possível organizar a pesquisa em duas partes. A primeira parte seria a familiarização dos alunos com a abordagem investigativa e o manuseio de reagentes e vidrarias, o qual ocorreu no primeiro semestre de 2018. A segunda parte ocorreu durante o segundo semestre de 2018, onde foram realizadas as atividades investigativas nível 5 .

O primeiro instrumento utilizado foi o questionário inicial elaborado de acordo com Silva (2017) (ANEXO A) sobre percepção do nível microscópico e evidências das transformações químicas. Neste instrumento, foram apresentadas quatro figuras e era esperado que os alunos conseguissem relacionar as figuras com alguma evidência das transformações químicas, além de identificar o que ocorre microscopicamente.

Os alunos estudaram o conceito de evidências das reações químicas durante a semana de 5 a 7 de março. Na semana seguinte, ocorreu a aplicação do primeiro questionário na aula de Química (ANEXO A), em 12 de março de 2018, que constavam quatro figuras: Imagem 1: fogos de artifício; Imagem 2: mudança de

\footnotetext{
${ }^{1} \mathrm{O}$ (GDAE) é um software utilizado pela escola, no qual pode ser encontrada a vida escolar do aluno.
} 
estado físico da água; Imagem 3: corrosão de um barco; e Imagem 4: queima de um palito de fósforo. Neste instrumento, os alunos foram avaliados quanto ao tipo de hipótese ("coerente", "pouco coerente" ou "incoerente").

Os experimentos aplicados com nível 1 de abertura (ANEXO B) foram retirados do livro Química de Mortimer e Machado (2017) e o tema dos experimentos foi evidências das reações químicas.

Foram aplicadas atividades investigativas com níveis de 1 a 4 , as quais versavam sobre partícula na caixa, densidade dos materiais, chuva ácida e conservação da massa (APÊNDICE A, B, C e ANEXO C). Para elaboração das atividades investigativas foi utilizado o material de Kasseboehmer, Hartwig e Ferreira (2015). Devido ao pouco tempo disponível para as aulas, o nível 3 não foi realizado. As respostas obtidas nestas atividades foram avaliadas quanto ao tipo de resposta, sendo categorizadas em três tipos: coerente, pouco coerente ou incoerente.

Durante o estudo piloto, observou-se a necessidade de mais instrumentos que pudessem mostrar um indício de evolução do espírito científico dos alunos. Para tanto, foram criados dois instrumentos: o primeiro é o cronograma experimental e segundo uma redação ou relato do que eles aprenderam durante essas atividades. Como esses instrumentos foram utilizados estão descritos a seguir:

O Cronograma Experimental (APÊNDICE D) foi utilizado apenas nas atividades de nível 5. Semanalmente, os alunos deveriam preencher, inicialmente, com a questão de pesquisa, elaborar a hipótese e o procedimento experimental utilizado com as conclusões do experimento realizado. Na quinzena seguinte, eles deveriam trazer novamente a folha e descrever quais modificações iriam realizar e, desta forma, realizar o experimento. Este processo foi repetido a cada 15 dias, entre os meses de setembro e outubro de 2018.

O outro instrumento desenvolvido foi o relato dos estudantes, no qual eles deveriam realizar uma Redação (APÊNDICE E), escrevendo o que aprendeu, se ficou pensando nas atividades, quais as dificuldades encontradas durante a realização dos experimentos e, ao final, o aluno deveria deixar a sua opinião, se gostou do tipo de atividade e se gostaria de mais atividades desse tipo. A finalidade deste instrumento era correlacionar os dados obtidos nesta atividade com a entrevista para que fossem analisados se houve alguma evolução na escrita que mostrasse algum indício de formação de espírito científico. 
A entrevista realizada (APÊNDICE F) foi do tipo semiestruturada e os alunos foram selecionados de acordo com a participação, sendo quatro alunos de cada sala. Os alunos selecionados foram aqueles que tiveram maior e menor participação durante as atividades de nível 1 ao nível 5. A entrevista possuía dez questões para os alunos que participaram de todas as atividades de nível 5. Os alunos que não participaram de todas as atividades também foram entrevistados, porém foram realizadas apenas cinco questões, as quais o aluno era livre para respondê-las.

O diário de campo foi utilizado durante toda a coleta de dados a fim de que fossem anotadas percepções, falas dos alunos, as quais não foram possíveis identificar ao longo dos questionários aplicados. De acordo com De Araújo (2013), o diário de campo é utilizado como caderno de notas em que o pesquisador registra as conversas informais, observações do comportamento durante as falas, manifestações dos interlocutores quanto aos vários pontos investigados e, ainda, suas impressões pessoais, que podem modificar-se com o decorrer do tempo.

\subsubsection{Desenvolvimento da pesquisa}

A coleta de dados ocorreu durante os meses de março a novembro de 2018, com aplicação de uma atividade investigativa por mês durante o primeiro semestre, sendo aplicadas cinco atividades de diferentes níveis com a finalidade de os alunos se habituarem e compreenderem a abordagem investigativa. Os conceitos eram previamente explicados, sempre incentivando a participação ativa dos alunos por meio de questionamentos sobre o conteúdo que estava sendo explicado. Ao término de cada conteúdo, era aplicada uma atividade investigativa em que os alunos deveriam propor hipóteses, elaborar a metodologia e realizar as conclusões obtidas por meio do experimento. As atividades foram realizadas em aulas de 90 minutos (45 minutos cada aula, no período noturno) e os experimentos foram realizados na sala de aula. A seguir, no Quadro 2, são apresentadas as atividades realizadas ao longo do primeiro semestre. 
Quadro 2 - Cronograma de atividades aplicadas durante o primeiro semestre de 2018

\begin{tabular}{|c|c|}
\hline $\begin{array}{c}\text { Atividade (nível) / } \\
\text { Datas de aplicação }\end{array}$ & Atividade desenvolvida \\
\hline $\begin{array}{c}\text { Atividade inicial } \\
12 / 03\end{array}$ & $\begin{array}{c}\text { Questionário sobre identificação das evidências de } \\
\text { reação/ fenômeno submicroscópico. }\end{array}$ \\
\hline $\begin{array}{c}\text { Atividade nível 1 } \\
26 / 03\end{array}$ & $\begin{array}{c}\text { Experimento: Identificação das evidências de } \\
\text { reação. }\end{array}$ \\
\hline $\begin{array}{c}\text { Atividade nível } 2 \\
16 / 04\end{array}$ & Atividade Partícula na caixa \\
\hline $\begin{array}{c}\text { Atividade nível 2 } \\
30 / 04\end{array}$ & Atividade Densidade \\
\hline $\begin{array}{c}\text { Atividade nível 4 } \\
14 / 05\end{array}$ & Atividade Chuva ácida \\
\hline Atividade nível 4 \\
$18 / 06$
\end{tabular}

Fonte: Autoria Própria

A aplicação das atividades foi realizada da seguinte maneira: inicialmente, foram divididos em grupos de quatro alunos e a situação problema foi apresentada. Os alunos levaram dez minutos para discutir o problema entre seu grupo e propor hipóteses, bem como um procedimento experimental para resolver o problema. Ao final do tempo, os grupos apresentaram suas propostas com o objetivo de definir quais métodos seriam os mais coerentes a serem utilizados para resolver o problema e, portanto, deveriam ser executados. Essa ação durou cerca de 20 minutos e forneceu uma oportunidade para os grupos e seus membros discutirem suas hipóteses e suas metodologias propostas.

Depois disso, os alunos foram até a mesa da professora e escolheram os materiais que utilizariam. Mais materiais do que o necessário estava disponível, porém, os estudantes não foram informados sobre isso. Esta aplicação sistemática classifica esta atividade de investigação no nível 4 (Quadro 1). Os alunos tiveram cerca de 15 minutos para realizar o experimento e tirar conclusões. Após o experimento, cada grupo discutiu os resultados obtidos. O tempo gasto por todos os grupos para discutirem seus resultados foi de cerca de 15 minutos. Ao final de cada atividade experimental, os alunos lavavam e armazenavam os utensílios usados e 
levavam cerca de 10 minutos para arrumar suas mesas (levando em conta o início e o fim da atividade).

No segundo semestre foi realizada a segunda parte deste trabalho. A partir do mês de agosto, os alunos tiveram quinze dias para pesquisar e escolher um problema que gostariam de estudar. Após a pesquisa, os alunos trouxeram esses problemas para que a professora pudesse estudar a viabilidade do estudo e o levantamento de material necessário, visto que na escola não havia laboratório. Nos meses de setembro e outubro, quinzenalmente, os estudantes desenvolveram suas pesquisas, realizando uma modificação para o experimento escolhido a fim de conseguirem explicar suas hipóteses iniciais. As sequências de atividades executadas e as datas em que elas ocorreram encontram-se sumarizados no Quadro 3 a seguir:

Quadro 3: Cronograma de atividades aplicadas durante o segundo semestre de 2018

\begin{tabular}{|c|c|}
\hline Data & Atividade \\
\hline $29 / 08$ & Entrega do Problema \\
\hline $\begin{array}{c}\text { Realização } \\
05 / 09\end{array}$ & $\begin{array}{c}\text { Experimento Investigativo nível 5 } \\
\text { Tentativa 1 }\end{array}$ \\
\hline $\begin{array}{c}\text { Realização } \\
19 / 09\end{array}$ & $\begin{array}{c}\text { Experimento Investigativo nível 5 } \\
\text { Tentativa 2 }\end{array}$ \\
\hline $\begin{array}{c}\text { Realização } \\
03 / 10\end{array}$ & $\begin{array}{c}\text { Experimento Investigativo nível 5 } \\
\text { Tentativa 3 }\end{array}$ \\
\hline $\begin{array}{c}\text { Realização } \\
17 / 10\end{array}$ & $\begin{array}{c}\text { Experimento Investigativo nível 5 } \\
\text { Tentativa 4 }\end{array}$ \\
\hline $\begin{array}{c}\text { Realização } \\
05 / 11\end{array}$ & Redação \\
\hline $\begin{array}{c}\text { Realização } \\
07 / 11\end{array}$ & Entrevista \\
\hline
\end{tabular}

Fonte: Autoria Própria

\subsubsection{Atividades investigativas nível 5}

Inicialmente foi discutido com os alunos os passos do raciocínio científico para resolução de um problema: levantamento de hipóteses, elaboração de procedimento experimental para o teste de hipótese, coleta de dados e conclusão. Ao final da aula do dia 01/08/2018, sobre raciocínio científico, foi solicitado aos estudantes de ambas as salas que pensassem, dentro do tópico reações químicas, 
o que gostariam de investigar nesses dois meses e que trouxessem, na aula da semana seguinte, suas questões de pesquisa.

$\mathrm{Na}$ semana seguinte, na sala do segundo ano do Ensino Médio, no dia 07/08/2018, foi solicitado os problemas que eles iriam estudar durante os dois meses e sobre o que haviam pensado naquela semana. Porém, apenas um grupo trouxe, o restante ficou de pensar mais um pouco porque tiveram dificuldade, alegando estar pensando ou procurando por algo na internet.

No dia seguinte, dia 08/08/2018, os alunos do primeiro ano não trouxeram o problema ou o questionamento que queriam investigar. Dessa forma, como os alunos sentiram muita dificuldade em pensar em um problema, a professora levou os alunos até a sala de informática e os deixou livres para pesquisarem sobre o assunto que lhes interessassem, desde que envolvessem o assunto Química. Como os alunos eram em menor número, eles concordaram entre si em realizar um projeto apenas. Para tanto, eles assistiram um vídeo em que utilizavam um refrigerante de cola no leite e este último ficava incolor. Intrigados, os alunos queriam saber o porquê isso aconteceu, portanto, este grupo foi chamado de Grupo 1.

Na semana seguinte, no dia $15 / 08$, os alunos do segundo ano conseguiram se organizar em quatro grupos, com experimentos totalmente diferentes. Os grupos, apesar de realizarem reproduções de experimentos já apresentados em canais na internet, tinham alguma curiosidade ou tinham a intenção de tentar explicar o porquê daquela reação acontecer. Para que os alunos não perdessem a curiosidade, a professora aceitou a reprodução desde que pensassem e tentassem explicar o experimento quimicamente. Portanto, ao todo, foram formados cinco grupos, porém, apenas três realizaram os testes até o final (Grupo 1, Grupo 2 e Grupo 4) e apresentaram as seguintes questões de pesquisa:

- Grupo 1: Refrigerante de cola misturado com leite: qual reação química acontece?;

- Grupo 2: O que tem no limão que conduz eletricidade?;

- Grupo 3: É possível pegar fogo sem queimar?;

- Grupo 4: A acetona dissolve outros objetos?;

- Grupo 5: Por que o experimento espuma na hora da reação química?

Após definirem suas questões de pesquisas na semana seguinte, dia 22/08, os alunos receberam o Cronograma Experimental. Os alunos deveriam propor um 
experimento e elencar os reagentes para a próxima aula e entregar para a professora providenciar os reagentes necessários. Eles deveriam preencher a folha a cada encontro, sendo um total de quatro experimentos/testes a serem realizados. Portanto, adotou-se a seguinte dinâmica: uma semana eles levavam o roteiro e, na outra semana, a professora levava os materiais solicitados pelos alunos, sempre observando a periculosidade do experimento, visto que o laboratório da escola não encontrava-se a disposição no momento, pois, estava desativado. Quando necessário o uso de reagentes perigosos a professora preparava, previamente, os reagentes no laboratório de pesquisa LINECIN-USP, diluindo os reagentes e fornecendo equipamentos de proteção (luvas, óculos e jalecos). Quando possível, os reagentes químicos eram substituídos por materiais comuns do dia a dia para evitar o problema de descarte.

Este procedimento foi realizado nas duas turmas. Na aula seguinte, dia 29/08, os alunos entregaram o roteiro. Na semana posterior, no dia 05/09, a professora levou os reagentes necessários para ambas as turmas e foi realizado o primeiro teste investigativo de nível 5.

Após os quatro encontros de testes dos experimentos propostos pelos alunos, foram realizadas entrevistas semiestruturadas com quatro alunos de cada sala e as observações do professor foram feitas em um diário de campo.

\subsubsection{Análise de dados}

Os dados obtidos foram as respostas dos alunos nas atividades investigativas de nível 4, no Cronograma Experimental e na redação. Esses dados foram analisados utilizando o referencial teórico de Gaston Bachelard (1996), com a finalidade de observar em que estado o espírito científico desses alunos se encontram. Para tanto, foi observado se a escrita dos alunos evoluiu em nível de complexidade, com utilização de conceitos científicos, referências ao nível submicroscópico ou se apenas se prendem ao nível macroscópico, o que indicaria que o aluno ainda se encontra no estado concreto.

Durante a análise das respostas, foi considerado "coerente" o que o aluno sabe ou aprendeu e se está de acordo com a teoria; "pouco coerente" se o aluno identifica o fenômeno, mas não explica o que ocorre e "incoerente" quando o aluno tenta explicar, mas não utiliza a teoria adequada fugindo do assunto. Também não 
foram consideradas diferenças de anos, visto que a maioria dos alunos do segundo foi reclassificada ${ }^{2}$ do primeiro ano. Portanto, é possível assumir que a maioria dos participantes possui o mesmo nível de conhecimento.

\footnotetext{
${ }^{2}$ O sistema de reclassificação ocorre, através de uma avaliação requerida pelo aluno que está com idade superior a idade adequada para a ano que frequenta. Ao realizar a prova, se o aluno atingir uma nota igual ou maior do que cinco, ele é automaticamente promovido para o ano escolar seguinte.
} 


\section{CAPÍTULO 3}

Neste Capítulo serão discutidas todas as atividades aplicadas de nível 1 a nível 4 e serão analisados como os estudantes utilizaram os conceitos científicos.

\section{RESULTADOS E DISCUSSÕES}

No início da aplicação da coleta de dados não houve a apresentação da palestra, como ocorreu no estudo piloto devido à necessidade de deslocamento dos alunos da cidade de Descalvado para São Carlos. Um fator que impediu o transporte desses alunos para a USP foi 0 fato de a maioria trabalhar durante o dia, consequentemente, a saída deles não poderia ser realizada pela escola fora do turno em que estudavam. Diante desse cenário, a coleta de dados foi iniciada com a apresentação do vídeo do mundo de Beakman ${ }^{3}$ que explica como cientistas resolvem um problema.

\subsection{Atividade 1: Evidência das reações químicas}

Nesta atividade, os alunos deveriam descrever o que sabiam sobre cada fenômeno apresentado nas figuras (ANEXO A). Como os alunos não haviam visto o tópico sobre modelos atômicos para uma discussão microscópica, esperava-se que eles indicassem nas respostas que ocorria uma reação química quando pertinente, ou transformação física no caso da água, e que explicassem a evidência observada. $\mathrm{Na}$ Tabela1, na página a seguir, encontram-se os dados referentes às respostas apresentadas pelos alunos.

\footnotetext{
${ }^{3}$ Vídeo o Mundo de Beackman: Método científico. Disponível em:https://www.youtube.com/watch?v=L3MqQHuKGUo, acesso em 24/06/2020.
} 
Tabela 1 - Frequência das respostas dos alunos referentes as transformações físicas e químicas

\begin{tabular}{|c|c|c|c|c|}
\hline Classificação & Coerente & $\begin{array}{c}\text { Pouco } \\
\text { coerente }\end{array}$ & Incoerente & Em branco \\
\hline $\begin{array}{c}\text { Fogos de } \\
\text { artifício }\end{array}$ & 3 & 6 & 9 & 2 \\
\hline $\begin{array}{c}\text { Estados físicos } \\
\text { da água }\end{array}$ & 2 & 4 & 6 & 8 \\
\hline $\begin{array}{c}\text { Barco } \\
\text { enferrujado }\end{array}$ & 2 & 7 & 7 & 4 \\
\hline $\begin{array}{c}\text { Fósforo } \\
\text { queimando }\end{array}$ & 0 & 6 & 8 & 6 \\
\hline
\end{tabular}

Fonte: Autoria Própria

De acordo com a Tabela 1, observa-se que a representação dos fogos de artifício apresentou maior número de respostas coerentes. Os alunos, de certa forma, conseguiram associar a cor com a evidência de reação, porém, quando comparados com a imagem do palito de fósforo queimado, os alunos não conseguiram identificar a queima ou a presença de luz como uma evidência de reação química.

Para as respostas pouco coerentes, observa-se que apenas sete alunos apresentaram respostas deste tipo para a imagem do navio enferrujado. Neste desenho, os alunos se arriscaram a escrever mais, porém, os alunos ainda associam a ocorrência de ferrugem à reação do ferro com água e se utilizam de animismos, tais como "... barco em decomposição..." ou seja, utilizam características de seres vivos para a substâncias, sendo este tipo de resposta característico de um espírito que se encontra no estado concreto. Um exemplo de resposta encontra-se abaixo:

"Esta figura de um barco em decomposições na beira do mar se encontra cheio de ferrugem". (Aluno 9)

De acordo com Bachelard (1996), o aluno, ao utilizar animismos, indica que ele está ligado à experiência primeira, pois é possível observar, durante as respostas descritas, convicções e ou achismos prévios que o sujeito não consegue 
se desvencilhar. Mortimer (1995) explica que, muitas vezes, os alunos não reconhecem as transformações e tendem a explicar o fenômeno da forma que ele percebe e não se referindo às mudanças microscópicas e atômicas.

Ainda nas respostas pouco coerentes, a imagem representada pela molécula de água apresenta quatro respostas com esta classificação, o que é significativo, pois os estudantes conseguiram identificar na figura a molécula de água. Eles não indicaram qual tipo de agregação das moléculas era pertencente a determinado estado físico, o que significa que os alunos ainda não conseguem compreender o nível submicroscópico das moléculas. No decorrer da atividade, muitos alunos perguntaram se o desenho representado era a molécula de DNA.

Em relação a representação dos estados físicos da água, foi possível perceber que os alunos não conseguiram identificar a representação submicroscópica referente aos estados físicos sólido, líquido e gasoso. Segundo Johnstone (1991), o professor, durante o ato de ensinar Química, deve percorrer o triângulo (Figura 1) macroscópico, sub microscópico e simbólico. A não consideração de um desses vértices impede que o estudante compreenda ideias subsequentes. Dessa forma, observa-se que, possivelmente, o aluno tenha compreendido que a fórmula da água é $\mathrm{H}_{2} \mathrm{O}$, sabe que água é encontrada nos três estados físicos, mas não compreendeu que a água é composta por um átomo de oxigênio e dois de hidrogênio, além de não compreender microscopicamente que, durante os estados físicos da água, há diferentes formas de agregação das moléculas, por isso a mudança de estado físico.

Figura 1 - Níveis de representação do conhecimento químico

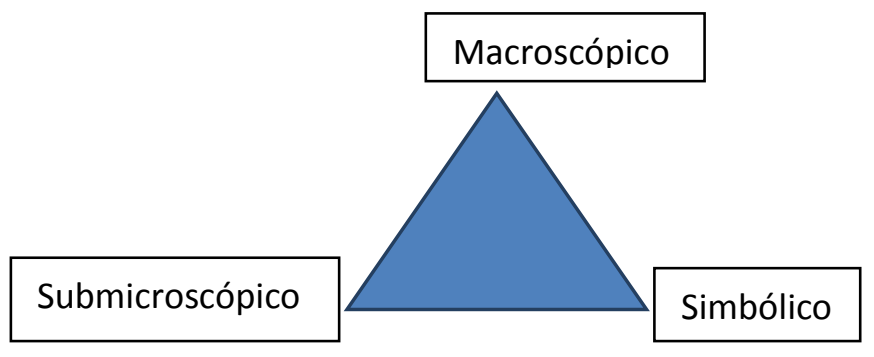

Fonte: Adaptado de JOHNSTONE, 1991, p. 78.

As imagens que obtiveram maior número de respostas incoerentes foram as figuras dos fogos de artifício e do palito de fósforo queimando. As respostas que 
foram consideradas incoerentes foram aquelas em que não houve a tentativa de explicação para o fenômeno, ou seja, o aluno não relatou que houve queima, uma transformação química ou fugiu do contexto. Quanto ao fogo no palito, foram consideradas incoerentes as respostas que não apresentavam a justificativa da queima devido ao oxigênio presente no ar, identificação de uma reação química, evidência da reação de liberação de luz e calor, ou fugiram do contexto.

Nas atividades analisadas, observou-se que os alunos escreveram, na folha de respostas, o que eles realmente observaram na imagem, como pode ser observada na resposta do Aluno 10. Dessa forma, foi possível observar que a maioria dos alunos não conseguiu relacionar dois conceitos para a explicação dos fenômenos, tais como: identificação de uma reação química por meio da evidência da liberação de luz e a queima de substâncias que, para tal, é necessária a presença de oxigênio, como pode ser observado na resposta do Aluno 14, que identifica uma reação química, mas, não explica o porquê.

Apesar de poucos alunos relatarem a queima dos fogos ou do palito de fósforo, em nenhuma das respostas foi observada a associação da presença do oxigênio para que a reação aconteça. Ressalta-se que os alunos ainda não haviam aprendido os conceitos sobre modelos atômicos, portanto, não conseguiram explicar a presença de cor nos fogos de artifício, como pode ser observado a seguir:

"É ano novo é químico pelos fogos. Fogos subindo e pessoas aparentemente felizes pelo ano novo que está vindo cores muito lindas (sic)."(Aluno 10)

"Esse é um fator químico e material usa o material da natureza e o químico e os dois fatores diferentes (sic)." (Aluno 14)

Em dois casos, observaram-se atividades totalmente em branco. Quando o aluno foi questionado pela professora, ele apenas respondeu "não sei" e não se dispunha a escrever nada. Em outras atividades, esse comportamento foi algo muito pontual, alguns justificaram que era por não saberem explicar o fenômeno devido ao excesso de faltas, portanto, acabam perdendo a continuidade da matéria. Quando questionados sobre o porquê de deixar em branco, muitos justificaram que tinham 
medo de escrever algo errado. O medo de errar pode ser notado nas respostas referentes à figura que representa a molécula de água, pois ocorreu o maior número de atividades em branco devido ao fato de exigir uma explicação mais elaborada, mostrando que foi trabalhado muito pouco o nível submicroscópico em aula. Por isso, os alunos não associaram a representação da água e sua representação submicroscópica referentes às mudanças de estados físicos da água.

\subsection{Atividade nível 1: identificação das evidências de reação}

No dia 26 de março foi realizada uma sequência de experimentos nível 1 no qual o aluno recebe o roteiro, executa o experimento e a professora auxilia a tirar suas conclusões. Esta atividade teve o intuito de familiarizar os alunos com a experimentação, visto que muitos deles não participaram de atividades experimentais durante o ensino fundamental. Ao todo, foram realizados cinco experimentos sobre evidências das reações químicas. Durante o experimento, os alunos deveriam responder as seguintes questões:

1. Descrevam as características macroscópicas do sistema inicial;

2. Descrevam as características macroscópicas do sistema quando vocês adicionaram os reagentes;

3. Qual é a evidência de que ocorreu uma transformação?;

4. Como vocês poderiam identificar as novas substâncias que foram formadas?;

5. Se vocês determinassem a massa $\left(m_{i}\right)$ do sistema inicial e a massa $\left(m_{\mathrm{f}}\right)$ do sistema final depois que a transformação se completou, vocês acham que mi seria maior, menor ou igual a $\mathrm{m}_{\mathrm{f}}$ ? Justifiquem;

6. Se a reação tivesse se passado em um sistema fechado, um tubo de ensaio fechado com uma rolha, por exemplo, a resposta ao item 5 seria a mesma? Justifiquem.

Inicialmente, os alunos não realizaram a leitura do roteiro, não conseguiram compreender o que ele solicitava e questionaram o que era para ser feito ao invés de realizarem a leitura. Uma cópia do roteiro utilizado encontra-se no ANEXO B. Como era a primeira atividade experimental realizada pelos alunos, foi feita uma leitura conjunta e o procedimento foi explicado. Um exemplo de como a atividade foi aplicada encontra-se na Figura 2 a seguir: 
Figura 2 - Primeira atividade experimental dos alunos realizada em sala de aula

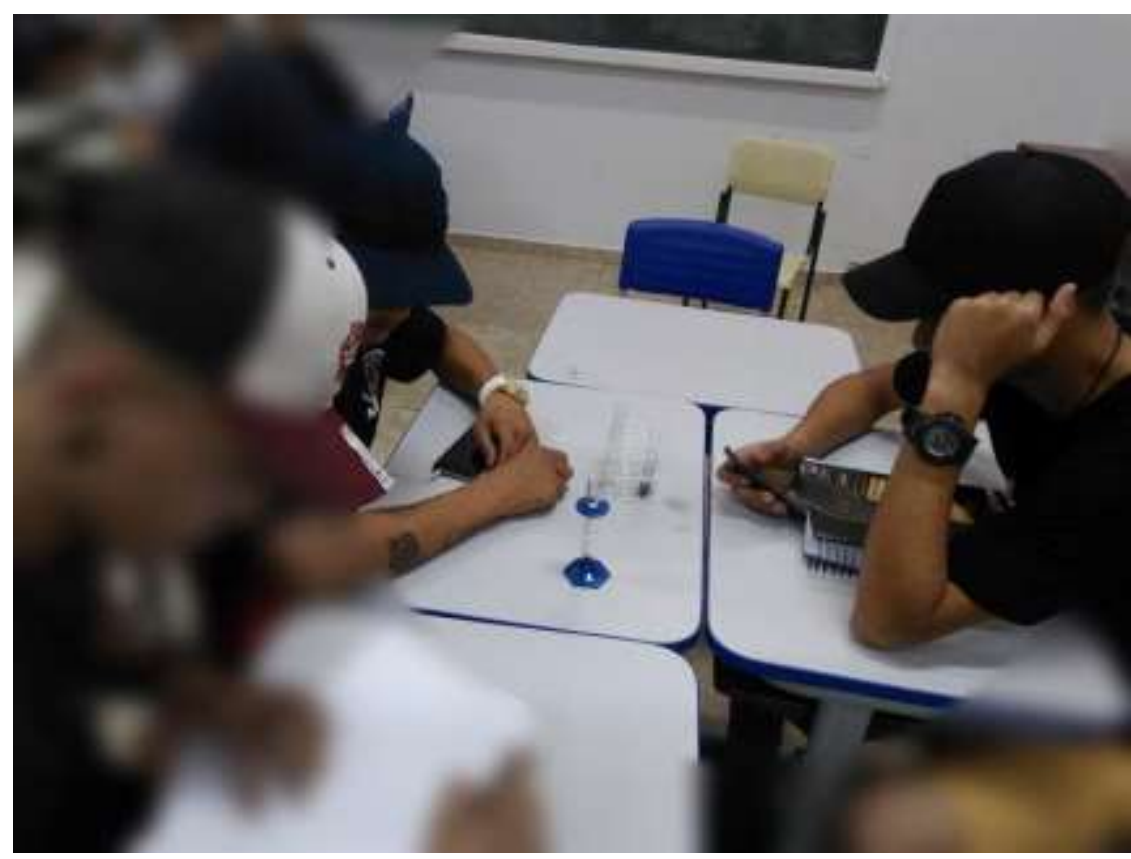

Fonte: Autoria Própria

Durante a resolução das perguntas que estão no roteiro, percebe-se que os alunos apresentavam muita dificuldade em elaborar uma resposta quimicamente adequada, além de medo de errar e, inicialmente, ficarem tímidos. Durante o desenvolvimento dos demais experimentos, os alunos foram se familiarizando com a leitura do procedimento e ficaram mais abertos para a tentativa de explicações dos experimentos realizados.

O primeiro experimento a ser desenvolvido foi a reação entre o ácido clorídrico e zinco, onde os dados obtidos estão sumarizados na Tabela 2 a seguir: 
Tabela 2 - Comparação de respostas dos alunos referentes à Reação entre $\mathrm{HCl}$ e $\mathrm{Zn}$ metálico utilizando sistema aberto e fechado

\begin{tabular}{|c|c|c|c|c|}
\hline $\begin{array}{c}\text { Classificação } \\
\text { de Respostas }\end{array}$ & $\begin{array}{c}\text { Frequência } \\
\text { 1 ano } \\
\text { (sistema } \\
\text { aberto) }\end{array}$ & $\begin{array}{c}\text { Frequência } \\
2 \text { ㅇ ano } \\
\text { (sistema } \\
\text { aberto) }\end{array}$ & $\begin{array}{c}\text { Frequência } \\
\text { 1 ano } \\
\text { (sistema } \\
\text { fechado) }\end{array}$ & $\begin{array}{c}\text { Frequência } \\
2^{\circ} \text { ano } \\
\text { (sistema } \\
\text { fechado) }\end{array}$ \\
\hline Coerente & 0 & 0 & 5 & 7 \\
\hline $\begin{array}{c}\text { Pouco } \\
\text { coerente }\end{array}$ & 10 & 8 & 10 & 15 \\
\hline Incoerente & 9 & 14 & 4 & 0 \\
\hline
\end{tabular}

Fonte: Autoria Própria

Observando os dados da Tabela 2, nota-se que não houve respostas coerentes quando o sistema está aberto, porém foram observadas cinco respostas do tipo "coerente" quando o sistema está fechado, isto pode ser observado no trecho escrito pelo aluno quando questionado sobre a conservação da massa:

"Se o sistema fosse fechado a massa inicial seria igual a final". (Aluno 4)

Também foi observado um maior número de respostas "pouco coerentes" quando o sistema está aberto, como ilustrado no trecho a seguir:

"Mi é menor que a massa final, por que houve liberação de gás" (sic).

(Aluno 7)

Porém, quando o sistema está fechado, é perguntado aos alunos se o resultado obtido seria igual ao sistema aberto da questão anterior. Os alunos argumentam sobre a conservação da massa, como pode ser observado a seguir:

"O efeito é o mesmo, mas o gás não some pois a caixa está fechada e não libera gás.”(sic) (Aluno 8) 
Os alunos do segundo ano tiveram uma maior quantidade de respostas incoerentes quando indagados sobre a reação no sistema aberto, como pode ser observada na resposta abaixo.

"Mi é menor que a massa final."

(Aluno 4)

Entretanto, alguns alunos compreenderam que, no sistema fechado, a massa se conservará, porém, não conseguem explicar o porquê, como observada na resposta abaixo:

"No sistema fechado: Mi=Mf." (sic) (Aluno 9)

No geral, todos os alunos conseguiram identificar que a evidência da reação era a liberação de gás. Quando os alunos foram indagados sobre a conservação da massa no sistema aberto, observa-se que não compreenderam que a massa se conserva independente do sistema aberto ou fechado. Os alunos ainda estão presos à observação primeira, o que os impede de tentar explorar explicações para o que ocorreu no experimento. Segundo Bachelard (1996), atitudes desse tipo mostram que o sujeito se encontra no estado concreto, pois, ele se contenta com respostas rápidas e não questiona o que ocorre durante a transformação química.

A maioria dos alunos conseguiu identificar que no sistema fechado a massa se conserva, o que mostra que os alunos estão presos as observações primeiras, já que, com o sistema fechado, a liberação de gás não vai para fora do tubo, então, para o aluno, a massa se conservou.

Identificou-se que os alunos escrevem muito pouco e não justificam as suas respostas. Segundo Bachelard (1996), ao se contentarem com respostas rápidas, pode-se inferir que os alunos estejam no estado concreto, dessa forma, é necessário que sejam aplicadas mais atividades que propiciem a escrita cientifica até que 0 aluno crie o hábito de pensar e escrever cientificamente. 
O segundo experimento realizado foi a reação da queima de magnésio metálico, onde todos os alunos acertaram que a evidência da reação era a presença de luz. Um resumo dos dados encontrados e das respostas apresentadas pelos alunos encontram-se sumarizadas na Tabela 3 a seguir:

Tabela 3 - Reação de magnésio metálico com $\mathrm{O}_{2}$ comparações entre sistema aberto e fechado

\begin{tabular}{|c|c|c|c|c|}
\hline $\begin{array}{c}\text { Classificação } \\
\text { das respostas }\end{array}$ & $\begin{array}{c}\text { Frequência } \\
1^{\circ} \text { ano } \\
\text { (sistema } \\
\text { aberto) }\end{array}$ & $\begin{array}{c}\text { Frequência } \\
2^{\circ} \text { ano } \\
\text { (sistema } \\
\text { aberto) }\end{array}$ & $\begin{array}{c}\text { Frequência } \\
1^{\circ} \text { ano } \\
\text { (sistema } \\
\text { fechado) }\end{array}$ & $\begin{array}{c}\text { Frequência } \\
2^{\circ} \text { ano } \\
\text { (sistema } \\
\text { fechado) }\end{array}$ \\
\hline Coerente & 0 & 0 & 8 & 6 \\
\hline $\begin{array}{c}\text { Pouco } \\
\text { coerente }\end{array}$ & 10 & 4 & 6 & 0 \\
\hline Incoerente & 9 & 6 & 5 & 6 \\
\hline $\begin{array}{c}\text { Respostas em } \\
\text { branco }\end{array}$ & 0 & 12 & - & 10 \\
\hline
\end{tabular}

Fonte: Autoria Própria

Apesar dos alunos identificarem a evidência de luz, ainda não compreenderam, microscopicamente, que a reação de queima envolve presença de oxigênio e que ele também faz parte da reação. Não houve resposta coerente para o sistema aberto, porém, para o sistema fechado, foram oito respostas coerentes para o primeiro ano e seis respostas para o segundo ano. Um exemplo de resposta coerente quando questionados sobre a conservação da massa em relação às massas iniciais e finais para o sistema fechado encontra-se a seguir:

"Não, seria a mesma resposta porque iríamos conseguir medir a massa inicial que será a mesma no final." (Aluno 10)

De acordo com a resposta dada pelo aluno, percebe-se que ele prevê que é possível medir a massa inicial e final e que elas serão iguais enquanto, no sistema aberto para o aluno em questão, não é possível saber a massa inicial do oxigênio. 
Foram elencadas dez respostas como "pouco coerentes" para os alunos de primeiro ano e quatro respostas para os alunos de segundo ano, quando o sistema é considerado aberto. Quando o sistema é considerado fechado, observa-se seis respostas "pouco coerentes" no primeiro ano e nenhuma no segundo ano.

De acordo com as respostas encontradas, percebe-se que o aluno enxerga a reação entre magnésio e oxigênio como uma fusão ou junção de átomos, apesar de ainda não ter sido apresentado aos alunos os tipos de reações químicas. Um exemplo de resposta "pouco coerente" encontrada para os sistemas aberto e fechado encontra-se respectivamente abaixo:

"Iria estar menor no início pois no final estaria com a fusão de O com Mg." (Aluno 7)

"Não seria a mesma resposta porque iria conseguir medir a massa de oxigênio pois estaria preso." (Aluno 2)

De acordo com as respostas acima, observa-se que o aluno se atentou em dizer que o oxigênio ficaria preso e daria para pesá-lo. Isso mostra que os alunos estão tentando explicar mais suas respostas e tornando-as mais completas.

Quimicamente, empregar o uso do termo fusão poderia ser considerado errôneo, já que prevê uma transformação física. No contexto da explicação do aluno 7, é possível compreender que ele está tentando explicar a junção dos átomos de Magnésio e Oxigênio, utilizando o termo fusão para explicar uma reação química, o que justifica ser uma resposta parcialmente correta. Também é possível observar que o Aluno 10 apresenta uma resposta incoerente, percebendo a fumaça como uma evidência de reação e atribuindo a ela a diminuição da massa.

As respostas incoerentes foram apresentadas por nove alunos do primeiro ano e seis alunos do segundo ano quando questionados sobre o sistema aberto. Quando o sistema é considerado fechado, o número de respostas incoerentes para o primeiro ano cai para cinco alunos e para o segundo ano aumenta para dez. As respostas para os sistemas aberto e fechado encontram-se respectivamente a seguir: 
"...quando ele entra em contato com o fogo ele diminui porque libera a fumaça, mas não todo oxigênio." (Aluno 10)

"Sim." (Aluno 7)

Nota-se que o aluno não compreende que a fumaça é gás liberado e ainda reforça: “... não todo o oxigênio", podendo-se observar que o aluno está preso ao macroscópico, ou seja, ao que se vê, dessa forma se liberou fumaça, diminui a massa e não há conservação da massa.

Outro fato que chama atenção é a quantidade de atividades com a última pergunta em branco ou com apenas a resposta com a palavra sim, sem justificativa do porquê da conservação da massa. $O$ uso da palavra sim mostra que esses alunos se satisfazem com respostas simples, sem a necessidade de questionar ou explicar. Bachelard (1996) atribui essas explicações rasas como um obstáculo para a formação do espírito científico, o qual ele nomeia de conhecimento geral, no qual o sujeito se dá por satisfeito com explicações simples, sem realizar indagações mais profundas, portanto, não consegue explicar o fenômeno.

Como na atividade anterior, os alunos ainda possuem dificuldade em perceber a conservação da massa quando o sistema está aberto, porém, quando o sistema é considerado fechado, na segunda atividade pode-se perceber um aumento de número de respostas coerentes, indicando que a massa se conserva. Pode-se sugerir que os alunos possam estar começando a compreender como verificar se há conservação da massa ou não.

A terceira reação foi realizada na semana seguinte. Devido à dificuldade de regularidade na presença dos estudantes, a atividade foi aplicada com menos alunos. A reação que foi aplicada entre sulfato de cobre e hidróxido de sódio. Todos os participantes indicaram que a evidência era a formação de precipitado e mudança de cor. Um resumo das respostas dos alunos referentes às reações realizadas nos sistemas aberto e fechado são apresentadas na Tabela 4 a seguir: 
Tabela 4 - Reação de sulfato de cobre II e hidróxido de sódio realizada nos sistemas aberto e fechado

\begin{tabular}{|c|c|c|c|c|}
\hline $\begin{array}{l}\text { Classificação } \\
\text { das respostas }\end{array}$ & $\begin{array}{c}\text { Frequência } \\
1^{\circ} \text { ano } \\
\text { (sistema } \\
\text { aberto) }\end{array}$ & $\begin{array}{c}\text { Frequência } \\
2^{\circ} \text { ano } \\
\text { (sistema } \\
\text { aberto) }\end{array}$ & $\begin{array}{c}\text { Frequência } \\
1^{\circ} \text { ano } \\
\text { (sistema } \\
\text { fechado) }\end{array}$ & $\begin{array}{c}\text { Frequência } \\
2^{\circ} \text { ano } \\
\text { (sistema } \\
\text { fechado) }\end{array}$ \\
\hline Coerente & 0 & 0 & 10 & 0 \\
\hline $\begin{array}{c}\text { Pouco } \\
\text { coerente }\end{array}$ & 4 & 0 & 0 & 4 \\
\hline Incoerente & 6 & 14 & 0 & 10 \\
\hline $\begin{array}{c}\text { Respostas em } \\
\text { branco }\end{array}$ & 4 & 2 & 4 & 2 \\
\hline
\end{tabular}

Fonte: Autoria Própria

Inicialmente, durante a realização dos experimentos no sistema aberto, não são observadas respostas coerentes. Interessante observar que os alunos atribuíram o aumento de massa ao sólido formado e não conseguiram identificar que a reação ocorreria igualmente nos sistemas aberto e fechado, portanto não estaria prevista mudança de massa. Outro dado a ser observado é que eles atribuíram a conservação de massa à ausência de liberação de gás como podemos observar na resposta abaixo:

"Massa inicial é igual a final, porque não teve liberação de gás."(Aluno11)

O uso da expressão liberação de gás mostra que os alunos estão se apropriando de palavras e termos científicos. Durante a realização do experimento, os alunos comentaram que a massa final da reação seria maior devido ao fato de ocorrer a formação de precipitado. Na literatura, é reportada esta dificuldade que os alunos possuem em compreender o precipitado como parte da reação e não algo a mais que foi colocado no experimento, como pode ser observado no exemplo incoerente logo abaixo:

"la ser maior por causa do precipitado." (Aluno 2) 
Mortimer (1995), ao comparar as dificuldades que os alunos encontram durante o desenvolvimento do tópico reações químicas, observou que, quando os alunos prevêem uma reação onde ocorre precipitação, consecutivamente produz um aumento de massa do sistema, isso ocorre devido ao fato do aluno confundir densidade com massa. Outros trabalhos que comparam reações químicas nos sistemas aberto e fechado, também encontraram alunos com as mesmas concepções, como no trabalho de Barker \&Millar (1999), Özmen e Alipaşa (2003).

Quando os alunos são indagados sobre o que aconteceria se a reação ocorresse em sistema fechado, obtêm-se respostas coerentes, ou seja, que ocorre a conservação da massa, porém, há também um alto índice de respostas incoerentes, como pode ser observado na Tabela 4. Um exemplo de resposta coerente pode ser encontrado abaixo:

"A massa seria conservada no sistema fechado." (sic) (Aluno 11)

Pode ser observado que os alunos assimilaram que o sistema fechado não há perda nem ganho de massa, ou seja, para o aluno, o precipitado não interfere no sistema fechado. Neste sentido, observa-se que alguns compreendem que, independente do meio, a reação irá ocorrer, mas não prediz o que ocorre com a massa.

“A reação irá acontecer com o tubo aberto ou fechado."(Aluno 4)

Portanto, a explicação acima foi considerada pouco coerente pois mostra que o aluno entendeu que a reação ocorre independente se o tubo estiver aberto ou fechado, mas não explica se ocorre a conservação da massa ou não. Observando a resposta considerada incoerente, logo abaixo, o aluno afirma que, no sistema fechado, a resposta não será igual ao item anterior (sistema aberto) e justifica que não será igual porque não houve queima, porém, em nenhum momento foi citado 
nesse experimento a presença de fogo. Devido a essa consideração desconexa a resposta foi considerada incoerente.

"Não por que não ove queima." (sic) (Aluno 2)

O próximo experimento entre ácido clorídrico e hidróxido de sódio causou um certo estranhamento aos alunos já que, ao colocarem para reagir o ácido e a base, visualmente nada acontece. Como os alunos sempre enxergavam uma evidência e dessa vez a reação não apresentou nenhuma das evidências estudadas, os estudantes chegaram à conclusão de que a reação não se concretizou. Quando os alunos foram indagados sobre se houve conservação da massa, foram obtidas as seguintes respostas que estão mostradas na Tabela 5:

Tabela 5 - Reação entre ácido clorídrico e hidróxido de sódio sistema aberto e fechado

\begin{tabular}{|c|c|c|c|c|}
\hline Respostas & $\begin{array}{c}\text { Frequência } \\
\text { 1ํ ano }^{\circ} \\
\text { (sistema } \\
\text { aberto) }\end{array}$ & $\begin{array}{c}\text { Frequência } \\
2^{\circ} \text { ano } \\
\text { (sistema } \\
\text { aberto) }\end{array}$ & $\begin{array}{c}\text { Frequência } \\
1^{\circ} \text { ano } \\
\text { (sistema } \\
\text { fechado) }\end{array}$ & $\begin{array}{c}\text { Frequência } \\
\text { 2ํano } \\
\text { (sistema } \\
\text { fechado) }\end{array}$ \\
\hline Coerente & 13 & 10 & 17 & 6 \\
\hline $\begin{array}{c}\text { Pouco } \\
\text { coerente }\end{array}$ & 0 & 0 & 0 & 0 \\
\hline Incoerente & 4 & 0 & 0 & 4 \\
\hline $\begin{array}{l}\text { Respostas } \\
\text { em branco }\end{array}$ & 4 & 11 & 4 & 11 \\
\hline
\end{tabular}

Fonte: Autoria Própria

Ao observar a resposta sobre conservação da massa no experimento 4, notase que os alunos ainda esperam durante a reação que ocorra uma evidência que prove que a reação ocorreu, porém, foram encontradas respostas coerentes tanto no sistema aberto, quanto no fechado. Quando o sistema é considerado fechado, os alunos identificam a conservação da massa onde encontramos 17 respostas coerentes para o primeiro ano, enquanto, para o segundo ano, apenas 6 respostas coerentes foram apresentadas, como pode ser observado no exemplo abaixo: 
“Mi=Mf, o sistema fechado não interfere."(Aluno 8)

Percebe-se que, para os alunos, ficou claro que, quando o sistema está fechado, não há perdas e a massa sempre se conserva.

Foram consideradas incoerentes as respostas que apresentam MI equivalente a massa inicial e MF igual à massa final, sem justificativa do porquê. Observa-se, também, a grande quantidade de alunos que não responderam à questão. Uma hipótese que pode ser considerada é que, como não houve evidência visível para o aluno, para eles, não ocorreu a reação química. Um detalhe a ser mencionado é que houve uma grande quantidade de respostas copiadas entre os colegas ao invés de escreverem suas próprias observações.

Apenas quatro respostas indicam que a massa não será igual sem justificar o porquê, portanto foram consideras incoerentes devido à falta de justificativa, como pode ser observado na resposta reescrita abaixo.

“A massa não será igual." (Aluno 2)

A reação é repetida, todavia, com o uso do indicador fenolftaleína. Quando a reação é novamente realizada com o uso do indicador, os alunos reconhecem que a mudança de cor de incolor para rosa é indicativo de evidência da reação entre a base com o indicador.

As questões para este tópico não questionavam sobre a conservação da massa e, sim, sobre quais evidências da decorrência de transformação. Um recorte do roteiro encontra-se abaixo:

Q25. Descrevam as características do sistema inicial (solução de $\mathrm{NaOH}$, solução de fenolftaleína e solução de $\mathrm{HCl}$ ) antes da transformação;

Q26. Descrevam as características do sistema quando vocês adicionaram gotas da solução de fenolftaleína à solução de $\mathrm{NaOH}$;

Q27. Qual a evidência de que ocorreu uma transformação?;

Q28. Como vocês poderiam identificar as novas substâncias que foram formadas?;

Q29. Descrevam as características do sistema quando vocês adicionaram a solução de $\mathrm{HCl}$ à solução de $\mathrm{NaOH}$ contendo gotas da solução de fenolftaleína.

Q30. Qual a evidência de que ocorreu uma transformação?;

Q31. Como vocês poderiam identificar as novas substâncias que foram formadas? 
Uma tabulação das respostas apresentadas pelos alunos referentes à ausência de $\mathrm{HCl}$ e a presença de $\mathrm{HCl}$ frente ao uso de $\mathrm{NaOH}$ com indicador fenolftaleína é apresentada na Tabela 6 a seguir.

Tabela 6 - Reação entre Hidróxido de sódio com fenolftaleína (Evidência da transformação)

\begin{tabular}{|c|c|c|c|c|}
\hline Respostas & $\begin{array}{c}\text { Frequência } \\
1^{\circ} \text { ano } \\
\text { Sem } \mathrm{HCl}\end{array}$ & $\begin{array}{c}\text { Frequência } \\
2^{\circ} \text { ano } \\
\text { Sem } \mathrm{HCl}\end{array}$ & $\begin{array}{c}\text { Frequência } \\
1^{\circ} \text { ano } \\
\text { Com HCl }\end{array}$ & $\begin{array}{c}\text { Frequência } \\
2^{\circ} \text { ano } \\
\text { Com HCl }\end{array}$ \\
\hline Coerente & 7 & 12 & 7 & 16 \\
\hline $\begin{array}{c}\text { Pouco } \\
\text { coerente }\end{array}$ & - & - & - & - \\
\hline Incoerente & - & - & - & - \\
\hline $\begin{array}{l}\text { Respostas } \\
\text { em branco }\end{array}$ & - & 4 & - & - \\
\hline
\end{tabular}

Fonte: Autoria Própria

A atividade tinha como objetivo mostrar aos alunos que, mesmo que eles não percebam que a reação ocorreu visualmente, há a ocorrência da reação. Esta primeira atividade, quando o aluno adiciona fenolftaleína à base e percebe a mudança de coloração, para ele há uma reação química, isto é tão verdadeiro para o aluno, que foi possível contabilizar apenas respostas "coerentes" no primeiro ano enquanto, para o segundo ano, foi possível observar apenas doze respostas "coerentes", sendo "quatro incoerentes". Foram consideradas "coerentes" as respostas que versavam sobre mudança de cor, visto que os alunos não conhecem o conceito de deslocamento de equilíbrio por parte do indicador. A resposta unânime para ambas as turmas foi "mudança de cor", tanto que pode ser observado que não houve respostas "pouco coerentes" e "incoerentes", pois está sendo considerado o que $o$ aluno sabe.

Dessa forma, é possível confirmar que, para o aluno, é importante essa mudança visual, ou seja, ele ainda está preso à experiência primeira de acordo com Bachelard (1996), isto é, preso ao estado concreto, precisando ver para acreditar que ocorreu um fenômeno. Quando o aluno adiciona ácido a esse primeiro tubo, a substância fica incolor, e novamente, acredita que houve uma reação química. 
Durante este experimento, além dos alunos observarem a ausência de cor, também sentiram o tubo de ensaio quente, como pode ser observado na resposta abaixo, que foi unânime para os dois grupos de alunos em estudo.

"Evidência: ficou quente, mudou de cor (branco)." (Aluno 9)

Ao final da realização da atividade, foi explicado o porquê da ausência de evidência durante a reação de ácido adicionado à base, que ocorreu a formação de sal e que este estaria dissolvido em água. Também foi explicado, posteriormente, aos alunos o porquê da mudança da cor rosa para incolor quando o ácido foi adicionado logo após a adição de fenolftaleína. Essa explicação foi realizada para que ficasse claro para os alunos que nem toda "evidência" ou a falta dela não quer dizer que haja uma reação ou não.

\subsection{Atividade nível 2: Partícula na caixa}

A atividade partícula na caixa foi aplicada como primeira atividade investigativa a fim de que eles compreendessem que eram sujeitos ativos nos processos de ensino e de aprendizagem. A ideia da aplicação desta atividade é sugerir que na ciência nem sempre as "caixas" são abertas e nem sempre as hipóteses são comprovadas na prática. Inicialmente, os alunos tinham em mãos uma lista de oito objetos que poderiam estar ou não na caixa recebida, sendo a única pista que havia pelo menos quatro objetos na caixa. Apenas três alunos participaram da atividade na turma do primeiro ano do Ensino Médio, portanto, as respostas foram classificadas por aluno, e se referem ao fato do porquê de terem acertado ou não os objetos na caixa. Os dados obtidos encontram-se na Tabela 7: 
Tabela 7 - Dados obtidos após atividade partícula na caixa no 1ํano do Ensino Médio

\begin{tabular}{|c|c|c|}
\hline Aluno & Acertos & Porquê \\
\hline Aluno 1 & 1 & $\begin{array}{c}\text { "Porque eu não fiz todos os testes } \\
\text { necessários pois o som estava parecido } \\
\text { e achei que estava parecido, mas estava } \\
\text { com objetos diferentes." }\end{array}$ \\
\hline Aluno 2 & 2 & $\begin{array}{c}\text { "Porque não fiz todos os testes e não foi } \\
\text { necessário porque o som estava muito } \\
\text { parecido." }\end{array}$ \\
\hline Aluno 3 & 1 & Porque o som estava muito parecido. \\
\hline
\end{tabular}

Fonte: Autoria Própria

A princípio, os alunos ficaram muito curiosos para saber o que havia dentro da caixa. Chacoalharam, tocaram os materiais até que conseguissem encontrar um barulho parecido. Foi aberta a caixa de cada aluno e comparado o que havia dentro da caixa do professor ao que havia dentro da caixa do aluno. Dois alunos acertaram apenas um objeto e um aluno acertou dois objetos. Em seguida, os alunos responderam à folha de questões. Novamente, a atividade foi realizada, os alunos estavam motivados a tentar acertar todos os objetos. Na sequência, as peças foram trocadas e redistribuídas. Ao final da atividade, foi avisado que não seriam abertas as caixas e os alunos ficaram frustrados por não poderem verificar os acertos previamente realizados durante as tentativas de suposições. Os alunos ficaram intrigados quando a professora disse que, na ciência, nem sempre o que se espera é observado, portanto, a partir disso, é necessário formular novas hipóteses, assim como eles fizeram ao tentar descobrir o que havia na caixa.

No segundo ano também foi realizada a mesma prática, porém em grupos, onde participaram da atividade 17 alunos e observou-se que a maioria identificou quais objetos estavam presentes na caixa entregue a eles. As respostas obtidas encontram-se na Tabela 8: 
Tabela 8 - Dados obtidos após atividade partícula na caixa no $2^{\circ}$ ano do ensino médio

\begin{tabular}{|c|c|c|}
\hline Alunos & Acertos & Porquê \\
\hline Grupo 1 & 4 acertos & $\begin{array}{c}\text { "Chegamos ao resultado por meio de } \\
\text { testes colocando objetos na caixa e } \\
\text { vendo se fazia o mesmo som e se tinha } \\
\text { o mesmo peso. Após várias tentativas } \\
\text { chegamos aos objetos certos." }\end{array}$ \\
\hline Grupo 2 & 1 acerto & $\begin{array}{r}\text { "Por causa dos sons, principalmente o } \\
\text { metálico." }\end{array}$ \\
\hline Grupo 3 & 4 acertos & $\begin{array}{c}\text { "Balançando a caixa e ouvindo o som } \\
\text { até descobrir o que tinha dentro." }\end{array}$ \\
\hline
\end{tabular}

Fonte: Autoria Própria

Quando a atividade foi realizada novamente, os alunos não ficaram tão ansiosos como os alunos do primeiro ano. Todavia, esta turma ficou agitada quando foram avisados de que a segunda caixa não seria aberta, mostrando que, mesmo os alunos acertando os objetos na primeira tentativa, os motivaram a tentar novamente a quererem acertar.

Em ambas as salas, foram observadas curiosidade em abrir a caixa quando 0 experimento é repetido pela segunda vez. Nos alunos de primeiro ano, observa-se que eles utilizaram o mesmo "plano" para identificar os objetos. Também se observa que, quando o experimento foi realizado novamente, os alunos tomaram mais cuidado e demoraram mais tempo para identificar o que havia na caixa, pois queriam acertar o conteúdo dela.

Nos alunos de segundo ano, considera-se que quase todos conseguiram identificar o que havia na caixa. Quando a resposta é dada sobre o porquê de terem acertado todos os objetos, apenas o Grupo 1 consegue utilizar uma estratégia que os outros grupos não observaram, que seria a comparação do peso das duas caixas além do som. Neste grupo há um aluno (Aluno 10) que apresentou a observação de utilizar o peso, além de ter apresentado respostas coerentes nos experimentos de nível 1, mostrando uma pequena evolução que sugere indícios de formação de espírito científico. 


\subsection{Atividade nível 2: densidade de um sólido não poroso}

No segundo ano do Ensino Médio participaram da atividade de densidade dos sólidos 17 alunos e, no primeiro ano, seis alunos. Como não foi observada diferença de respostas entre as duas salas, os dados obtidos serão analisados conjuntamente. Esses resultados semelhantes podem ser atribuídos ao fato de que a metade da turma do segundo ano era composta por alunos reclassificados do primeiro ano, portanto, possuíam praticamente o mesmo grau de conhecimento.

Os alunos possuíam três materiais para análise: prego, bolinha de gude e tampa de caneta. Inicialmente, foi realizada a leitura do roteiro experimental explicando cada passo do procedimento. Os alunos tomaram notas das massas de cada objeto, adicionaram $50 \mathrm{~mL}$ de água na proveta e anotaram os volumes inicial e final (após adicionarem o objeto). Para cada objeto foi realizado o cálculo da densidade com a ajuda da professora. Na sequência, os alunos anotaram suas conclusões e socializaram os dados obtidos a fim de saber se foram coerentes com o resultado experimental e, assim, discutirem o que ocorreu no experimento. A frequência das respostas obtidas encontra-se na Tabela 9:

Tabela 9 - Frequência das conclusões apresentadas pelos alunos em relação ao experimento sobre densidade

\begin{tabular}{|l|l|}
\hline Classificação das respostas & Frequência \\
\hline Coerente & 0 \\
\hline Pouco coerente & 0 \\
\hline Incoerente & 6 \\
\hline Não responderam & 17 \\
\hline
\end{tabular}

Fonte: Autoria Própria

Durante a resolução das contas de densidade, muitos alunos erraram a divisão e encontraram o valor errado da densidade do prego (menor do que o valor correto). Para a explicação de qual objeto era o mais denso, ainda se manteve o prego com maior densidade. A justificativa que os alunos utilizaram foi que o prego é um metal. De acordo com Bachelard (1996), o fato de os alunos utilizarem uma característica macroscópica para justificar, por exemplo, que o metal é mais denso por ser de ferro, nos dá indícios de que os alunos se encontram no estado concreto. Um outro exemplo de resposta descrito pelos alunos foi: 
"O prego é mais denso porque ele é de metal e possui mais massa" (Aluno 9)

Esta resposta mostra que os alunos ainda estão presos ao senso comum, que Bachelard (1996) chama de experiência primeira, ou seja, presa ao primeiro contato ou a conceitos previamente adquiridos. No trabalho de Maclin, Grosslight e Davis (1997) é abordado o uso da densidade e da fórmula matemática de densidade, mostrando que os alunos possuem dificuldades em realizar o cálculo, não só pela matemática em si mas também pela não compreensão de conceitos relacionados à densidade que estavam atrelados a conhecimentos do senso comum como, por exemplo, substâncias de densidades diferentes não se misturam. Durante a atividade aplicada, uma aluna encontrou os valores corretos, mas não entendeu o significado da densidade, explicando de forma inversa os valores obtidos. O interessante dessa aluna foi o fato de ela ter se atentado pela circunferência da tampa de caneta e que poderia entrar água dentro, deixando-a mais densa. A resposta da aluna encontra-se transcrita abaixo:

"Achei que o prego era mais pesado só que por ele ser menor e a tampa é mais pesada talvez por seu diâmetro". (Aluno 10)

Segundo Mortimer (2000), quando o aluno aprende apenas a relação matemática, ou seja, ele aprende a resolver a conta sobre densidade, não quer dizer necessariamente que ele tenha compreendido o conceito. Este fato pode ser aplicado a esta aluna que encontrou os valores corretos, mas não conseguiu relacionar com a teoria onde objeto era o mais denso, ou seja, ficou claro o conceito matemático, mas não o conceito químico.

O fato de 18 alunos não escreverem a conclusão mostra que eles não conseguem colocar no papel uma explicação para um fenômeno, apesar de argumentarem oralmente e participarem da atividade. Uma segunda explicação é que eles não entenderam o comando para escrever a conclusão de qual objeto era 
mais denso. Um terceiro motivo para não escreverem pode ser por acharem que não sabem explicar o que ocorreu durante a atividade.

\subsection{Atividade nível 4: Atividade chuva ácida}

Na semana anterior à aplicação da atividade investigativa sobre chuva ácida, a professora realizou a leitura de um texto, retirado do caderno do aluno, que explicava a formação da chuva ácida e o que ocorria em decorrência da queima de compostos a base de petróleo. Ao final da aula, a professora solicitou aos que alunos pesquisassem sobre algumas substâncias que causam chuva ácida, pois os conceitos seriam importantes para a aula experimental na semana seguinte. Durante a aula na semana posterior, os alunos receberam um texto explicando que havia ocorrido um vazamento de enxofre, resultando em chuva ácida. Por este motivo, um exemplo encontra-se no (APÊNDICE C). A partir da contextualização, foi solicitado que os alunos elaborassem uma hipótese do porquê que isso havia ocorrido. Abaixo, encontra-se a Tabela $10 \mathrm{com}$ a frequência de resposta e um exemplo de cada resposta é apresentada a seguir: 
Tabela 10 - Classificação e frequência das respostas em relação a elaboração da hipótese inicial pelos alunos sobre chuva ácida

\begin{tabular}{|c|c|c|}
\hline Tipo de Resposta & Frequência & Exemplo \\
\hline Coerente & 1 & $\begin{array}{l}\text { "Quando a água junta com as } \\
\text { substâncias de } \mathrm{SO}_{2} \text { ou } \mathrm{NO}_{2} \text { ou } \mathrm{CO}_{2} \text { vira } \\
\text { ácido, quanto mais } \mathrm{H} \text { (hidrogênio) mais } \\
\text { ácido será. Para identificar usa o ph } 7 \text {, } \\
\text { neutro, menor que sete é ácido e maior } \\
\text { que sete é básico." (Aluno 10) }\end{array}$ \\
\hline Pouco coerente & 9 & $\begin{array}{l}\text { "Pelo meu pouco saber os gases como } \\
\text { fumaça soltada pelos carros, motos e } \\
\text { caminhões são umas das principais } \\
\text { causas de chuva ácida. Também como } \\
\text { os reagentes químicos soltadas na } \\
\text { fumaça de fábricas e produtos químicos } \\
\text { que não são nocivos ao meio ambiente } \\
\text { que causa todos seus danos como a } \\
\text { chuva ácida." (Aluno 2) }\end{array}$ \\
\hline Incoerente & 3 & $\begin{array}{c}\text { Algumas consequências da elevada } \\
\text { emissão de } \mathrm{SO}_{2} \text {. O ar poluído pode ser } \\
\text { transportado e causar a chuva ácida. } \\
\text { (Aluno 12) }\end{array}$ \\
\hline
\end{tabular}

Fonte: Autoria Própria

A Tabela 10 apresenta os dados referentes à elaboração da hipótese sobre a formação da chuva ácida. A tabela foi dividida em três partes, sendo que na primeira coluna é apresentado o tipo de resposta que foi encontrada e classificadas em "coerentes", "pouco coerentes" e "incoerentes" Na segunda coluna são apresentados o número de alunos que participaram e as respostas referentes a cada tópico e, na última coluna, é mostrado um exemplo de cada tipo de resposta.

Pode ser observado que apenas um aluno apresentou uma hipótese coerente utilizando conceitos químicos. O mesmo mostra que entende que o $\mathrm{pH}$ de uma substância ácida é menor que sete e que os gases reagem com a água formando substâncias ácidas. Apesar de ser coerente a resposta, o aluno apresentou uma definição de ácido genérica, como pode ser observado neste excerto na transcrição "... quanto mais $\mathrm{H}$ (hidrogênio) mais ácido será...", mostrando que o aluno utiliza de concepções alternativas para explicar o fenômeno, ou seja, ele 
escolhe uma teoria de ácido base, generalizando a explicação e utilizando a mesma para todas as substâncias ácidas e básicas, Muchtar (2012).

A maioria dos alunos (nove alunos) que participaram da atividade apresentou respostas pouco coerentes, utilizando fatos do dia a dia para explicar a reação química. Estes alunos não citaram a reação desses gases com a água, como pode ser observado na tabela acima. O aluno 2, exemplificado acima, ao comparar que os gases liberados na combustão de automóveis serem os responsáveis pela formação da chuva ácida, mostra que ele ainda precisa de uma referência concreta para explicar um fenômeno.

De acordo com Bachelard (1999), o indivíduo que necessita recorrer a imagens concretas para explicar um fenômeno encontra-se no estado concreto. Observa-se que os alunos que apresentaram respostas pouco coerentes ainda estão presos à observação primeira, em outras palavras, veem um fenômeno e tentam explicar rapidamente com explicações genéricas.

Apenas três alunos apresentaram respostas incoerentes, onde não conseguiram explicar a formação da chuva ácida, seja por meio de conceitos, seja por meio0 de exemplos cotidianos, apresentando ideias desconexas.

Com relação à elaboração da hipótese, ficou evidente que os alunos não compreenderam o seu conceito. Neste sentido, Praia, Cachapuz e Gil-Pérez (2002b) discutem que a hipótese é articulada com o fenômeno em estudo, ou seja, por detrás da experimentação há uma hipótese que está sendo sujeita a um teste ou verificação. Dessa forma, os autores afirmam que a experimentação exige uma preparação teórica sólida a fim de que não sejam realizados testes ao acaso ou meras constatações que levem o sujeito a pensar que a hipótese não influencia no resultado obtido. Nessa perspectiva, os autores enfatizam a importância da hipótese, pois, por meio dela, é possível realizar questionamentos e até mesmo a elaboração de outras hipóteses.

A partir dos dados apresentados, não é observado nenhum questionamento ou afirmação que pudesse ser testado, uma vez que, de acordo com Popper (2004), a hipótese dever ser testável e/ou falseável. Nessa lógica, Praia, Cachapuz e GilPérez (2002a) sugerem que os professores utilizem estratégias de ensino que utilizem a observação, refletindo seu significado, além de levantarem questionamentos frente às hipóteses apontadas pelos alunos, a fim de que eles 
possam elaborar as mesmas de acordo com o aprofundamento teórico que eles possuem.

Uma outra explicação para as poucas hipóteses coerentes ou cópia das hipóteses dos colegas, de acordo com Suart e Marcondes (2009), seria de que o aluno apresenta esse comportamento pelo medo em responder algo diferente do que foi explicado pelo professor e ser intimidado por ele. Ao longo das análises das respostas apresentadas pelos alunos, percebe-se que eles ainda não dominam o conteúdo para elaborar hipóteses coerentes com matéria estudada.

O próximo passo é a elaboração do roteiro experimental para a verificação da hipótese inicial. A Tabela 11 apresenta o tipo de resposta apontada pelos alunos, bem como exemplos das mesmas.

Tabela 11 - Análise da capacidade elaboração de roteiro experimental utilizando a estratégia investigativa

\begin{tabular}{|c|c|c|}
\hline $\begin{array}{c}\text { Classificação da } \\
\text { resposta }\end{array}$ & Frequência & Exemplo \\
\hline Coerente & 3 & $\begin{array}{l}\text { "Colocaria a fita de pH no vidro, } \\
\text { prenderia a colher (espátula) na } \\
\text { tampa, colocaria pétalas de flor no } \\
\text { fundo do vidro, utilizaria fita isolante } \\
\text { para prender a colher e a fita de pH no } \\
\text { vidro, colocaria o enxofre em pó na } \\
\text { espátula e esquentaria ele um pouco } \\
\text { coma vela acesa e pronto)."(Aluno 13) }\end{array}$ \\
\hline Pouco coerente & 3 & $\begin{array}{c}\text { "Colocaria o enxofre dentro de um } \\
\text { vidro e em seguida a água e a fita } \\
\text { tornassol para mostrar que causa a } \\
\text { chuva ácida." } \\
\text { (Aluno 2) }\end{array}$ \\
\hline Incoerente & 7 & $\begin{array}{l}\text { "Colocamos primeiro a água e depois } \\
\text { misturamos o enxofre em pó e a vela } \\
\text { depois mexeu, colocou carvão e mediu } \\
\text { o pH." (Aluno 12) }\end{array}$ \\
\hline
\end{tabular}

Fonte: Autoria Própria

A Tabela 11 apresenta os dados referentes à elaboração do roteiro experimental utilizado para realizar o experimento de nível 4. A tabela foi dividida em três colunas, sendo que a primeira coluna mostra o tipo de roteiro apresentado que, 
a partir daí, foram classificados da seguinte forma: se foi coerente com o esperado, pouco coerente e incoerente. Na segunda coluna é apresentado o número de alunos respondentes para cada classificação. A terceira coluna apresenta um exemplo de cada tipo de procedimento: coerente, pouco coerente ou incoerente.

Observando as três respostas dos exemplos citados, pode-se observar que nas duas primeiras houve a preocupação dos alunos em medir $\mathrm{opH}$ da solução, mostrando que compreenderam que, se a solução formada possuía um pH ácido, precisaria de alguma forma ser identificado. Segundo Praia, Cachapuz e Gil-Pérez (2002b), para a preparação de um experimento é necessário ter alguma articulação entre hipótese e experimentação senão não há experimento. Os autores justificam que o sujeito não faz experimentos ao acaso, dessa forma, mesmo que não aparente uma linha de raciocínio clara para o leitor, para o aluno, o roteiro proposto faz sentido. Nesta linha de raciocínio é possível observar que o terceiro grupo não realizou um experimento propriamente dito, pois não selecionou o que iria utilizar para o experimento, apenas pegou todos os materiais e os colocou dentro do frasco e aqueceu para observar o resultado. Dessa forma, os alunos participantes do grupo provavelmente não compreenderam o comando ou não compreenderam o conteúdo e realizaram a atividade de qualquer jeito.

A partir da metodologia elaborada, os alunos realizaram os experimentos propostos e encontraram os seguintes resultados apresentados na Tabela 12 a seguir:

Tabela 12 - Análise dos resultados obtidos através da metodologia proposta pelos alunos

\begin{tabular}{|l|l|l|}
\hline $\begin{array}{l}\text { Classificação da } \\
\text { resposta }\end{array}$ & Frequência & Exemplo \\
\hline Coerente & 3 & $\begin{array}{l}\text { "A flor descoloriu e a fita de pH ficou } \\
\text { no número 2." (Aluno 13) }\end{array}$ \\
\hline Pouco coerente & 3 & $\begin{array}{l}\text { "A água ficou ácida entre o número 4." } \\
\text { (Aluno 2) }\end{array}$ \\
\hline Incoerente & 7 & "Ficou vermelho e fedendo." (Aluno 7) \\
\hline
\end{tabular}

Fonte: Autoria Própria

A Tabela 12 apresenta os dados referentes aos resultados obtidos durante a realização do experimento da formação da chuva ácida. Os dados obtidos foram 
classificados em "coerente", "pouco coerente" e "incoerente" na primeira coluna; a coluna seguinte é formada pela quantidade de alunos que apresentaram as respostas respectivamente classificadas; e a última coluna apresenta um exemplo de cada resultado exposto.

Apesar dos alunos apresentarem propostas pouco coerentes, conseguiram resultados satisfatórios, onde mostraram que a água fica com $0 \mathrm{pH}$ abaixo de 7 , dessa forma, confirmando que a água está ácida e poderia ser comparada com a situação problema inicial.

É interessante observar que maioria dos alunos apresentou resultados incoerentes, ou seja, não conseguiram identificar o pH ácido nem observar a descoloração da flor. Estes sete alunos foram os que apresentaram um procedimento incoerente mostrado na tabela anterior. Apesar de não realizarem um experimento propriamente dito, pois adicionaram os reagentes ao acaso, os alunos também não conseguiram justificar o porquê de "ficar vermelha a fita tornassol e fedendo".

Os alunos não realizaram a conclusão do experimento, isso pode ter ocorrido devido ao fato que os alunos entendam que o resultado já é a conclusão do experimento. Este dado mostra que não ficou claro para eles o que é conclusão e a importância da escrita detalhada para que o leitor possa compreender como foi executado o experimento. Isso mostra que deve ser dada uma atenção maior durante as aulas teóricas, tanto na explicação das etapas de levantamento de hipóteses, metodologia, resultados e conclusão quanto durante a atividade investigativa, além de ser feita a leitura com os alunos do passo a passo para ter a certeza de que todos entenderam e que não há dúvidas.

Deve ser ressaltado que, durante as aulas, os alunos eram lembrados constantemente da importância da clareza da hipótese para se fazer uma boa metodologia para atingir os resultados esperados. Também foi sempre lembrado durante as aulas a importância da escrita para que a professora pudesse compreender, durante a leitura, o que foi realizado durante o experimento.

No decorrer das aulas, foi esclarecida a importância do registro durante a realização do experimento como uma característica importante da natureza da ciência. Aparentemente, os alunos não possuem o hábito de escrever, principalmente o que observam ou o que entendem sobre um determinado assunto. 
Podemos extrapolar a falta de detalhes durante a atividade devido ao fato de as aulas serem em período noturno e os alunos já estarem cansados.

Considerando que esta foi a primeira atividade investigativa de nível 4 aplicada, foi dada uma maior autonomia para os alunos, os quais não estão acostumados com este tipo de estratégia. Em decorrência disso, o uso de estratégia diferente pode ter sido a causa de os sete alunos não conseguirem realizar a atividade com planejamento e determinada execução, já que estão acostumados a receberem respostas prontas, ou seja, não estão acostumados a pensar. Neste sentido, Suart e Marcondes (2009) também observaram que os alunos, durante a atividade investigativa, tiveram grande dificuldade, principalmente em propor objetivo e fazer previsões. As autoras sugerem que essa dificuldade ocorra devido ao baixo nível de liberdade que os alunos possuem em atividades de laboratório, especialmente em atividades "receita" onde apenas seguem o roteiro.

\subsection{Atividade nível 4: Atividade sobre conservação da massa.}

Quando a segunda atividade nível 4 é aplicada, observa-se uma melhora na formulação da hipótese, sendo esta coerente, corroborando com o procedimento aplicado e, consequentemente, obtendo o resultado esperado. Abaixo está apresentado, na Tabela 13, a quantidade de hipóteses classificadas em "coerentes", "incoerentes" e "pouco coerentes" e, respectivamente, as respostas obtidas. 
Tabela 13 - Análise da (capacidade) elaboração de hipótese utilizando a estratégia investigativa

\begin{tabular}{|c|c|c|}
\hline Hipótese & Frequência & Exemplo \\
\hline Coerente & 8 & $\begin{array}{r}\text { "Ela colocou comprimido na água e aconteceu } \\
\text { uma reação química transformando o } \\
\text { comprimido que está no estado sólido ele } \\
\text { dissolveu e ficou estado gasoso deixando o } \\
\text { copo mais leve." (Aluno 9) }\end{array}$ \\
\hline Pouco & \multirow{4}{*}{$\begin{array}{c}\text { "No processo quando Aline coloca o } \\
\text { comprimido no copo com água ele não mediu } \\
\text { o peso que ela esperava porque no processo } \\
\text { de ferver ele perdeu o seu gás efervescente. } \\
\text { Um simples processo de evaporação. Por } \\
\text { perca de peso do seu copo. Mas caso ela } \\
\text { tivesse vedado a boca do copo ela teria o peso } \\
\text { exato" (Aluno 2) }\end{array}$} \\
\hline Incoerente & 1 & $\begin{array}{c}\text { "Aline percebeu que o gás havia sido liberado } \\
\text { na água foi aquecer a água evaporar e ter } \\
\text { achado a maioria do sistema que a água e } \\
\text { comprimido foi o efeito do gás ir liberar na } \\
\text { água." (Aluno 14) }\end{array}$ \\
\hline
\end{tabular}

Fonte: Autoria Própria

Percebe-se que, neste segundo experimento, os alunos tiveram uma maior liberdade para escrever, onde esboçaram uma escrita com mais riqueza de detalhes. Deve ser ressaltado que escrever mais não significa que o aluno escreveu corretamente os conceitos envolvidos.

No primeiro exemplo, apesar de apresentar oito hipóteses coerentes na resposta descrita, o aluno utiliza a expressão "deixando o copo mais leve" para explicar a diminuição da massa após a reação. Portanto, observa-se que os alunos estão tentando explicar o fenômeno, porém, ainda não conseguem utilizar argumentos científicos.

Apenas quatro respostas se apresentaram como pouco coerentes. $\mathrm{Na}$ resposta apresentada na Tabela 13, pode ser observado que o aluno utiliza a palavra "ferver" ao invés de "efervescer" ou "liberar gás", utilizando concepções alternativas para explicar a liberação de gás, entretanto, ele identifica que, se o 
sistema estivesse fechado, haveria conservação da massa. A conservação da massa foi observada durante a primeira atividade realizada sobre transformações químicas, mostrando que esse aluno compreendeu que no sistema fechado a massa se conserva.

A resposta incoerente observada mostra que, aparentemente, o aluno não compreendeu 0 que ocorreu durante 0 experimento devido às sentenças desconexas, que podem ser observadas na Tabela 13.

Durante a elaboração do procedimento experimental, os alunos sentiram dificuldade em pensar um experimento utilizando apenas os materiais escritos na folha de respostas. Foram dados dez minutos para o início da socialização. Após esse período, os alunos não haviam feito porque não conseguiram pensar em algo (justificativa deles). Apenas um grupo conseguiu montar um roteiro que fosse pertinente para observação da conservação da massa fechando o sistema com uma bexiga. Os outros colegas utilizaram esse mesmo roteiro como base e realizaram adaptações. Apenas um grupo não utilizou bexiga e Erlenmeyer e, sim, o béquer com vinagre e bicarbonato. $O$ grupo pesou tudo antes e após a reação, então eles disseram: "fizemos igual à menina do texto e o gás evaporou!". Dessa forma, eles perceberam que não iriam observar a conservação da massa, todavia, o tempo havia acabado e não refizeram o experimento. $O$ resultado foi positivo, mesmo não realizando o experimento da forma esperada, porque conseguiram refletir sobre 0 conceito de sistema aberto e fechado. Um resumo das respostas dos alunos frente ao procedimento experimental planejado encontra-se na Tabela 14: 
Tabela 14 - Análise da capacidade de elaboração de procedimento experimental utilizando a estratégia investigativa

\begin{tabular}{|c|c|c|}
\hline $\begin{array}{c}\text { Classificação da } \\
\text { resposta }\end{array}$ & Frequência & Exemplo \\
\hline Coerente & 4 & $\begin{array}{c}\text { "Colocar vinagre no Erlenmeyer, bicarbonato } \\
\text { no balão, a reação química fará com que o } \\
\text { balão levante e o gás fica preso." (Aluno 11) }\end{array}$ \\
\hline Pouco coerente & 0 & \multicolumn{1}{c|}{-} \\
\hline Incoerente & 9 & $\begin{array}{c}\text { "No béquer colocamos o bicarbonato de sódio } \\
\text { com o ácido acético ao juntarmos os dois } \\
\text { houve uma fervura, é deixando tampado a } \\
\text { massa não derreteu fez render." } \\
\text { (Aluno 10) }\end{array}$ \\
\hline
\end{tabular}

Fonte: Autoria Própria

$\mathrm{Na}$ Tabela 14, pode ser observado que houve apenas quatro respostas coerentes. Apesar delas com a teoria, a escrita ainda é pobre em detalhes de como foi realizado o experimento.

Para os experimentos considerados incoerentes, que no caso foram oito atividades, estavam descritos apenas os materiais e não como foi realizado o experimento. Observando as respostas, é encontrada muita dificuldade por parte dos alunos em não realizarem a descrição do experimento com detalhes, onde muitos alunos colocaram apenas o que utilizaram no experimento e não como realizaram e nem os dados obtidos.

Outro fato que chamou a atenção foi que todos os alunos não descreverem as quantidades utilizadas de cada reagente, ou seja, colocaram quantidades aleatórias. Dessa forma, pode ser observado que ainda não ficou clara a necessidade de proporção entre os reagentes utilizados ao realizar o experimento, simplesmente os colocaram e esperaram reagir, não havendo sistematização prévia.

Ainda na resposta elencada na Tabela 14 classificada como incoerente, o aluno aborda uma concepção alternativa para explicar a liberação de gás, utilizando o termo "fervura". Quando o aluno utiliza a expressão "faz render", ele se refere ao bicarbonato que não reagiu durante o experimento.

Apenas sete alunos apresentaram uma conclusão coerente, mostrando que compreenderam que utilizaram o balão para que pudessem observar a conservação 
da massa. Não foram apresentadas respostas pouco coerentes ou incoerentes. Ao analisar a Tabela 15 abaixo, pode ser observado que seis alunos não apresentaram a conclusão do experimento, onde finalizaram a atividade apresentando apenas os resultados obtidos. Observa-se que, para o aluno obter os dados do experimento, já seria a conclusão da atividade.

Tabela 15 - Análise da capacidade de elaborar a conclusão do experimento

\begin{tabular}{|c|c|c|}
\hline $\begin{array}{c}\text { Classificação da } \\
\text { resposta }\end{array}$ & Frequência & Exemplo \\
\hline Coerente & 7 & $\begin{array}{c}\text { "Colocamos o balão para preservar o gás } \\
\text { e não perdemos a massa." (Aluno 2) }\end{array}$ \\
\hline Pouco coerente & - & - \\
\hline Incoerente & - & - \\
\hline Em branco & 6 & - \\
\hline
\end{tabular}

Fonte: Autoria Própria

As conclusões apresentadas pelos alunos não foram elaboradas, tampouco apresentaram alguma teoria para explicar a conclusão. Essa confusão de não relatarem ou confundirem a conclusão com o resultado experimental também é identificado no trabalho de Zohar (1998), no qual a autora justifica esses casos simplesmente pelo fato de não compreenderem o que é conclusão ou, o que ainda é mais problemático, não compreenderam o conceito por detrás do experimento e, portanto, não realizaram a conclusão do mesmo. Ruiz-Primo, Li, Tsai e Schneider (2010) observaram cadernos de laboratório de alunos e verificaram que quase metade dos dados apresentados não possuía suporte teórico. Os autores analisaram as respostas e acreditam que esta dificuldade que os alunos possuem pode se dar pelo fato deles não compreenderem a natureza da ciência, o que pode ser explicado devido a defasagem de anos anteriores ou até mesmo por não ter ficado realmente claro o comando durante a realização da atividade. 


\subsection{Análise da formação do espírito científico de alguns alunos}

Ao longo da aplicação das atividades investigativas, desde o nível 1 ao nível 4 , observa-se que, no geral, os alunos conseguem desenvolver um experimento a partir de um roteiro experimental dado, sendo que, inicialmente, eles não conseguiam fazer. Nota-se ainda que, em alguns casos, há dificuldade em correlacionar a teoria aprendida em sala de aula com a atividade experimental realizada. Muitas vezes, quando conseguem aplicar a teoria, ao explicarem com suas palavras, acabam utilizando animismos, concepções alternativas, além de não refletirem sobre o assunto para elaborar uma conclusão quimicamente adequada e de acordo com os conhecimentos apresentados durante as aulas teóricas.

Abaixo, será analisada a evolução de dois alunos, Aluno 2 e Aluna 13, que participaram das atividades de nível 4.Dessa forma, não serão consideradas as atividades 1 e 2 , pois estas foram utilizadas para que os alunos tivessem um primeiro contato com a estratégia investigativa, promovendo a participação dos mesmos em atividades experimentais. Esses dois alunos foram escolhidos porque participaram, de forma efetiva, da coleta de dados desde o início até a aplicação das atividades de nível 4. Os dados desses alunos estão sumarizados nos Quadros $4 \mathrm{e}$ 5. 
Quadro 4 - Sequência de respostas do Aluno 2 que participou de todas as atividades investigativas

\begin{tabular}{|c|c|}
\hline $\begin{array}{c}\text { Atividade } \\
\text { investigativa }\end{array}$ & Resposta \\
\hline Atividade 3 & $\begin{array}{c}\text { Explicação inicial: } \\
\text { Mauro pelo meu pouco saber os gases como fumaças } \\
\text { soltadas pelos carros, motos e caminhões são umas das } \\
\text { principais causas de chuva ácida. Também como reagentes } \\
\text { químicos soltadas na fumaça de fábricas e produtos químicos } \\
\text { que não são nocivos ao meio ambiente que causa todos seus } \\
\text { danos como a chuva ácida. E assim prejudicando a natureza. } \\
\text { *Gases responsáveis: } \mathrm{SO}_{2}, \mathrm{NO}_{2} \text { e } \mathrm{CO}_{2} \\
\text { Procedimento experimental: } \\
\text { Colocaria o enxofre dentro do vidro e em seguida a água e a } \\
\text { fita tornassol para mostrar a Mauro que causa a chuva ácida. } \\
\text { Conclusões } \\
\text { A água ficou ácida, pH4, fitinha. }\end{array}$ \\
\hline Atividade 4 & $\begin{array}{c}\text { Explicação inicial: } \\
\text { No processo quando Aline coloca o comprimido no copo com } \\
\text { água ele não mediu o peso que ela esperava porque no } \\
\text { processo de ferver ele perdeu o seu gás efervescente.Um } \\
\text { simples processo de evaporação.Por perca de peso do seu } \\
\text { copo. Mas caso ela tivesse vedado a boca do copo ela teria o } \\
\text { peso exato. } \\
\text { Procedimento Experimental: } \\
\text { Colocamos vinagre, folha de papel e bicarbonato e balão de } \\
\text { festa. } \\
\text { Conclusão: } \\
\text { Colocamos o Balão para preservar o gás e não perdemos a } \\
\text { massa, mas o papel não desmanchou. }\end{array}$ \\
\hline
\end{tabular}

Fonte: Autoria Própria

Observando o Quadro 4, nota-se que o aluno, na primeira atividade de nível 4, utilizou conceitos apresentados pela professora na aula anterior para explicar o que ocorreu durante a situação problema, utilizando-se de fórmulas químicas para explicar quais substâncias formam a chuva ácida. Infelizmente, ele não arriscou 
tentar explicar a formação da chuva ácida por meio dos gases que ele cita durante a explicação e, também, não deixou claro o que é uma substância ácida. A partir dessas observações, pode ser considerado que o aluno não compreendeu o conceito - e talvez sejam necessárias mais atividades para que ele internalize os mesmos - ou ele não sentiu a necessidade de utilizar esses conceitos para explicar a Mauro a relação entre a emissão dos gases "tóxicos" e a chuva ácida.

Para a elaboração do experimento o aluno, aparentemente, utiliza dados da situação problema: água, mais enxofre e a fita de $\mathrm{pH}$. Ao deixar durante um tempo no experimento, ele percebe a mudança de cor da fita e, ao comparar com o gabarito da caixa de fitas, notou um pH igual a 4, o qual ele identificou como ácido. A partir desses dados, percebe-se que o aluno, de alguma forma, internalizou a escala de $\mathrm{pH}$ identificando 4 como um valor que sinaliza ser um ácido.

$\mathrm{Na}$ segunda atividade, o aluno percebe a importância do meio estar fechado para observar a conservação da massa, porém não usa os conceitos quimicamente corretos, além de utilizar concepções alternativas como "ferver" para explicar a liberação de gás, ainda confunde a reação química com evaporação e conclui sua explicação dando um exemplo de como ela poderia ter chegado a mesma massa inicial: tampando o recipiente. Ainda na elaboração do experimento, o aluno é muito sucinto, não descreve como foi realizado e conclui que a massa se conservou devido ao fato de utilizarem o balão de festa para fechar o recipiente, mas não utiliza a balança para verificar se o que conclui é verdadeiro.

Bachelard (1996) atribui esses pensamentos rápidos sem explicações mais aprofundadas como observação primeira, a qual denomina como um obstáculo para a formação do espírito científico. Apesar de toda a dificuldade desses alunos, este, em especial, conseguiu, em partes, mostrar que a teoria aplicada ao experimento fez algum sentido para ele. Mesmo tendo explicações simplistas, ele conseguiu se fazer entender, tentou explicar a teoria mesmo utilizando concepções alternativas. Infelizmente, o estudante não se mostrou questionador e se apresentou "preso" aos dados que encontrou sem aprofundamento das conclusões. Todavia, o aluno demonstra interesse em fazer atividades experimentais, o que é positivo. Com a realização de mais atividades investigativas, pode-se instigar e aguçar a curiosidade, podendo torná-lo questionador, dessa forma, futuramente, acarretar na formação do espírito científico desse aluno. 
Outro caso que despertou atenção da professora/pesquisadora foi a aluna citada abaixo, pois esta estava no primeiro ano do Ensino Médio e foi reclassificada para o segundo ano, que seria o ano escolar ideal para a sua idade. Portanto, a aluna não teve os pré-requisitos contemplados do primeiro ano. Alguns conteúdos foram repassados pela professora, pois havia muitos estudantes na mesma. Apesar de conteúdos serem adaptados para que eles pudessem acompanhar a segundo ano, a todo momento era necessário retomar conceitos que foram apresentados no primeiro ano, porém, não com tanto aprofundamento. Mesmo com inúmeras dificuldades, a aluna em questão se destacou pelo interesse em resolver as atividades investigativas. Mesmo assim, infelizmente era, mesmo sendo faltosa e não conseguiu participar das atividades de nível 5, apesar de seu potencial. As respostas que a aluna apresentou durante as atividades investigativas encontra-se no Quadro 5: 
Quadro 5 - Sequência de respostas da Aluna 13 que participou de todas as atividades investigativas

\begin{tabular}{|c|c|}
\hline $\begin{array}{c}\text { Atividade } \\
\text { investigativa }\end{array}$ & Resposta \\
\hline Atividade 3 & $\begin{array}{c}\text { Explicação inicial: } \\
\mathrm{SO}_{2}+\mathrm{H}_{2} \mathrm{O} \rightarrow \mathrm{H}_{2} \mathrm{SO}_{4} \text { (ácido sulfúrico) } \\
\text { Procedimento experimental: } \\
\text { Colocaria a fita de } \mathrm{pH} \text { no vidro, prenderia a colher (espátula) } \\
\text { na tampa, colocaria pétalas de florno fundo do vidro, utilizaria } \\
\text { fita isolante para prender a colher e a fita de pH no vidro, } \\
\text { colocaria o enxofre em pó na espátula e esquentaria ele um } \\
\text { pouco a vela acesa e pronto. } \\
\text { Conclusão: } \\
\text { A flor descoloriu e a fita de pH ficou no número } 2 .\end{array}$ \\
\hline Atividade 4 & $\begin{array}{l}\text { Explicação inicial: } \\
\text { Houve uma liberação de gás que "escapou" do copo, que } \\
\text { explica a perca de massa faltante. } \\
\text { Procedimento experimental: } \\
\text { Colocar vinagre no Erlenmeyer, bicarbonato no balão, a } \\
\text { reação química fará com que o balão levante e o gás fica } \\
\text { preso. } \\
\text { Conclusão: } \\
\text { Experimento bem-sucedido pois o gás ficou preso no balão. }\end{array}$ \\
\hline
\end{tabular}

Fonte: Autoria Própria

Ao analisar o Quadro 5, nota-se que não houve explicação inicial, porém, a aluna conseguiu utilizar símbolos químicos para expressar a reação que ocorria entre o gás e água para a formação da chuva ácida. Diferente do primeiro aluno citado no Quadro 4, ela conseguiu explicar minimamente os passos que foram realizados durante o experimento. Quando é indagada sobre como pensou durante o experimento, a mesma responde que buscou experimentos na internet durante a semana (houve um intervalo de uma semana entre a aula sobre ácidos-bases e a atividade experimental). Apesar da aluna ter procurado "a resposta" na internet, foi a única da turma que se interessou em procurar e pensar sobre o experimento, ou seja, apresentou curiosidade. 
Bachelard (1996) denomina esse tipo de curiosidade como curiosidade ingênua, pois, durante a conclusão, a aluna apenas repete o resultado que observou na fita de pH, mas não explicou o fenômeno ou o porquê desse resultado, apenas se deu por satisfeita com o resultado que observou, sem questionar ou pensar sobre. Essas explicações rápidas já destacadas por Bachelard (1996) também são identificadas na segunda atividade. Apesar da aluna conseguir usar em sua explicação o termo correto: liberação de gás, em seguida, ela utiliza um animismo "escapou" como se o gás quisesse sair correndo do copo, não justificando que era uma reação química que estava ocorrendo na situação-problema. Em seguida, durante a elaboração do procedimento experimental, ela, sucintamente, lista os materiais a serem utilizados, mas não descreve o passo a passo utilizado no experimento anterior, ou seja, não conseguiu explicar a sua estratégia e, quando apresenta uma conclusão, apenas conclui que o experimento deu certo, pois o gás ficou preso no balão, isto é, também não conseguiu explicar numericamente como isso é feito.

Diante do exposto, em ambos os casos apresentados, os alunos mostram que, superficialmente, conseguem utilizar conceitos aprendidos em sala, mas ainda falta estruturar o pensamento durante a elaboração de um procedimento experimental e pensar criticamente em relação ao resultado obtido. Nas duas atividades apresentadas acima pelos dois alunos, é possível observar que eles compreendem que o resultado obtido é a conclusão do experimento. Esta observação se estende aos demais alunos da sala.

Realizando uma comparação desde o início da aplicação das atividades experimentais no mês de março, quando inicialmente não conseguiam realizar um experimento utilizando um roteiro experimental, até ao final da aplicação de atividades investigativas de nível 4 no mês de junho, isto é, em quatro meses, os alunos foram capazes de elaborar hipóteses ainda que suas respostas não fossem totalmente corretas, tentaram elaborar procedimentos experimentais, além de promoverem a interação e argumentação entre os alunos da classe e discussão dos dados obtidos pelos grupos. Observa-se uma evolução muito rápida, apesar da defasagem de anos anteriores e contexto escolar noturno em que foi realizada essa pesquisa, quando comparado, por exemplo, com estudos longitudinais como o de Kasseboehmer e Ferreira (2013). 


\section{CAPÍTULO 4}

Neste capítulo será realizada uma análise da atividade investigativa nível 5. Será analisado o espírito científico do ponto de vista de elaboração de raciocínios mais complexos por parte dos alunos, pois esse é o nível máximo de liberdade. Finalmente, será discutida a contribuição do uso de atividades investigativas de nível 5 em alunos do Ensino Médio.

\section{ANÁLISE DA EVOLUÇÃO DAS RESPOSTAS ELABORADAS PELOS ALUNOS DURANTE AS ATIVIDADES DE NÍVEL 5}

Quando os alunos foram convidados a participarem da atividade investigativa, elaborando um problema, realizando a elaboração da hipótese e criando uma solução para o problema, inicialmente, eles tiveram muita dificuldade, pois era a primeira vez que deveriam pensar por si só, sem respostas prontas. Como citado anteriormente, cinco grupos foram formados, porém, apenas dois participaram das quatro semanas de atividades, um grupo participou de três semanas de atividades e dois grupos realizaram apenas duas semanas de atividades.

A fim de verificar uma evolução do espírito científico, será analisado apenas os grupos que participaram durante três e quatro semanas, portanto, três grupos. Pode ser observado na descrição das atividades de nível 5 que os alunos possuem questões de pesquisa muito simples e, consequentemente, elaboraram hipóteses simples ou confundiram o procedimento experimental com a hipótese. 


\subsection{Apresentação das respostas elaboradas pelos alunos durante as atividades de nível 5}

\subsubsection{Apresentação das respostas elaboradas pelo Grupo 1 nas atividades de nível 5}

O grupo, inicialmente, confunde hipótese com o procedimento experimental, ou seja, não descreveram o que esperavam que iria acontecer na reação entre o refrigerante e o leite. A hipótese elaborada pelo grupo encontra-se a seguir:

"Vou misturar coca com leite e chaqualhar (sic) a cada 15 minutos e ver a reação que ocorrerá." (Aluno 1)

$\mathrm{Na}$ transcrição acima, nota-se a dificuldade do aluno em apresentar uma hipótese, pois ele inicia explicando que vai misturar refrigerante de cola com leite, porém, não descreve o que pensa que irá ocorrer quando as duas substâncias reagirem entre si. Aparentemente, o aluno ficou preocupado em descrever o que ele poderia visualizar, entretanto, não refletiu sobre as reações químicas que poderiam ocorrer. Outra dificuldade apresentada pelo Aluno 1 foi em explicar qual era 0 problema da sua pesquisa durante a entrevista, confundindo o problema científico citado pela professora com o problema referente ao fato de não ter dado certo o experimento. Ou seja, o aluno não compreendeu a pergunta sendo necessário reformular a questão, dessa forma, pode ser considerado que ainda não ficou consolidado o conceito de problema cientifico. Essa dificuldade pode ser observada no trecho da entrevista transcrita abaixo:

Professora: O que você acha que é problema? Defina o problema do seu projeto? Tente descrever o que você fez a cada semana.

Aluno 1: Problema é quando não dava certo ou aquilo que a gente planejava, alguns produtos a gente não conseguia talhar tirar a cor do leite que a gente queria. Professora: Então qual era a pergunta do seu trabalho?

Aluno 1: Qual o produto químico era mais ácido pra tirar a cor totalmente do leite? (sic). 
Após a professora reformular a pergunta, o aluno consegue compreender 0 pedido da professora e consegue descrever qual era o seu problema: usar uma substância para "descolorir" o leite.

Bachelard (1996) relaciona a capacidade de saber perguntar com a formação do espírito científico, visto que eles apresentaram muita dificuldade na elaboração da hipótese, pois apresentaram um procedimento experimental. Neste sentido, pode ser sugerido que o aluno apresentou mudança de estado do espírito científico.

Ao observar a dificuldade na elaboração da hipótese, isto é, se a hipótese não é bem elaborada, o restante do projeto fica comprometido pois não tem uma meta para ser alcançada. Nota-se que os alunos apresentam mais dificuldades como, por exemplo, elaborar o procedimento experimental e analisar os resultados para a elaboração da conclusão, como pode ser observado no Quadro 6 a seguir:

Quadro 6 - Resumo das respostas apresentadas pelo grupo 1 durante as atividades experimentais investigativas de nível 5

\begin{tabular}{|c|c|c|c|c|}
\hline & Teste 1 & Teste 2 & Teste 3 & Teste 4 \\
\hline 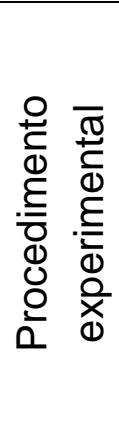 & $\begin{array}{l}\text { "Misturamos } \\
\text { coca com leite } \\
\text { numa garrafa } \\
\text { plástica de } \\
900 \mathrm{~mL} \text { e } \\
\text { chaqualhamos } \\
\text { a cada } 15 \\
\text { minutos". (sic) }\end{array}$ & $\begin{array}{l}\text { Colocamos } \\
\text { mais } \\
\text { refrigerante } \\
\text { do que leite } \\
\text { mas o leite } \\
\text { não talha. } \\
\text { (sic)" }\end{array}$ & $\begin{array}{c}\text { "Misturamos leite } \\
\text { com vinagre será } \\
\text { que qualha? } \\
\text { (sic)" }\end{array}$ & $\begin{array}{c}\text { "Misturamos leite } \\
\text { natural com } 3 \\
\text { limões e } \\
\text { chaqualhamos } \\
\text { (sic)." }\end{array}$ \\
\hline 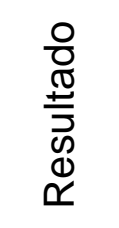 & Não talhou. & Não talhou. & $\begin{array}{l}\text { Mudança de cor, } \\
\text { separação das } \\
\text { fases, cheiro } \\
\text { azedo. }\end{array}$ & $\begin{array}{c}\text { Mudança de cor, } \\
\text { separação das } \\
\text { fases, cheiro } \\
\text { azedo. }\end{array}$ \\
\hline 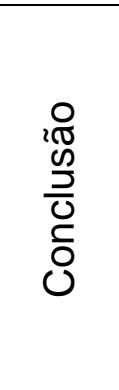 & $\begin{array}{l}\text { Leite com } \\
\text { coca não } \\
\text { talha. }\end{array}$ & $\begin{array}{l}\text { Mais coca do } \\
\text { que leite não } \\
\text { talha. }\end{array}$ & $\begin{array}{c}\text { Talhou o leite, } \\
\text { mas esse ácido } \\
\text { não foi suficiente } \\
\text { para descolorir o } \\
\text { leite. }\end{array}$ & $\begin{array}{c}\text { Chegamos a } \\
\text { conclusão que } \\
\text { depois dos } \\
\text { experimentos } \\
\text { feitos que o limão } \\
\text { é o mais ácido de } \\
\text { todos. }\end{array}$ \\
\hline
\end{tabular}

Fonte: Autoria Própria. 
Analisando o Quadro 6, observa-se que, em todos os experimentos, os alunos não apresentaram quantidade de reagentes, a proporção entre eles e quanto tempo ficaram agitando. Anotações do diário de campo revelam que, durante o primeiro teste, o grupo permaneceu, insistentemente, chacoalhando a garrafa desde o início do experimento, de 19:45h até as $22: 45 \mathrm{~h}$, aproxidamente, quando termina a última aula do dia, o que inicialmente deixou os alunos intrigados por não haver separação das fases e nem o leite ter ficado coalhado.

No encontro seguinte, os alunos retomaram o experimento e mudaram a sistemática, aumentando a quantidade de refrigerante adicionado, também sem sucesso. No terceiro encontro, os alunos adicionaram vinagre ao leite, que também não coalha, onde observaram que poderia ser o leite, já que estão usando leite longa vida (caixinha). No quarto encontro, utilizaram leite fresco e adicionaram o suco de três limões, aguardaram um tempo e, durante a aula, começou a separação da nata e do soro do leite, formando duas fases. Posteriormente, os alunos aguardaram até o final da última aula para observarem o quanto separaria. $\mathrm{Na}$ Figura 3 é possível observar a separação das fases:

Figura 3 - Grupo 1: Apresentação do quarto experimento (nível 5) no início (a esquerda) e no final da aula (a direita)

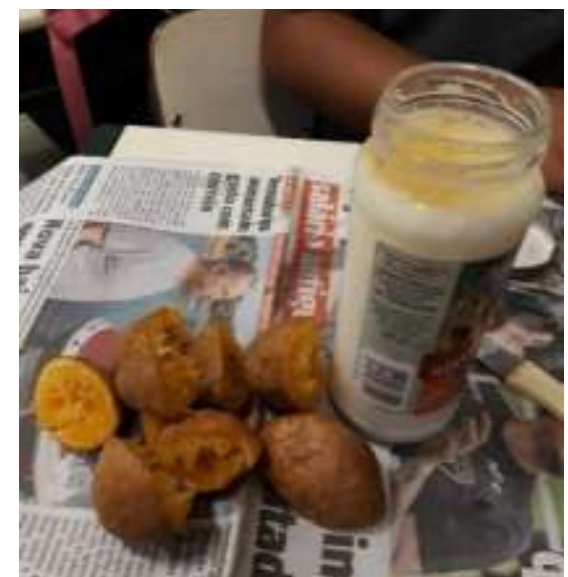

Fonte: Autoria Própria

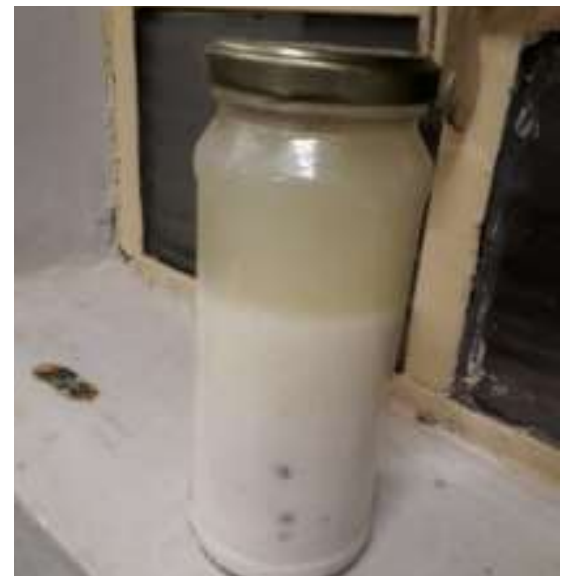

No último teste, os alunos conseguem, parcialmente, responder sua questão de pesquisa, que era identificar qual substância que "tira" a cor do leite.

Ao observar o Quadro 6, consta-se que os alunos demonstram muita dificuldade em apresentar um procedimento experimental e analisar os resultados obtido. A fim de compreender o que os alunos pensavam nas semanas entre os 
experimentos e durante as atividades, foram extraídos alguns trechos da entrevista realizada com o Aluno 1:

Professora: Como era durante a semana, você ficava pensando sobre o assunto até ter uma ideia? Quanto tempo, em média, você pensava nas atividades?

Aluno 1: "Eu pensei bastante quando não deu certo eu fiquei pensando naquilo que poderia mudar pra dar certo. Todo dia a tarde, no tempo livre. Ficava pensando naquilo que eu ia fazer buscando desse certo, pensei bastante umas meia hora (sic)."

Para que fosse possível ter mais indícios de que o aluno estava sendo sincero e não apenas respondendo para agradar a professora, foi solicitada uma redação, na qual continha perguntas e era esperado que o aluno seguisse aquele roteiro. Esse mesmo aluno realizou o texto e pode ser observado que corrobora com a fala do mesmo, de acordo com o trecho abaixo:

"Sim quando o experimento não deu certo fiquei pensando o porquê de não dar certo, e um meio de fazer com que aquilo que a gente buscava dar certo."

No Grupo 1, este foi o único aluno que respondeu a entrevista e realizou a redação. Recorrendo às anotações do diário de campo, foi observado que, durante as atividades, este aluno se mostrou o mais interessado, trazia o leite para a reação, realizava perguntas, se empenhava em ficar chacoalhando o leite para ver se o leite perdia a cor, que era o objetivo inicial, e não faltava durante as aulas experimentais.

Essas atitudes do estudante indicam que foi importante para ele a realização de atividades deste tipo e isso pode ser observado quando é relacionado à entrevista e à redação (texto) solicitada. Neste sentido, é apresentado, a seguir, um trecho da entrevista na qual o aluno confirma ter gostado de ter realizado as atividades investigativas:

Professora: Você gostou de realizar as atividades tanto da $1^{\underline{a}}$ parte da estratégia investigativa, quanto da $2^{a}$ fase em que vocês propõem o experimento? Se sim por quê?

Aluno 1: Foram legais, porque a gente tinha que pensar num jeito que buscasse aquilo dar certo, gostei de pensar. Achei legal e interessante. 
Professora: Você gostou de fazer essas atividades e faria novamente?

Aluno 1: Foi legal e interessante participar, achei, faria novamente.

Trecho do texto apresentado pelo Aluno 1:

"Eu gostei muito de realizar os experimentos pois fez com que a gente pensasse e realizasse os experimentos, é eu gostaria muito de fazer mais experimentos assim."

Ao observar os trechos de entrevista e da redação solicitada, nota-se que o aluno não se refere, em momento algum, sobre conceitos de átomos ou moléculas, ou reações químicas, mostrando que os alunos não conseguiram relacionar o conceito com a parte prática.

Durante a apresentação dos resultados apresentados no Quadro 6, pode ser denotado que os alunos não conseguiram correlacionar o que estavam observando macroscopicamente com o submicroscópico. De acordo com Johnstone (1991), para que o indivíduo consiga compreender um fenômeno, ele deve fazer a relação entre macro-simbólico-submicro, o que sugere que os alunos não conseguiram associar a teoria sobre ácido base com a reação que estava acontecendo entre o leite e as substâncias utilizadas para "descolori-lo".

Apesar da mudança de experimentos, o Grupo 1 conseguiu chegar em uma conclusão coerente, mas não necessariamente respondeu a sua hipótese inicial, pois a questão inicial era saber qual reação química acontece entre o leite e o refrigerante. $O$ interessante é que o grupo conseguiu utilizar substâncias que possuíam as mesmas características (ácida) e, ao final, encontraram uma substância que possuía uma característica mais ácida que coalhou o leite, culminando na separação das fases.

\subsubsection{Apresentação das respostas elaboradas pelo Grupo 2 nas atividades de nível 5}

O grupo 2, ao invés de escrever qual seria a hipótese, descreveu os materiais que seriam utilizados no experimento, apresentando a mesma dificuldade do primeiro grupo. A hipótese apresentada pelo grupo encontra-se a seguir. 
"Dois limões pela metade sendo que cada metade vai uma moeda e um clips com fios." (Aluno 2)

O grupo 2 apresentou os materiais utilizados no experimento ao invés de apresentar a hipótese, ou seja, ficou presos às observações macroscópicas, não conseguindo correlacionar a energia elétrica com a presença de íons no limão, além de não conseguir correlacionar a teoria com a observação experimental. O grupo era composto por três alunos e apenas dois realizaram o texto final e um aluno respondeu a entrevista.

Com a finalidade de perceber mudanças nos alunos, serão alisados trechos da entrevista e do texto solicitado. A fim de perceber se os alunos realmente confundiam a questão de pesquisa com problema comum será observado o trecho da entrevista que apresenta esta pergunta:

Professora: $E$ o que você acha que é problema em relação ao seu experimento.

Aluno 2: Acho que era o limão, alguns estavam diferentes não estavam na mesma qualidade.

Professora: O problema seria sua questão de pesquisa, o que você queria estudar. Aluno 2: Porque conseguimos acender um LED usando 4 limões?

Pode ser observado que o aluno, quando questionado sobre problema, se sente confuso e pensa qual foi o problema na realização do experimento e não sua questão de pesquisa. Quando a pergunta é refeita, o aluno a responde, porém, não responde a mesma questão de pesquisa escrita no Cronograma experimental. Apesar das dificuldades apresentadas acima pelo Aluno 2, o grupo conseguiu realizar alterações em seu procedimento experimental que fossem coerentes com a sua hipótese inicial, realizando todos os testes como pode ser observado no Quadro 7, a seguir: 
Quadro 7- Resumo das respostas apresentadas pelo grupo 2 durante as atividades experimentais investigativas de nível 5

\begin{tabular}{|c|c|c|c|c|}
\hline & Teste 1 & Teste 2 & Teste 3 & Teste 4 \\
\hline 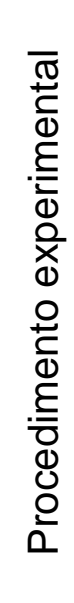 & $\begin{array}{l}\text { "Dois limões } \\
\text { pela metade } \\
\text { sendo que } \\
\text { cada metade } \\
\text { vai uma } \\
\text { moeda e um } \\
\text { clips com fios." }\end{array}$ & $\begin{array}{l}\text { "Cortamos o } \\
\text { limão e } \\
\text { colocamos fio } \\
\text { de cobre e o } \\
\text { led e a } \\
\text { moeda." }\end{array}$ & $\begin{array}{l}\text { "Vamos colocar } \\
\text { dois limão } \\
\text { (inteiro) na } \\
\text { frente e metade } \\
\text { do limão } \\
\text { maduro e } \\
\text { trocamos uma } \\
\text { moeda de } 5 \\
\text { centavos por } \\
10 \\
\text { centavos."(sic) }\end{array}$ & $\begin{array}{c}\text { "Colocamos } 4 \\
\text { leds e dois } \\
\text { limões cortados } \\
\text { pela metade." }\end{array}$ \\
\hline 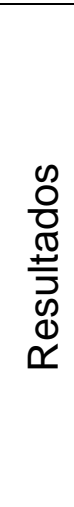 & $\begin{array}{c}\text { Conseguimos } \\
\text { ligar a luz, não } \\
\text { houve } \\
\text { liberação de } \\
\text { gás ou } \\
\text { temperatura. }\end{array}$ & $\begin{array}{c}\text { Conseguimos } \\
\text { deixar a luz } \\
\text { mais forte, } \\
\text { mas porem } \\
\text { acendemos } \\
\text { somente uma } \\
\text { lâmpada. }\end{array}$ & $\begin{array}{c}\text { Conseguimos } \\
\text { acender só um } \\
\text { led. }\end{array}$ & $\begin{array}{c}\text { Conseguimos } \\
\text { acender o led } \\
\text { mas só } 1 \text { led, } \\
\text { pois os limão } \\
\text { não contém } \\
\text { tanta } \\
\text { eletricidade } \\
\text { para acender } \\
\text { os leds. }\end{array}$ \\
\hline 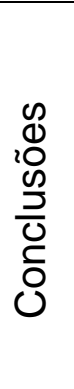 & $\begin{array}{l}\text { Conseguimos } \\
\text { realizar o } \\
\text { experimento." }\end{array}$ & $\begin{array}{c}\text { Não } \\
\text { conseguimos } \\
\text { acender mais } \\
\text { LED }\end{array}$ & $\begin{array}{l}\text { Adicionar mais } \\
\text { limão não } \\
\text { resolve nosso } \\
\text { problema pois } \\
\text { só } \\
\text { conseguimos } \\
\text { ligar } 1 \text { LED. }\end{array}$ & $\begin{array}{c}\text { Somente } 1 \\
\text { LED, } \\
\text { conseguimos } \\
\text { acender com } 4 \\
\text { limão sendo } \\
\text { eles verde e } \\
\text { maduros. }\end{array}$ \\
\hline
\end{tabular}

Fonte: Autoria Própria

Observando o Quadro 7, observa-se que o grupo persiste nos experimentos, fazendo variações sem explicar o fenômeno, mostrando uma curiosidade ingênua que Bachelard (1996) atribui ao estado concreto, ou seja, o aluno se preocupa apenas com a experiência, sem explicar os fenômenos que ocorrem.

No primeiro encontro, os alunos pegaram dois limões, os cortaram ao meio e utilizam uma moeda e um clips como polos para ligarem a lâmpada de LED, resultando o acendimento de apenas uma lâmpada. O segundo experimento utilizou 
fio de cobre e a moeda para acenderem a lâmpada de LED com apenas um limão, conseguindo acender uma lâmpada. No terceiro experimento, utilizaram dois limões inteiros mais e uma metade e observam que a luz de LED fica mais forte, porém, não acende os outros.

No quarto experimento, os alunos aumentaram o número de LEDs para quatro, tentaram acender as lâmpadas com apenas dois limões inteiros e observaram que apenas um LED também foi aceso. Neste caso, os alunos não conseguiram pensar no que faria aumentar a quantidade de energia elétrica envolvida, seja pelo caldo do limão devido a presença de íons ou pelos materiais utilizados como a moeda como polo positivo e o clips como polo negativo. Não foi observado, em momento algum durante o relato, entrevista ou escrita no Cronograma experimental, o uso de argumentos científicos para explicar o fato de não ser possível acender mais LEDs. As Figuras 4 e 5 a seguir apresentam um exemplo de experimento apresentado pelo grupo 2 :

Figura 4 - Grupo 2: Teste de condutividade do limão (nível 5)

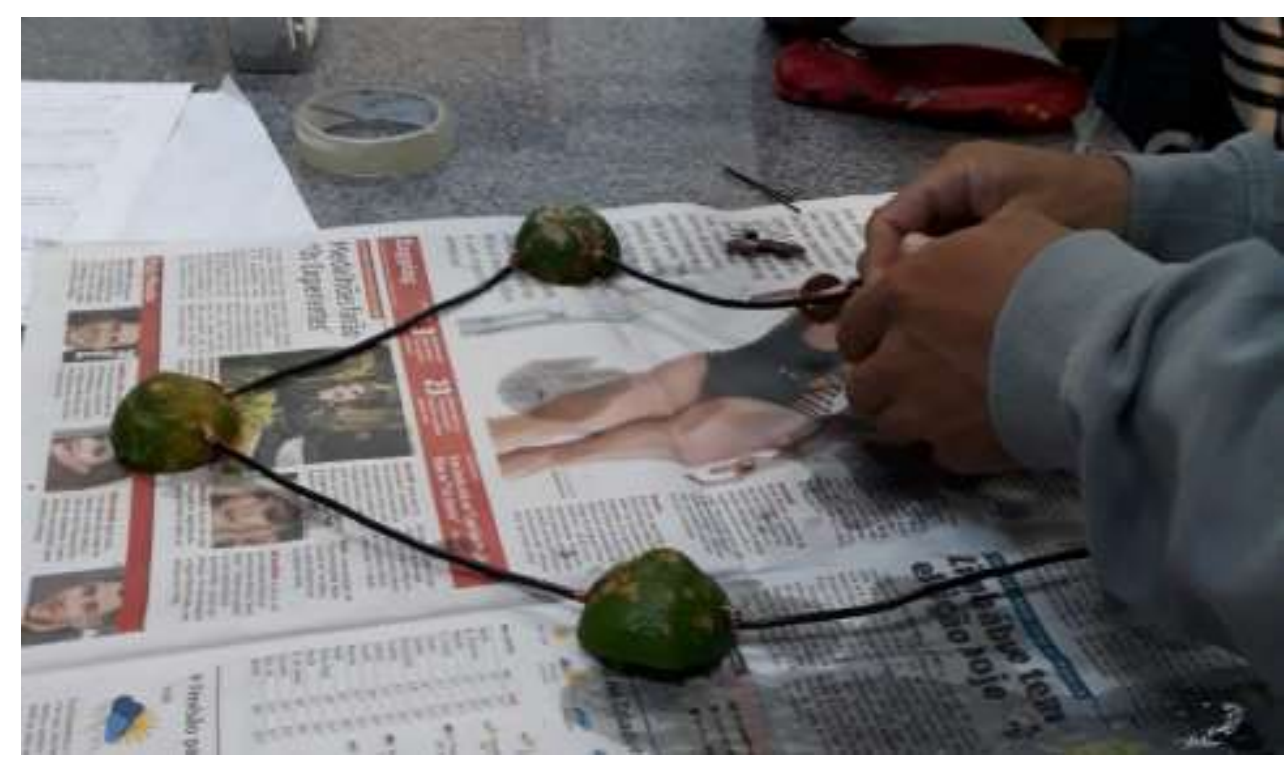

Fonte: Autoria Própria 
Figura 5 - Resultado do teste de condutividade com o acendimento do LED (nível 5)

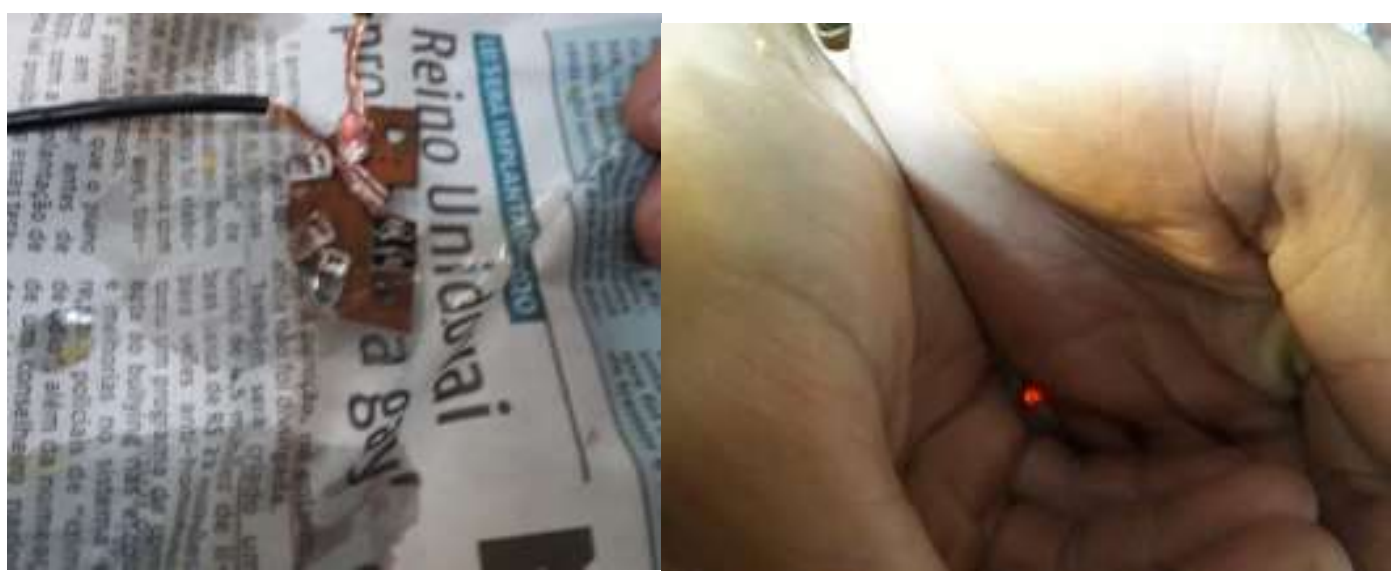

Fonte: Autoria Própria

Para a elaboração dos resultados, o Grupo 2 apresenta, na primeira resposta, evidências de reação que eles não perceberam durante o experimento, ou seja, para o aluno não houve reação. Nos experimentos seguintes, os alunos apenas se atentam ao acendimento da lâmpada, não refletindo sobre quais fatores que iriam influenciar no acendimento da lâmpada: a quantidade de sumo no limão e a presença de íons seriam fatores necessários para que as demais lâmpadas acendessem. A dificuldade em explicar o porquê é possível acender o LED com limão indica que não ficou claro para o aluno o que era para ser investigado. Neste sentido, a fim de observar indícios de formação do espírito científico, foi realizada a correlação entre a entrevista e o texto solicitado, onde foram encontradas as seguintes informações:

Na entrevista:

Professora: Entre um experimento e outro você ficava pensando sobre o experimento.

Aluno 2: Eu pesquisei um pouco, mas sempre achava a mesma coisa não tinha muita coisa. Eu acho que pelo limão estar maduro ou não, não sei, se ele estava mais ácido.

Professora: Quanto tempo você ficava pensando, uma tarde, uma manhã inteira? Aluno 2: Eu procurava pensar no dia da aula eu pegava para pesquisar. Professora: Você tentou pensar em reações químicas que estavam acontecendo? Aluno 2: Não. Só pensei se ele estava maduro ou verde.

No texto apresentado pelo aluno também é observado respostas genéricas, sem a presença de argumentos químicos para explicar o experimento. 
"Sim, fiquei pensando em como melhorar o experimento para termos um melhor resultado no final."

Apesar de não ficar claro 0 quanto 0 aluno se empenhou para explicar o experimento, ele confirma ter gostado de ter realizado atividades como esta, na qual o aluno propõe o experimento a ser estudado. Tanto o texto escrito pelo aluno como a entrevista apresentam afirmações neste sentido, como pode ser observado abaixo, respectivamente:

"Sim, gostei muito pois tenho curiosidades por este tipo de experiência que conduz energia ou motor que funciona sem combustível "somente com calor."

Professora: E agora na segunda fase que vocês propuseram o experimento. Qual é a sua opinião. O que você achou de participar de atividades assim?

Aluno 2: Achei mais legal porque você procura fazer o que você mais gosta.

Professora: Você gostaria de participar de projetos assim novamente? Por quê?

Aluno 2: Sim gosto de eletricidade, alguma coisa que tenha a ver com o motor, sim participaria eu gosto mais me identifico mais.

Apesar deste aluno ser o integrante do grupo que mais colaborou para o andamento do experimento, ele não apresentou mudanças significativas ao longo da realização das atividades investigativas, não procurou entender o que acontecia microscopicamente, não tentou explicar o que fornecia energia para que os LEDs fossem acesos e mostrou-se aparentemente apático.

Já o Aluno 3 não participou da entrevista, entretanto apresentou um texto sobre como foi a participação no projeto (este aluno era do mesmo grupo que o Aluno 2). Apesar da sua não participação na entrevista, seu texto traz observações interessantes que mostram que ele tentou explicar o que aprendeu e que também realizaria novamente atividades deste tipo. Abaixo é apresentado um trecho da redação do Aluno 3:

"Eu aprendi que o limão tem uma acidez que transmite entre $o$ ferro e a moeda e isso fez os LEDs acenderem... Eu gostei muito de 
realizar os experimentos queria que passasse mais atividades desse tipo, eu faria sim quantas for necessário para tirar minhas dúvidas e conclusões."

Apesar de o aluno apresentar concepções alternativas para explicar que há algo sendo enviado entre limão, fio, moeda e o clipe que faz com que o LED se acenda, quando comparado ao Aluno 2 que participou do mesmo grupo, o Aluno 3 tenta explicar o que aconteceu de forma simples, sem uso de argumentos científicos, enquanto o Aluno 2 não conseguiu explicar qual era o fenômeno que acontecia entre o limão e os demais acessórios.

O aluno se prontificar a realizar atividades deste tipo para tirar dúvidas e conclusões é interessante e mostra que, de alguma forma, aguçou a sua curiosidade. Todavia, nas aulas de Química, o aluno não mudou sua atitude em relação a sua participação durante as aulas. Apesar de poucas mudanças no seu comportamento e o deixar mais curioso, ainda não é possível identificar traços de formação do espírito científico.

Em relação às conclusões apresentadas, os alunos foram bem sucintos, como pode ser observado no Quadro 7, porém, ao longo das atividades, eles seguiram a mesma hipótese de identificar o que faz o limão conduzir eletricidade. Infelizmente, não conseguiram responder à hipótese, mas chegaram à conclusão de que não importa a quantidade de limões utilizados: conseguiriam acender apenas 1 LED. Neste caso, é possível observar que o fato de persistir na tentativa de realizar o experimento pode indicar algum indício de espírito científico.

\subsubsection{Apresentação das respostas elaboradas pelo Grupo 4 nas atividades de nível 5}

O Grupo 4 elaborou sua hipótese corretamente, visto que apresentaram uma afirmação que o grupo irá verificar, diferentemente dos outros dois grupos. A hipótese apresentada pode ser observada abaixo:

"A acetona dissolve o isopor." (Aluna 4) 
A Aluna 4 deste grupo apresentou o experimento com a acetona. Ela também não realizou o último experimento, participando apenas de três semanas de atividades. Expôs uma hipótese que poderia ser testada e escreveu a hipótese na forma de afirmação, diferentemente dos outros dois grupos que confundiram com o procedimento experimental.

A questão de pesquisa era pertinente, questionando se a acetona dissolve outros objetos, porém poderiam ter sido explorados conceitos de ligações químicas. Por infelicidade, este grupo não conseguiu aprofundar muito na discussão, visto que Química Orgânica só é apresentada aos alunos no terceiro ano. Os procedimentos experimentais elaborados pelo grupo, bem como os resultados e as conclusões apresentadas pelos alunos, encontram-se no Quadro 8, a seguir:

Quadro 8 - Resumo das respostas apresentadas pelo grupo 4 durante as atividades experimentais investigativas de nível 5

\begin{tabular}{|c|c|c|c|c|}
\hline & Teste 1 & Teste 2 & Teste 3 & Teste 4 \\
\hline 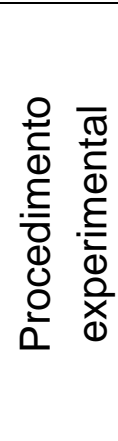 & $\begin{array}{l}\text { "Eu coloquei o } \\
\text { isopor sobre a } \\
\text { acetona pura e } \\
\text { a reação foi de } \\
\text { fervura e o } \\
\text { isopor foi } \\
\text { dissolvendo. } \\
\text { (sic)" }\end{array}$ & $\begin{array}{c}\text { "Se a } \\
\text { acetona } \\
\text { dissolve } \\
\text { copo } \\
\text { plástico?" }\end{array}$ & $\begin{array}{l}\quad \text { "Se a } \\
\text { acetona } \\
\text { dissolve } \\
\text { papel" }\end{array}$ & Não realizou \\
\hline 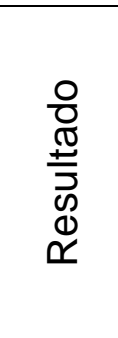 & $\begin{array}{c}\text { "Eu observei } \\
\text { que o isopor } \\
\text { dissolve a barra } \\
\text { que eu coloquei } \\
\text { dentro da } \\
\text { acetona" }\end{array}$ & $\begin{array}{c}\text { A acetona } \\
\text { enrugou um } \\
\text { pouco } \\
\text { dissolveu } \\
\text { menos que o } \\
\text { isopor. }\end{array}$ & $\begin{array}{c}\text { Nós } \\
\text { observamos } \\
\text { que } \\
\text { a acetona } \\
\text { não dissolve } \\
\text { o papel. }\end{array}$ & Não realizaram. \\
\hline 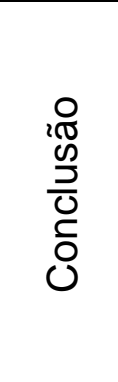 & $\begin{array}{l}\text { Sim foi válida } \\
\text { porque o } \\
\text { experimento } \\
\text { dissolveu o } \\
\text { isopor. }\end{array}$ & $\begin{array}{l}\text { Sim porque } \\
\text { foi válida } \\
\text { pois enrugou } \\
\text { um pouco } \\
\text { dissolveu } \\
\text { menos que o } \\
\text { isopor. }\end{array}$ & $\begin{array}{c}\text { Chegamos à } \\
\text { conclusão } \\
\text { quesó } \\
\text { dissolve } \\
\text { isopor. }\end{array}$ & Não realizou \\
\hline
\end{tabular}

Fonte: Autoria Própria 
Quando o grupo realiza a escrita do procedimento, não quantifica quanto de acetona é adicionado, não escreve o tamanho da placa a ser utilizada e ainda utiliza o termo "ferver" para explicar que houve liberação de gás. No encontro seguinte, o grupo procurou utilizar objetos semelhantes ao isopor para continuarem testando a hipótese inicial, utilizando um copo plástico. Os alunos novamente não quantificam o volume de acetona empregada na dissolução, não mediram a massa do copo e apenas colocam uma quantidade aleatória de acetona e adicionam o copo dentro. No terceiro teste, o grupo tentou reagir a acetona com o papel, utilizando novamente quantidade aleatória de volume de acetona e de tamanho de papel.

Como desde o primeiro experimento os alunos conseguiram observar que a acetona "dissolve" o isopor, os alunos não realizaram o quarto experimento. Um exemplo de experimento realizado pelo grupo testando a hipótese de que a acetona dissolve o isopor está representado abaixo na Figura 6.

Figura 6 - Grupo 4: Teste de dissolução do isopor em acetona (nível 5)

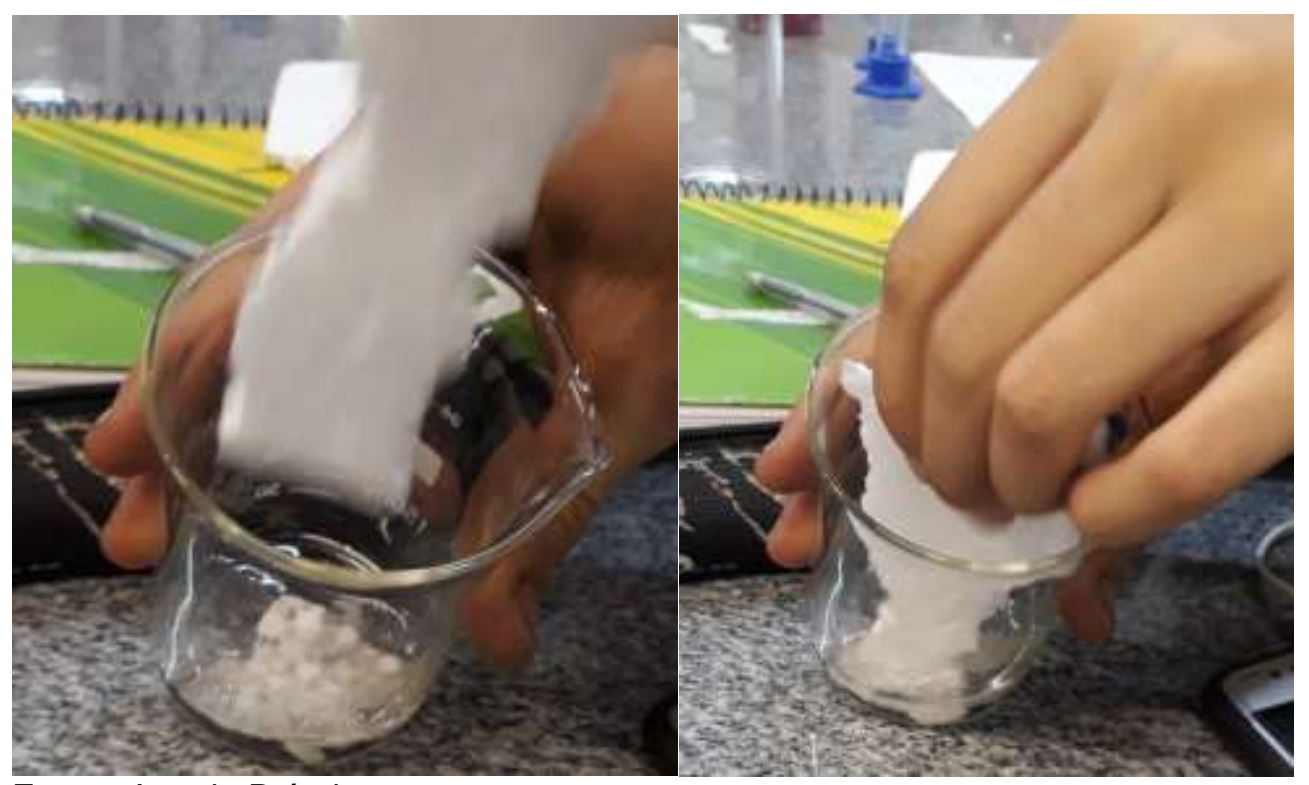

Fonte: Autoria Própria

Apesar da questão de pesquisa e a hipótese serem coerentes, a Aluna 4 não conseguiu discutir os resultados e se sentia satisfeita com a observação das características macroscópicas apresentadas durante o experimento. Quando questionada se procurou o porquê do isopor ser "dissolvido" pela acetona, a aluna calmamente diz "não!", ou seja, não houve curiosidade em compreender o 
fenômeno, apenas de descobrir se a acetona dissolve outros objetos. O grupo realizou os testes e se contentou com respostas do tipo: "dissolve", "sim" ou "não".

Durante a escrita do texto, fica claro que a Aluna 4 não pensou sobre 0 experimento. No roteiro da redação há uma questão onde é perguntado se o aluno ficou pensando no experimento realizado e quais modificações realizou, onde percebe-se que a aluna respondeu apenas metade da questão, explicando as modificações do experimento, como pode ser observado no trecho abaixo:

"Eu variei e percebi muita coisa diferente entre os dois: copo e o isopor, pois o copo ele deu uma encolhidinha e o isopor dissolveu pensamos muito pois queríamos pensar em algo legal." (Aluna 4)

Durante a entrevista, apesar de a aluna argumentar que se sentiu mais curiosa, também confirma que não pesquisou sobre o experimento, mostrando uma curiosidade ingênua. De acordo com Bachelard (1996), esse tipo de curiosidade indica que o sujeito se encontra no estado concreto. Esses dados podem ser observados na entrevista descrita abaixo:

Professora: Por que você participou de algumas atividades?

Aluno 4: Porque eu tenho dificuldade de fazer as atividades, porque não sei mexer muito com esses negócios de experimentos, fiquei com medo, não sei mexer com esses trecos que você usa.

Professora: Você não tentou pesquisar sobre o experimento?

Aluno 4: Não

Professora: Qual sua avaliação final sobre a inclusão de atividades de investigação em aulas de Química?

Aluno 4: Achei interessante

Professora: Você gostaria que as aulas de outras disciplinas ou as aulas de Química nos próximos anos fossem mais parecidas com este projeto?

Aluno 4: Sim porque são mais animadas, são importante. (sic).

Professora: Você achou importante fazer atividades assim?

Aluno 4: Achei importante a gente aprende mais, sim fez com que eu quisesse aprender mais química.

Professora: Na sua opinião, participar destas atividades ajudou você a fazer mais perguntas em sala de aula? Ou deixou você mais curiosa para aprender Química?

Aluno 4: Deixou mais curiosa, agora quero aprender mais.

Apesar de a Aluna 4 achar interessante atividades investigativas e deixaremna mais curiosa, não é observado o uso de termos químicos durante a escrita do 
texto e na entrevista realizada, também não foi observado, durante as aulas em paralelo com as atividades de nível 5, mudança de postura da aluna quanto ao fato de tornar-se questionadora e participar mais das aulas teóricas. Pelo contrário, ficou apática e faltava às aulas teóricas, o que pode justificar a dificuldade em relacionar os conceitos com a prática.

Os demais alunos que participaram da atividade não realizaram a entrevista e entregaram a folha do texto em branco, o que pode ser sugerido que não foi importante realizar as atividades investigativas.

Apesar de não haver uma discussão teórica esperada sobre os resultados obtidos pelo Grupo 4, eles conseguiram observar que a hipótese de o isopor ser dissolvido por acetona realmente ocorre já no primeiro experimento, porém, o grupo não consegue explicar o porquê. Nos experimentos seguintes, eles tentam utilizar outros materiais para observar se é possível dissolvê-los também. Os alunos concluem, no terceiro experimento, que a acetona dissolve apenas isopor e resolvem não realizar o quarto teste.

Em relação à conclusão apresentada pelo grupo, no Quadro 8, os alunos, nos dois primeiros experimentos, concordam que foram válidas as experiências, visto que, no primeiro, observaram a dissolução da acetona e, no segundo, um ligeiro enrugamento do copo; Ou seja, para eles, ocorreu a reação que esperavam. Já no terceiro experimento, os alunos concluem que não é possível dissolver o papel, mas não tentam explicar o porquê e, a partir daí, encerram os experimentos, se dando por satisfeitos com os resultados obtidos até então. Essa conformidade com respostas simples e rápidas que os alunos apresentaram ao longo das atividades, Bachelard (1996) caracteriza como curiosidade ingênua característica de seres que se encontram no estado concreto.

\subsubsection{Análises das respostas frente à formação do espírito científico}

Para os grupos 1 e 2 em estudo, pode ser sugerido que não ficou consolidado o conceito de hipótese, ou seja, os alunos não compreenderam o que era para ser feito. Neste sentido, é observada a necessidade de trabalhar com maior aprofundamento questões sobre natureza da ciência. O Grupo 4 apresentou uma hipótese coerente, entretanto teve os mesmos problemas dos demais grupos, que 
foram a dificuldade de elaborar um procedimento experimental e explicar os resultados obtidos.

Segundo Moss (2001), essas dificuldades de determinação da hipótese são detectadas devido a uma falta de preparação anterior dos alunos sobre natureza da ciência antes de se aplicar atividades experimentais, ou seja, se o aluno não compreender o que é fazer ciência e entender que é necessário pensamento crítico, raciocínio lógico e saber argumentar, ele não vai entender o que é levantar uma hipótese.

Devido ao tempo de coleta de dados e, em paralelo, cumprir a demanda de matéria prevista para o ano letivo, realmente foi trabalhada pouca a questão de levantamento de hipóteses e natureza da ciência. Para Bachelard (1996), um indício de formação do espírito científico pode ser identificado a partir do momento em que o indivíduo sabe perguntar. Se o aluno souber perguntar, ele consegue levantar uma hipótese e, ao mesmo tempo, argumentar se sua hipótese é coerente ou não.

Após a elaboração da hipótese, os alunos deveriam realizar o procedimento experimental. Segundo Hofestein e Lunetta (2003), durante uma atividade investigativa, é necessário que o aluno faça um planejamento do procedimento, o que não é possível ser observado. Os alunos não utilizam uma estratégia com quantidade de materiais a serem utilizados e não descrevem a sequência de adição dos reagentes, portanto, não há uma sistemática.

Bachelard (1996) caracteriza esse obstáculo como observação primeira, visto que ao longo das atividades descritas, os alunos apenas realizam o experimento e se contentam com o resultado que observam, sem pensarem criticamente o resultado obtido, apenas aceitaram respostas simples e se deram por convencidos de que estava respondido ou realizado o experimento.

Ao comparar os três grupos, percebe-se que eles possuem algo em comum: o fato de não apresentarem argumentos químicos para tentarem explicar o que eles estão vendo macroscopicamente. $O$ fato de os alunos não conseguirem explicar o fenômeno que ocorre no experimento realizado sugere que não possuem domínio do conteúdo para explicar a reação química.

Essa mesma dificuldade observada neste trabalho foi também encontrada no trabalho de Ferreira, Hartwig e Oliveira (2010), no qual os autores observaram que os alunos escrevem sucintamente o procedimento experimental.Os autores 
acreditam que pode ser devido à dificuldade conceitual atual ou de anos anteriores. Uma outra hipótese poderia ser o fato de que não compreenderam o que era para ser escrito e desenvolvido no campo a ser preenchido.

Estas dificuldades relatadas anteriormente corroboram com as observações realizadas durante a atividade experimental, embora tenham sido discutidos os conceitos em relação às substâncias ácidas e básicas em aulas anteriores à atividade experimental de nível 4, e retomadas durante as atividades de nível 5, porém os alunos não conseguiram correlacionar a teoria com a prática. Portanto, não foi possível observar evolução durante a elaboração do procedimento experimental dos três grupos em estudo.

Após a realização do experimento, os alunos realizaram as anotações no instrumento Cronograma Experimental. Ao observar a respostas, é notado que os grupos não conseguiram discutir os resultados obtidos, ficando presos às observações macroscópicas. Também não conseguiram utilizar conceitos químicos para explicar os resultados e a escrita apresentada é muito sucinta, sem riqueza de detalhes.

No trabalho de Ferreira, Hartwig e Oliveira (2010), os autores observaram que os alunos apresentaram dificuldades ao realizarem anotações referentes aos resultados. Apesar de encontrarem os dados corretos, não conseguiram assimilar com a teoria ou fundamentar esses dados com suporte teórico, sendo assim, os autores sugerem que esta dificuldade é particularmente encontrada quando há o uso do método tradicional, pois não há a correlação entre os dados e a teoria utilizada. Perren (2004) analisou respostas de alunos que utilizaram questões qualitativas e observaram dificuldades conceituais, o que o fez acreditar que os alunos podem não ter compreendido os conceitos químicos.

O fato de não pensarem no experimento e apresentarem observações macroscópicas sem reflexão do ocorrido corrobora com as afirmações realizadas anteriormente sobre a observação primeira, caracterizada por Bachelard (1996) como sendo um obstáculo para formação do espírito científico que impede o aluno de ser crítico e pensar além. Dessa forma, pode-se sugerir que os alunos se encontram no estado concreto.

As conclusões apresentadas pelos grupos, na verdade, são observações dos experimentos realizados, não há uma reflexão crítica dos resultados obtidos e não é 
observado uma resposta a hipótese inicial. No trabalho de Zohar (1998), a autora também observa que os alunos possuem dificuldades sobre separarem os resultados da conclusão. A partir de testes realizados com alunos durante as aulas de biologia, conclui-se que se os alunos não conhecem a teoria por detrás do experimento, portanto, eles não compreendem o que está ocorrendo microscopicamente, tornando difícil a diferenciação entre resultados e conclusão. A autora explora também a lacuna que existe durante a realização de experimentos na escola, que não fazem essa correlação entre teoria e prática, ou seja, talvez não tenha ficado clara a teoria, dessa forma, os alunos não conseguem extrapolar para a prática.

A partir do exposto, conclui-se que os dados são muito sutis para afirmar que houve alguma formação de espírito científico, porém há indícios de que os alunos ainda encontram-se, de acordo com a epistemologia de Gaston Bachelard, no estado concreto. Para tanto, neste sentido, não é possível afirmar se houve alguma evolução, porém, foram despertados a curiosidade e o interesse pela disciplina, que são fatores positivos, pois a Química é estigmatizada por muitos como sendo de difícil compreensão e muito distante da realidade da população em geral.

\subsubsection{Considerações sobre a aplicação da estratégia investigativa de nível 5 e possibilidades de estudos futuros}

Apesar dos esforços dos alunos em realizarem as atividades investigativas de nível 5, era esperado que não pudesse ser observado a formação do espírito científico, principalmente devido a defasagem de anos anteriores, além do fato de não estarem acostumados a pensar cientificamente. Em trabalhos longitudinais, como o de Kasseboehmer (2011), com aplicações de atividades de nível 4, também não foi observada a formação do espírito cientifico, portanto, este estudo avança no sentido de que houve a aplicação do nível 5 em aulas regulares de Química, na qual há a execução do nível de maior grau de liberdade, além de não haver nenhum artigo na literatura envolvendo o máximo de abertura de investigação em alunos de Ensino Médio.

Outro avanço, comparado ao trabalho de Kasseboehmer (2011), foi que este estudo realizou uma intervenção externa, enquanto neste trabalho a aplicação ocorre pela própria professora da turma, ou seja, ocorre a intervenção dentro do 
cronograma elaborado previamente pela professora, em um ambiente real de ensino e aprendizagem.

Neste sentido, houve a necessidade de mudança da prática pedagógica da professora para aprender a aplicar a estratégia investigativa em suas aulas, por um ano, antes da coleta de dados finais. Após a aplicação desta estratégia para a coleta de dados, foi possível incorporá-la na prática pedagógica cotidiana, além de disseminar a estratégia investigativa para outros colegas de áreas correlatas.

Ainda no sentido do aprimoramento da prática pedagógica, este estudo se destaca dos demais visto que, no Brasil, são encontrados poucos trabalhos na forma de pesquisa-ação como os de Felcher, Ferreira e Folmer (2017) e Reigada e Reis (2004). No exterior, foi observado que a pesquisa-ação é mais frequente, porém, na forma de grupo de estudos, sendo realizada com vários professores e acompanhados pela universidade por um longo período, como foi observado nos estudos de Solomon, Duveen e Scot (1992), Eilks e Markic (2011).

Além de todas essas contribuições citadas anteriormente, este trabalho cria abertura para explorar outros âmbitos futuramente como, por exemplo, a questão motivacional aliada ao uso da estratégia investigativa. Ao longo do trabalho, notouse que muitos alunos alegaram que gostaram de participar do projeto e que gostariam de realizar mais atividades como as que foram aplicadas durante o ano letivo. Neste sentido, Bachelard (1996) destaca a predisposição para abstração como um fator importante para atingir a abstração em si. Nesse sentido, outros trabalhos poderiam elaborar atividades que contribuam para investigar quais os aspectos psicológicos que movem estes alunos a terem a curiosidade pelos experimentos e pela ciência em si, diferentemente deste trabalho em que foram construídos instrumentos que fossem possíveis de investigar do ponto de vista conceitual. 


\section{CAPÍTULO 5}

Neste capítulo será descrito o caminho trilhado durante a aprendizagem da aplicação da estratégia investigativa em sala de aula, bem como a sua importância para este trabalho.

\section{A FORMAÇÃO CONTINUADA E A PESQUISA-AÇÃO}

Para muitos professores, a ideia de renovar a prática os deixa apreensivos, tanto que professora e pesquisadora deste trabalho também sentiu essa primeira dificuldade. Inicialmente, a mesma se sentia incomodada com o fato de os alunos não aprenderem, sentirem dificuldade durante as aulas e, muitas vezes, chegou a pensar que o problema era com a sua metodologia ou de cunho pessoal. Em um dia de inquietude, procurou a professora Ana, que Ihe apresentou a linha de pesquisa sobre o uso da estratégia investigativa e percebeu que poderia ser um bom aliado para as aulas de Química.

Para que fosse possível aprender e ter segurança em aplicar a estratégia investigativa na sala de aula, foram executados oito experimentos investigativos em escolas. Esses experimentos eram provenientes da "Experimentoteca" do Centro de Divulgação Cientifica e Cultural (CDCC), onde os roteiros foram elaborados por alunos do Programa Institucional de Bolsa de Iniciação à Docência (PIBID) e necessitavam de uma validação para saber se era possível a aplicação dessas atividades em sala de aula. Para tanto, a aplicação ocorreu em duas escolas particulares e uma estadual, durante o ano letivo de 2016. Com a intensa aplicação das caixas de experimentos do CDCC no modo investigativo, foi possível determinar uma média de tempo para cada etapa da atividade, além de tornar a professora/pesquisadora mais segura para a aplicação das atividades investigativas para o estudo piloto e a coleta de dados.

A maior dificuldade encontrada durante a aplicação das atividades foi não poder dar dicas para os alunos durante a sua aplicação. Ao mesmo tempo em que ocorriam esses questionamentos, era necessário elaborar questões que os fizessem analisar os seus raciocínios, devolvendo o questionamento para os alunos. 
Outra dificuldade encontrada foi que as aulas em que foram aplicadas as atividades do CDCC eram durante o dia, portanto, eram aulas de 100 minutos de duração. Porém, a coleta de dados ocorreu no período noturno, em aulas de noventa minutos, sendo necessário reorganizar todo o cronograma para que pudessem ser realizadas as atividades investigativas.

Durante a coleta, houve o imprevisto dos alunos do primeiro ano terem sido reclassificados para o segundo ano. Dessa forma, foi necessária uma adaptação curricular para o segundo ano, visto que a maioria dos alunos era proveniente do primeiro ano, portanto, não teria os conhecimentos prévios necessários para o prosseguimento durante as atividades investigativas.

A pesquisa-ação apresentada neste trabalho se mostrou positiva, pois houve a mudança na prática pedagógica da professora, introduzindo novas estratégias de ensino nas aulas de Química. As atividades aplicadas em sala foram adaptadas ao Currículo, mostrando que é possível sair da aula tradicional no ensino público com poucas condições de infraestrutura. Outro resultado proveniente desta pesquisaação, aliada ao uso de novas estratégias, é o fato de os alunos tornarem-se ativos no processo de aprendizagem, o que refletiu nas notas das avaliações e em maior participação em sala de aula.

Dessa forma, este trabalho se torna relevante, frente ao cenário educacional brasileiro, devido ao fato de ter sido realizado em uma escola pública, onde é a realidade majoritária de muitos alunos brasileiros, além de motivar outros professores da rede a realizarem esse movimento de mudança e contribuir para a melhoria do ensino público. 


\section{CAPÍTULO 6}

Neste capítulo, serão abordadas as conclusões e as considerações finais relativas à implantação da estratégia investigativa nas aulas de Química, em alunos do Ensino Médio, para a formação do espírito científico.

\section{CONCLUSÕES E CONSIDERAÇÕES FINAIS}

O uso da abordagem investigativa nas aulas de Química foi relevante para a aprendizagem, motivando os alunos além de instigar a curiosidade para aprender ciências, em especial a Química. Os alunos apresentaram dificuldades, visto que, para muitos deles, era a primeira vez que realizavam experimentos e grande parte apresentava defasagens de anos anteriores, principalmente os estudantes que estavam no segundo ano, onde a maioria foi reclassificada sem cumprir o primeiro ano do Ensino Médio.

Apesar das demandas escolares, os experimentos foram realizados inicialmente em sala de aula e, após o andamento da coleta de dados, o diretor da escola reativou o laboratório de Química para que a coleta tivesse andamento. Após a coleta de dados, o diretor observou que esses alunos tiveram mudança de comportamento após as aulas experimentais, ou seja, de alguma forma a aplicação deste trabalho foi positiva para esses alunos.

Durante o percurso das atividades investigativas desde o nível 1 até $\circ 4$, percebe-se que os alunos não utilizaram argumentos relevantes do ponto de vista científico, como pode ser observado principalmente durante as atividades de nível 4, na qual o aluno possui uma maior autonomia. Este fato é perceptível porque eles não representaram adequadamente o planejamento de estratégias e a resolução do problema. Notou-se que eles possuem dificuldades em selecionar uma evidência significativa que corrobore com os modelos científicos. Dessa forma, como não conseguem planejar o experimento de forma coerente, consequentemente tiveram dificuldades para chegar a uma conclusão significativa, sendo que, muitas vezes, a conclusão foi confundida com o resultado experimental obtido. Apesar dessas 
dificuldades e toda a problemática do ensino noturno, as atividades de nível 1 a 4 podem ser realizadas dentro do contexto escolar sendo adaptáveis ao currículo.

Ao ser implementado o nível 5, o que é inédito o uso desse grau de liberdade em sala de aula, os alunos apresentaram dificuldades em elencar um problema a ser estudado, provavelmente isso ocorreu devido à falta de maturidade. Após a escolha de seus problemas a serem estudados, foi constatado empenho para a realização do experimento, porém, em alunos pontuais. Outros acharam muito difícil ficar pensando e deixaram as atividades de lado, chegando a faltar no dia da aula. Como as atividades de nível 5 exigiam muito dos estudantes, tanto intelectualmente quanto teoricamente, apesar da deficiência de conceitos prévios, o que pode ter influenciado nos dados obtidos, pode-se concluir que o tempo de estudo foi muito curto para verificar a formação do espírito científico. Ficou evidente que, em ambas as turmas, havia alunos curiosos e que não se mostravam durante as aulas de Química, mas que durante as atividades experimentais sempre estavam presentes e participativos.

Afirma-se que é possível aplicar o nível 5 em sala de aula com ressalvas. Primeiramente, deve ser trabalhado o nível 4 por um tempo maior, a fim de que os alunos possam ter a habilidade de elaborar um procedimento experimental, tal como um cientista realiza. A partir da elaboração do roteiro experimental, é possível extrair os resultados sempre suportados pela teoria, dessa forma, os alunos conseguirão elaborar as conclusões do experimento. A partir do momento em que o nível 4 está consolidado, pode ser aplicado o nível 5, entretanto deve ser escolhido pelo professor um tema mais restrito a fim de orientar melhor os estudantes, uma vez que o fato de ter deixado muito aberto resultou em tantas possibilidades que os estudantes não conseguiam definir um problema em si.

Dessa forma, foi importante a implementação da estratégia investigativa em diferentes níveis, na qual o aluno se torna ativo no processo de ensino e aprendizagem, sendo capaz de argumentar, formular hipóteses, elaborar experimentos e realizar conclusões, ainda mais em um cenário em eram alunos desacreditados pelos demais professores. Apesar dos dados serem insuficientes para concluir se houve ou não a formação do espírito científico, de alguma forma eles foram escutados pelo menos uma vez durante a realização do projeto. 
Como professora, conseguiu implantar, na prática docente, atividades investigativas durante as aulas de Química, aprendeu que a análise do erro é importante e o que ele nos diz enquanto docente. Houve mudança em sua prática pedagógica, que era apenas expositiva e totalmente tradicional, onde apresentava conteúdo, lista de exercícios e prova. Percebeu que, quando o aluno faz parte desse processo, ele tem liberdade para perguntar, refletindo nas notas, na capacidade de argumentar durante a explicação de um conteúdo, tornando-os questionadores, e a professora se tornando uma profissional melhor. 


\section{REFERÊNCIAS BIBLIOGRÁFICAS}

ABRAMOVAY, M.; CASTRO, M. G. Ensino médio: múltiplas vozes. Brasília: Unesco, 2003. p. 241-247.

ALLEN, J. B.; BARKER, L. N.; RAMSDEN, J. H. Guided inquiry laboratory. Journal of Chemical Education, Washington, v. 63, n. 6, p. 533, 1986.

ANTUNES, M. T. Ser protagonista: química. 2. ed. São Paulo: Editora SM, 2013.

ARTIGUE, M.; BLOMHØJ, M. Conceptualizing inquiry-based education in mathematics. Zentralblatt for Didaktik der Mathematik, Heidelberg, v. 45, n. 6, p. 797-810, 2013.

BACHELARD, G. A formação do espírito científico. Rio de Janeiro: Contraponto, 1996.

BACHELARD, G. O novo espírito científico. Rio de Janeiro: Tempo Brasileiro, 2000.

BARBIER, R. Pesquisa-ação. Brasília: Liber Livro Editora, 2007.

BARKER, V.; MILLAR, R. Students' reasoning about chemical reactions: what changes occur during a context-based post- 16 chemistry course? International Journal of Science Education, Oxon, v. 21, n. 6, p. 645-665, 1999.

BENITE, A. M. C.; BENITE, C. R. M. O laboratório didático no ensino de química: uma experiencia no ensino público brasileiro. Revista lberoamericana de Educación, Madrid, v. 48, n. 2, p. 9, 2009.

BOGDAN, R.; BIKLEN, S. Investigação qualitativa em educação: fundamentos, métodos e técnicas. Portugal: Porto Editora,1994.

BRASIL. Ministério da Educação. Secretaria de Educação Básica. Diretoria de Currículos e Educação Integral. Diretrizes curriculares nacionais gerais da educação básica. Brasília: Ministério da Educação, 2013.

BRASIL. Presidência da República. Casa Civil. Subchefia para Assuntos Jurídicos. Emenda constitucional no. 14, de 12 de setembro de 196. Modifica os arts. 34, 208, 211 e 212 da Constituição Federal e da nova redação ao art. 60 do ato das disposições constitucionais transitórias. Diário Oficial da União: Brasília, DF, p. 18109, 13 setembro 1996.

BURMEISTER, M.; EILKS, I. Anex ample of learning about plastics and the irevaluation as a contribution to education for sustainable development in secondary school chemistry teaching. Chemistry Education Research and Practice, Cambridge, v. 13, n. 2, p. 93-102, 2012. 
CARVALHO, A. D., VANNUCCHI, A. I., BARROS, M. A., GONÇALVES, M. E. R.; REY, R. D. Ciências no ensino fundamental: o conhecimento físico. São Paulo: Scipione, 1998.

CARVALHO, A. M. P. D. Ensino de ciências por investigação: condições para implementação em sala de aula. São Paulo: Cengage Learning, 2013.

CARVALHO, A. M. P.; LIMA, M. C. B. Comprovando a necessidade dos problemas. In: ENCONTRO NACIONAL DE PESQUISA EM EDUCAÇÃO EM CIÊNCIAS, 2., 1999, Valinhos. Atas [...]. Rio de Janeiro: ABRAPEC, 1999.

COSTA, C. L F. O pensamento científico em Bachelard. In: COLÓQUIO INTERNACIONAL EDUCAÇÃO E CONTEMPORANEIDADE, 6., 2012, São Cristóvão. Anais [...]. São Cristóvão: EDUCON, 2012.

CUEVAS. P.; LEE. O.; HART, A.; DEAKTOR, R. Improving science inquiry with elementar students of diverse backgrounds. Journal of Research in Science Teaching, Hoboken, v. 42, n. 3. p. 337-357, 2005.

DA FONSECA, D. M. A pedagogia científica de Bachelard: uma reflexão a favor da qualidade da prática e da pesquisa docente. Educação e Pesquisa, São Paulo, v. 34 , n. 2, p. 361-370, 2008.

DA RONCH, S. F. A.; DANYLUK, O. S.; ZOCH, A. N. Reflexões epistemológicas no ensino de ciências/química: as potencialidades da pedagogia científica de Bachelard. Revista Brasileira de Ensino de Ciência e Tecnologia, Ponta Grossa, v. 9, n.1, p. 342-353, 2016.

DE ARAUJO, L. F.; DOLINA, J. V.; PETEAN, E.; MUSQUIM, C. A.; BELLATO, R.; LUCIETTO, G. C. Diário de pesquisa e suas potencialidades na pesquisa qualitativa em saúde. Revista Brasileira de Pesquisa em Saúde, Vitória, v. 15, n. 3, p. 53-61, 2013.

DOS REIS, J. M. C.; KIOURANIS, N. M. M.; DA SILVEIRA, M. P. Um olhar para o conceito de átomo: contribuições da epistemologia de Bachelard. Alexandria: revista de educação em ciência e tecnologia, Florianópolis, v. 10, n. 1, p. 3-26, 2017.

EILKS, I.; MARKIC, S. Effects of a long-term participatory action research Project on science teachers' professional development. Eurasia: journal of mathematics, science and technology education, Ankara, v. 7, n. 3, p. 149-160, 2011.

EILKS, I.; RALLE, B. Participatory action research with in chemical education. In: RALLE, B.; EILKS, I. (ed.). Research in chemical education: what does thismean? Aachen: Shaker, 2002. p. 87-98.

FELCHER, C. D. O.; FERREIRA, A. L. A.; FOLMER, V. Da pesquisa-ação à pesquisa participante: discussões a partir de uma investigação desenvolvida no Facebook. Experiências em Ensino de Ciências, Cuiabá, v. 12, n. 7, p. 1-18, 2017. 
FERREIRA, L. H.; HARTWIG, D. R.; OLIVEIRA, R. C. Ensino experimental de química: uma abordagem investigativa contextualizada. Química Nova na Escola, São Paulo, v. 32, n. 2, p. 101-106, 2010.

GEIER, R.; BLUMENFELD, P. C.; MARX, R. W.; KRAJCIK, J. S.; FISHMAN, B.; SOLOWAY, E.; CLAY-CHAMBERS, J. Standardized test outcomes for students engaged in inquiry-based science curricula in the context of urban reform. Journal of Research in Science Teaching, Hoboken, v. 45, n.8, p. 922-939, 2008.

GOMES, H. J. P.; DE OLIVEIRA, O. B. Obstáculos epistemológicos no ensino de ciências: um estudo sobre suas influências nas concepções de átomo. Ciências \& Cognição, Rio de Janeiro, v. 12, p. 96-109, 2007.

GOODEY, N. M.; TALGAR, C. P. Guided inquiry in a biochemistry laboratory course improves experimental design ability. Chemistry Education Research and Practice, Cambridge, v. 17, n. 4, p. 1127-1144,2016.

HERRINGTON, D. G.; YEZIERSKI, E. J.; LUXFORD, K. M.; LUXFORD, C. J. Target inquiry: changing chemistry high school teachers' classroom practices and knowledge and beliefs about inquiry instruction. Chemistry Education Research and Practice, Cambridge, v. 12, n. 1, p. 74-84, 2011.

HOFSTEIN, A.; LUNETTA, V. N. The role of the laboratory in science teaching: neglected aspects of research. Review of Educational Research, Thousand Oaks, v. 52, n. 2, p. 201-217, 1982.

HOFSTEIN, A.P.; LUNETTA, V. The laboratory science education: foundation for the twenty-first century. Science Education, Hoboken, v. 88, p. 28-54, 2003.

JUNTUNEN, M.; AKSELA, M. Life-cycle analysis and inquiry-based learning in chemistry teaching. Science Education International, Izmir, v. 24, n. 2, p. 150-166, 2013.

KASSEBOEHMER, A. C.; FERREIRA, L. H. O método investigativo em aulas teóricas de química: estudo das condições da formação do espírito científico. Revista Electrónica de Enseñanza de lãs Ciencias, Vigo. v. 12, n. 1, p. 144-168, 2013a.

KASSEBOEHMER, A. C.; HARTWIG, D. R.; FERREIRA, L. H. Contém química 2: pensar, fazer e aprender pelo método investigativo. São Carlos: Pedro \& João Editores, 2015.

KASSEBOEHMER, A. C.O método investigativo em aulas teóricas de química: estudo das condições da formação do espírito científico. 180 f. 2011. Tese (Doutorado em Ciências) - Centro de Ciências Exatas e de Tecnologia, Universidade Federal de São Carlos, São Carlos, 2011.

KASSEBOEHMER, A.C.; FERREIRA, L. H. Elaboração de hipóteses em atividades investigativas em aulas teóricas de química por estudantes de ensino médio.

Química Nova na Escola, São Paulo, v. 35, n. 3, p. 158-165, 2013 b. 
LEÃO, D. M. M. Paradigmas contemporâneos de educação: escola tradicional e escola construtivista. Cadernos de pesquisa, São Paulo, v. 107, p. 187-206, 1999.

LÔBO, S. F. O ensino de química e a formação do educador químico, sob o olhar bachelardiano. Ciência \& Educação, Bauru, v. 14, n. 1, p. 89-100, 2008.

LOPES, A.R. C. Contribuições de Gaston Bachelard ao ensino de ciências.Enseñanza de lãs ciencias: revista de investigación y experiencias didácticas, Barcelona, v. 11, n. 3, p. 324-330,1993.

LUDKE, M.; ANDRÉ, M. Pesquisa em educação: abordagens qualitativas. São Paulo: Editora Pedagógica e Universitária, 1986.

MACLIN, D.; GROSSLIGHT, L.; DAVIS, H. Teaching for understanding: a study of students' preinstruction theories of matter and a comparison of the effectiveness of two approaches to teaching about matter and density. Cognition and Instruction, Philadelpha, v. 15, n. 3, p. 317-393, 1997.

MARKS, R; EILKS, I. Promoting scientificl iteracy using a sociocritical and problemoriented approach to chemistry teaching: concept, examples, experiences.

International Journal of Environmental and Science Education, Beckenham, v. 4, n. 3, p. 231-245, 2009.

MORTIMER, E. F.; MACHADO, A. H. Química. 2. ed. São Paulo: Scipione, 2014.

MORTIMER, E. F.; MACHADO, A. H. Química. 3. ed. São Paulo: Scipione, 2017.

MORTIMER, E. F.; MACHADO, A. H.; ROMANELLI, L. I. A proposta curricular de química do estado de Minas Gerais: fundamentos e pressupostos. Química Nova, São Paulo, v. 23, n. 2, p. 273-283, 2000.

MORTIMER, E. F.; MIRANDA, L. C. Transformações: concepções de estudantes sobre reações químicas. Química Nova na Escola, São Paulo, v. 2, p. 23-26, 1995.

MOSS, D. M. Examining student conceptions of the nature of science. International Journal of Science Education, Abingdon, v. 23, n. 8, p. 771-790, 2001.

MUCHTAR, Z. Analyzing of students' misconceptions on acid-base chemistry at senior high schools in medan. Journal of Education and Practice, New York, v. 3, n. 15, p. 65-74, 2012.

NATIONAL RESEARCH COUNCIL. National science education standards. Washington: National Academies Press, 1996.

ÖZMEN, H.; ALIPAŞA, A. Y. A. S. Students' difficulties in understanding of the conservation of matter in open and closed-system chemical reactions. Chemistry Education Research and Practice, v. 4, n. 3, p. 279-290, 2003.

PELLA, M. O. The laboratory and science teaching. The Science Teacher, Washington, v. 28, n. 5 p. 29-31,1961. 
PERREN, M. A.; BOTTANI, E. J.; ODETTI, H. S. Problemas cuantitativos y comprensión de conceptos. Enseñanza de las Ciencias, Barcelona, v. 22, n. 1, p. 105-114, 2004.

POPPER, K. R. A lógica da pesquisa científica. São Paulo: Editora Cultrix, 2004.

PRAIA, J. F.; CACHAPUZ, A. F. C.; GIL-PÉREZ, D. Problema, teoria e observação em ciência: para uma reorientação epistemológica da educação em ciência. Ciência \& Educação, Bauru, v. 8, n. 1, p. 127-145, 2002a.

PRAIA, J.; CACHAPUZ, A.; GIL-PEREZ, D. A hipótese e a experiência científica em educação em ciência: contributos para uma reorientação epistemológica. Ciência \& Educação, Bauru, v. 8, n. 2, p. 253-262, $2002 b$.

REIGADA, C.; REIS, M. F. C. T. Educação ambiental para crianças no ambiente urbano: uma proposta de pesquisa-ação. Ciência \& Educação, Bauru, v. 10, n. 2, p. 149-159, 2004.

RODRIGUES, E. M. Ensino noturno de $2^{\circ}$ Grau: o fracasso da escola ou a escola do fracasso? Educação \& Realidade, Porto Alegre, v. 20, n. 1, 1995.

RUIZ-PRIMO, M. A., LI, M., TSAI, S. P.; SCHNEIDER, J., Testing one premise of scientific inquiry in science classrooms: examining students' scientific explanations and student learning. Journal Research ScienceTeaching, Hoboken, v. 47, n. 5, p. 583-608, 2010.

SÃO PAULO (Estado). Secretaria de Educação. Currículo do Estado de São Paulo: ciências da natureza e suas tecnologias - ensino médio - SEE, São Paulo: Secretaria de Educação, 2011.

SESEN, B. A.; TARHAN, L. Inquiry-based laboratory activities in electrochemistry: high school students' achievements and attitudes. Research in Science Education, Dordrecht, v. 43, n. 1, p. 413-435, 2013.

SILVA, D. M. Estudo da contribuição de um clube de química para a formação do espírito científico. 2017. 124 f. Dissertação (Mestrado em Química) - Instituto de Química de São Carlos, Universidade de São Paulo, São Carlos, 2017.

SILVA, E. L.; SOUZA, F. L.; MARCONDES, M. E. R. "Transformações químicas" e" transformações naturais": um estudo das concepções de um grupo de estudantes do ensino médio. Educación Química, México, v. 19, n. 2, p. 114-120, 2008.

SOLOMON, J.; DUVEEN, J.; SCOT, L. Teaching about the nature of Science through history: action research in the classroom.Journal of Research in Science Teaching, Hoboken, v. 29, n. 4, p. 409-421, 1992.

SOUSA, S. Z.; PORTELA DE OLIVEIRA, R. Ensino médio noturno: democratização e diversidade. Educar em Revista, Curitiba, v. 31, p. 53-72, 2008. 
SUART, R. C.; MARCONDES, M. E. R. A manifestação de habilidades cognitivas em atividades experimentais investigativas no ensino médio de química. Ciências \& Cognição, Rio de Janeiro, v. 14, n. 1, p. pp. 50-74, 2009.

SUART, R. C.; MARCONDES, M. E. R.; CARMO, M. P. Atividades experimentais investigativas: utilizando a energia envolvida nas reações químicas para 0 desenvolvimento de habilidades cognitivas. In: ENCONTRO NACIONAL DE PESQUISA EM EDUCAÇÃO EM CIÊNCIAS, 7., 2009, Florianópolis. Atas [...]. Rio de Janeiro: ABRAPEC, 2009.

SZALAY, L.; TOTH, Z. An inquiry-based approach of traditional 'step-bystep'experiments. Chemistry Education Research and Practice, Cambridge, v. 17, n. 4, p. 923-961, 2016.

TAMIR, P. How are the laboratories used? Journal of Research in Science Teaching, Hoboken, v. 14, n. 4, p. 311-316, 1977.

TOBIN, K. G. Research on science laboratory activities. In pursuit of better questions and answers to improve learning. School Science and Mathematics, Hoboken, v. 90 , p. $403-418,1990$.

TOWNS, M. H.; KREKE, K.; FIELDS, A. An action research project: student perspectives on small-group learning in chemistry. Journal of Chemical Education, Washington, v. 77, n. 1, p. 111, 2000.

TRIPP D. Pesquisa-ação: uma introdução metodológica Educação e Pesquisa, São Paulo, v. 31, n. 3, p. 443-466, 2005.

VELANES, D. Alguns aspectos sobre o novo espírito científico na epistemologia de Gaston Bachelard. Saberes: revista interdisciplinar de filosofia e educação, Natal, v. 1, n. 16, p. 66-82, 2017.

ZAINKO, M. A. S.; PINTO, M. L. A. T.; DE PAULI BETTEGA, M. O. O ensino de segundo grau noturno: ou de como ignorar as necessidades do aluno trabalhador. Em Aberto, Brasília, v. 8, n. 41, 2007.

ZOHAR, A. Result or conclusion? Students' differentiation between experimental results and conclusions. Journal of Biological Education, Philadelphia, v. 32, n. 1, p. 53-59, 1998. 


\section{APÊNDICE A}

Atividade investigativa Dimensão do átomo

Nome ..ํ….... série.........

Dimensão do átomo

A seguir faremos uma experiência, que embora não envolva a natureza ou as propriedades do átomo, servirá para termos uma ideia de como se constroem modelos. O cientista trabalha de maneira parecida. Por isso é que todas as informações a respeito do átomo podem ser obtidas, mesmo que não possamos enxergá-lo.

No bloco que você recebeu existem informações que só podem ser obtidas a partir de modelos, construídos de maneira análoga ao que você fará agora.

Tente reproduzir a caixa do professor com seu conteúdo utilizando os materiais e a caixa do aluno fornecidos pelo professor.

1. Utilize todas as maneiras que achar necessárias (sons, peso etc.) para identificar o seu conteúdo, porém não abra a caixa do professor nesta fase da atividade.

2. 2 caixas plásticas com tampas (professor e aluno)

3. tampas de garrafa plástica

4. tampas de caneta

5. 1 agulha

6. 1 moeda

7. 1 bloco de isopor

8. 1 bolinha de gude

2. Elabore uma lista com todos os materiais que você suspeita haver na caixa.

3. Abra a caixa do professor e compare-a com a outra. Você construiu um modelo igual ao original?

Por quê? 


\section{APÊNDICE B - Densidade dos sólidos}

Nome:

série

\section{Como podemos medir a densidade de um sólido não poroso?}

Densidade dos sólidos:

1 proveta de $100 \mathrm{~mL}$

balança

régua

cronômetro

prego

bola de gude

tampa de caneta

Procedimento:

1. Determine a massa de cada amostra e anote o resultado.

2. Coloque $50 \mathrm{~mL}$ de água na proveta e em seguida adicione a amostra na água. Anote o volume de água deslocado.

3. Use os dados obtidos para calcular a densidade (em $\mathrm{g} / \mathrm{mL}$ ou $\mathrm{g} / \mathrm{L}$ ) aplicando os conceitos de massa e volume na expressão $d=m / V$.

4. Anote abaixo os dados obtidos para cada uma das amostras.

5. Anote suas conclusões. 


\section{APÊNDICE C- Atividade nível 4: chuva ácida}

\section{Caro aluno,}

\section{Informações para o aluno}

Leia o texto abaixo com os seus colegas para realizar atividade.

Mauro leu uma notícia no jornal sobre um vazamento de enxofre que ocorreu em Cubatão. Na notícia havia a informação de que a chuva ácida teria ocorrido na cidade devido a esse vazamento. Mauro ficou intrigado, pois não sabia que o enxofre contribuía para a formação da chuva ácida que provocava, entre outros danos, o estrago em plantações (vide fotos abaixo).
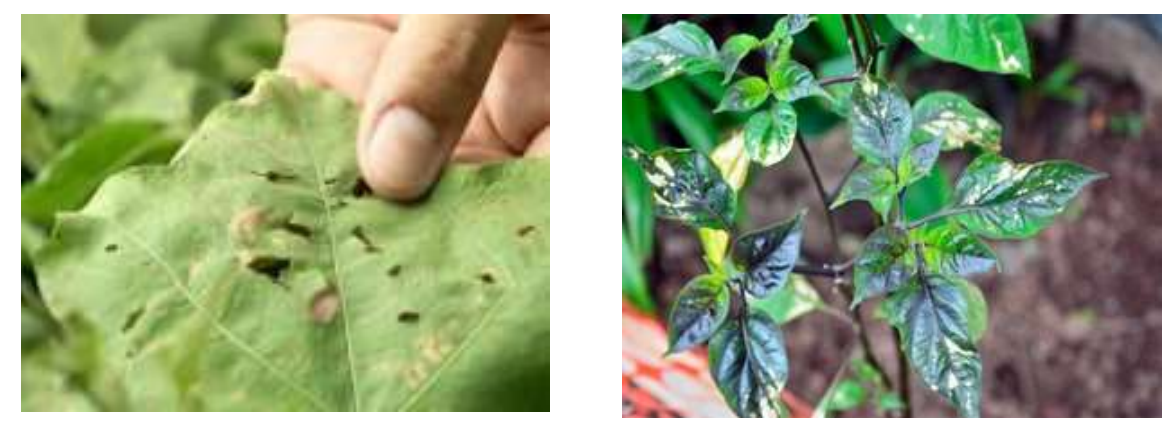

Fig. 1: Vegetação queimada por chuva ácida.

Ajude o Mauro! Utilizando os seus conhecimentos em química, elabore uma hipótese para explicar a relação entre a emissão de certos gases na atmosfera e a chuva ácida.

\section{Pistas}

Pense nos gases que naturalmente compõem a atmosfera e nos gases que podem ser formados a partir da atividade humana.

Explique 0 raciocínio que você utilizou para propor sua(s)
estratégia(s) 


\section{Informações para o aluno}

\section{Algumas reações:}

$\mathrm{Na}$ atmosfera:

$\mathrm{S}(\mathrm{g})+\mathrm{O}_{2}(\mathrm{~g}) \rightarrow \mathrm{SO}_{2}(\mathrm{~g})$

$\mathrm{SO}_{2}(\mathrm{~g})+1 / 2 \mathrm{O}_{2}(\mathrm{~g}) \rightarrow \mathrm{SO}_{3}(\mathrm{~g})$

$\mathrm{SO}_{3}(\mathrm{~g})+\mathrm{H}_{2} \mathrm{O}(\mathrm{g}) \rightarrow \mathrm{H}_{2} \mathrm{SO}_{4}(\mathrm{aq})$

\section{Problema proposto:}

Como você montaria um experimento para mostrar a Mauro como identificar a chuva ácida?

Você tem os seguintes materiais e reagentes disponíveis:

-1 recipiente de vidro transparente com tampa;

-Enxofre em pó;

-Carvão vegetal em pó;

-Água;

-Pétalas de flor colorida;

-Fitas de papel tornassol azul;

-Fita isolante;

-1 vela;

-1 colher;

-1 espátula;

-1 caixa de fósforos.

Descreva detalhadamente o procedimento experimental, os resultados obtidos e suas conclusões. 


\section{APÊNDICE D - Cronograma Experimental}

\section{Parte 1}

Roteiro para preenchimento do formulário de atividades desenvolvidas

Hipótese: na hipótese você deve colocar o que você pensa que pode ocorrer se você fizer uma modificação (deixe claro a modificação que irá realizar!!!) no seu experimento.

Teste: Anote o procedimento experimental que será realizado também anote vidrarias, reagentes, a sequência de adição de reagentes, anote todos os passos realizados até a conclusão do experimento.

Resultados: Anote neste campo as observações realizadas durante o experimento e os resultados que obtiveram resultante de medidas de temperatura, $\mathrm{pH}$, mudança de cor, liberação de gás, etc...

Conclusão: Neste campo você irá responder a sua hipótese, se ele foi válido ou não. Se os resultados foram coerentes explique o porquê você acha isso. Se não foram coerentes explique 0 porquê e quais modificações poderiam ser realizadas para o próximo experimento. 


\section{APÊNDICE D - Parte 2}

Escola José Ferreira da Silva

Grupo. série.....

Data:

Questão de pesquisa: Qual é a pergunta que quero responder, estudar, conhecer e o que posso fazer para responder essa pergunta?

Como será solucionado (hipótese): na hipótese você deve colocar o que você pensa que pode ocorrer se você fizer uma modificação (deixe claro a modificação que irá realizar!!!) no seu experimento.

Teste 1: Anote o procedimento experimental que será realizado também anote vidrarias, reagentes, a sequência de adição de reagentes, anote todos os passos realizados até a conclusão do experimento.

Dados obtidos: Anote neste campo as observações realizadas durante o experimento e os resultados que obtiveram resultante de medidas de temperatura, $\mathrm{pH}$, mudança de cor, liberação de gás, etc...

Conclusão: Neste campo você irá responder a sua hipótese, se ela foi válida ou não. Se os resultados foram coerentes explique o porquê você acha isso. Se não foram coerentes explique 0 porquê e quais modificações poderiam ser realizadas para o próximo experimento. 
Teste 2-Procedimento Experimental- Data:

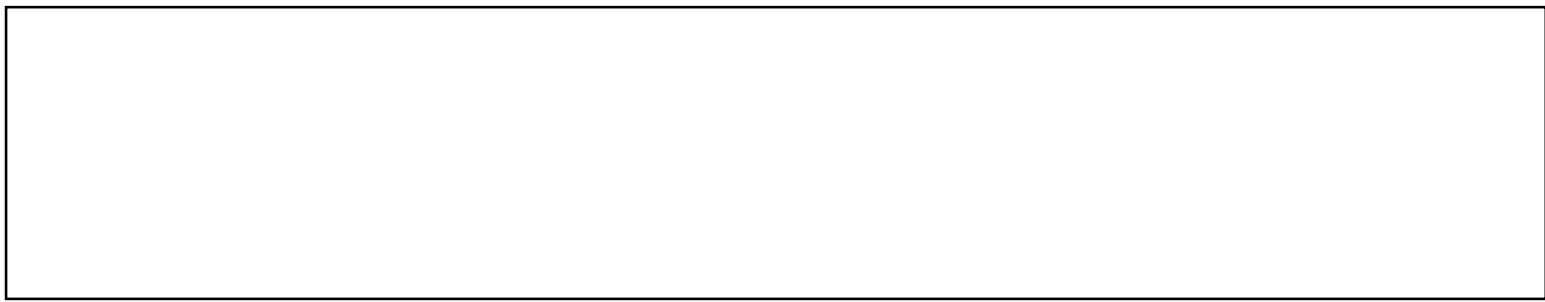

Dados obtidos:

Conclusão:

Teste 3-Procedimento Experimental Data:

Dados obtidos:

Conclusão

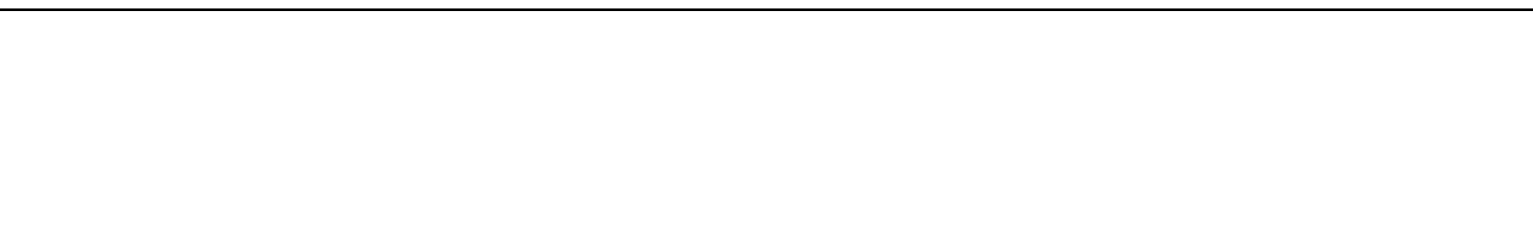


Teste 4:Procedimento Experimental-Data

Dados obtidos:

Conclusão (Final):

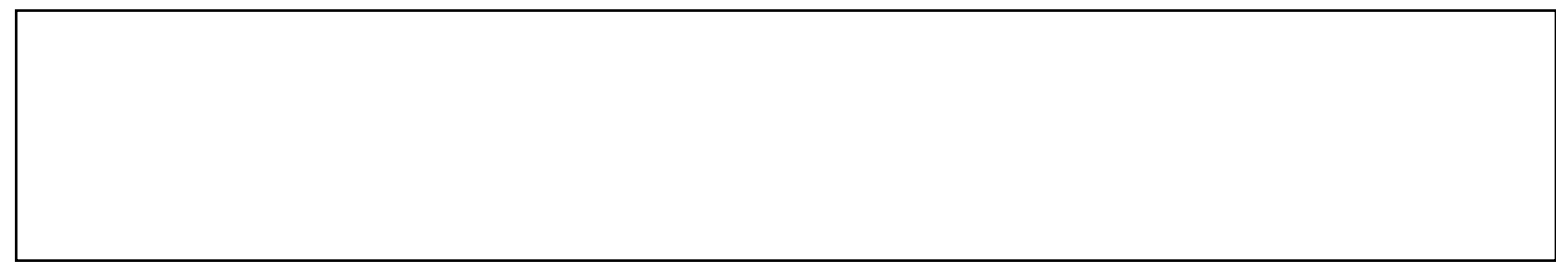




\section{APÊNDICE E - Redação}

Escola:

Nome.

. ${ }^{0} \ldots . . .$. série........

De acordo com as atividades desenvolvidas elabore um texto que contenha os seguintes tópicos:

- O que você aprendeu com a realização das atividades?

- Você ficou pensando no experimento realizado e quais modificações você e seu grupo poderiam realizar?

- Quais dúvidas e dificuldades encontradas durante a realização e modificações dos experimentos?

- Ao final do texto deixe sua opinião, se gostou deste tipo de atividade, se gostaria de mais atividades deste tipo, se faria novamente atividades deste tipo. 


\section{APÊNDICE F - Roteiro entrevista}

\section{Roteiro 1 (Quem participou de todas as atividades)}

1. Como você achou que seria seu desempenho durante as atividades no semestre?

2. E agora como você se sente em relação a suas habilidades após participar de um projeto como esse?

3. O que você acha que é problema? Defina o problema do seu projeto? Tente descrever o que você fez a cada semana.

4. Como era durante a semana você ficava pensando sobre o assunto até ter uma ideia? Quanto tempo, em média, você pensava nas atividades?

5. Você se saiu como esperava? Melhor, pior, por quê?

6. Na sua opinião, participar destas atividades ajudou você a fazer mais perguntas em sala de aula? Ou deixou você mais curioso para aprender Química?

7. Você gostou de realizar as atividades tanto da $1^{\underline{a}}$ parte da estratégia investigativa, quanto da $2^{a}$ fase em que vocês propõem o experimento? Se sim por quê?

\section{Roteiro 2 (Quem participou de algumas atividades)}

1. Por que você participou de algumas atividades?

2. Qual sua avaliação final sobre a inclusão de atividades de investigação em aulas de Química?

3. Você gostaria que as aulas de outras disciplinas ou as aulas de Química nos próximos anos fossem mais parecidas com este projeto?

4. Na sua opinião, participar destas atividades ajudou você a fazer mais perguntas em sala de aula?

5. Ou deixou você mais curioso para aprender Química?

\section{Roteiro 3 (Quem não participou de nenhuma das atividades)}

1. Qual sua avaliação final sobre a inclusão de atividades de investigação em aulas de Química? Você gostaria que as aulas de outras disciplinas ou as aulas de Química nos próximos anos fossem mais parecidas com este projeto?

2.Você tem alguma sugestão para tornar as aulas de Química mais prazerosas? Qual? 


\section{ANEXO A - Questionário inicial}

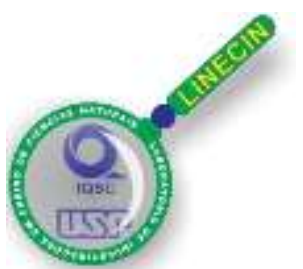

Nome:
UNIVERSIDADE DE SÃO PAULO - USP

LABORATÓRIO DE INVESTIGAÇÃO E ENSINO DE CINÊNCIAS NATURAIS - LINECIN

Que fenômeno está representado nas imagens abaixo?

Explique com base nos seus conhecimentos. Utilize tudo que você aprendeu na escola e fora dela.

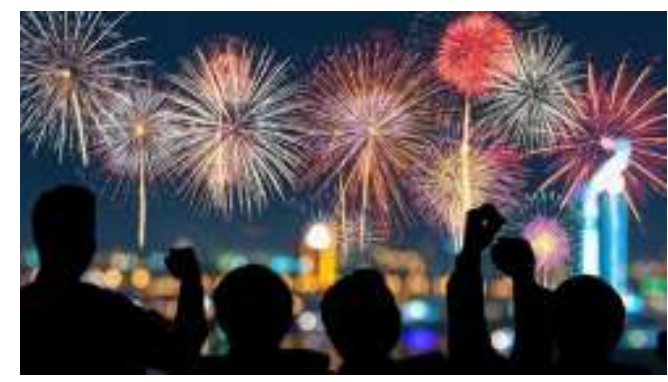

turma:

data_l_ I 


\section{ANEXO B \\ 1. Experimento do livro química Mortimer: Como reconhecer uma transformação química? página 226 - 230.}

\section{Como reconhecer uma transformacão química?}

Nesta atividade, vamos discutir alguns fenômenos, com o objetivo de analisar as características dos materiais antes e depois da transformação que sofreram, evidenciando a ocorrência ou não de reações químicas.

Vamos trabalhar com algumas reações químicas, caracterizando o sistema inicial (antes da transformação) e o sistema final (depois da transformação). Esta atividade tem a finalidade de reconhecer que evidências permitem dizer que uma reação química pode ter ocorrido. Procuraremos, também, evidenciar a produção de novos materiais como garantia de que ocorreu uma reação química.

\section{Parte A - A reação entre ácido clorídrico e zinco}

\section{Material}

Um tubo de ensaio, uma proveta de $5 \mathrm{~mL}$ ou um conta-gotas, pedaços de zinco (pequenos) e solução de ácido clorídrico (HCl) em uma concentração de $1 \mathrm{~mol} / \mathrm{L}$.

\section{O que fazer}

A1 Coloquem aproximadamente $2 \mathrm{~mL}$ (40 gotas) da solução de $\mathrm{HCl}$ no tubo de ensaio. A2 Adicionem um pedaço pequeno de zinco no tubo com a solução.

\section{Questões}

Q1. Descrevam as características macroscópicas do sistema inicial (solução de $\mathrm{HCl}$ e pedaço de zinco separados) antes da imersão do zinco na solução.

Q2. Descrevam as características macroscópicas do sistema quando vocês adicionaram o zinco à solução de $\mathrm{HCl}$.

Q3. Qual é a evidência de que ocorreu uma transformação?

Q4. Como vocês poderiam identificar as novas substâncias que foram formadas?

Q5. Se vocês determinassem a massa $\left(m_{i}\right)$ do sistema inicial (solução de $\mathrm{HCl}$ e zinco separados) e a massa $\left(m_{f}\right)$ do sistema final, depois que a transformação se completou, vocês acham que mi seria maior, menor ou igual a $\mathrm{m}_{\mathrm{f}}$ ? Justifiquem.

Q6. Se a reação tivesse se passado em um sistema fechado, um tubo de ensaio fechado com uma rolha, por exemplo, a resposta ao item Q5 seria a mesma? Justifiquem.

\section{Parte B - A queima de uma fita de magnésio}

\section{Material}

Uma lamparina, uma fita de magnésio e uma garra de madeira.

\section{O que fazer}

A3 Segurem um pedaço da fita de magnésio com a garra e aproximem-na da chama da lamparina, seguindo as orientações de precaução. Nesse procedimento, vocês devem tomar muito cuidado: procurem utilizar o material de proteção adequado para realizá-lo. Se possível, usem óculos de proteção.

\section{Questões}

Q7. Descrevam as características do sistema inicial (fita de magnésio e outro reagente que vocês imaginam que participe da reação), antes da transformação.

Q8. Descrevam as características do sistema final, após queimar a fita de magnésio. 
Q9. Qual é a evidência de que ocorreu uma transformação?

Q10. Como vocês poderiam identificar as novas substâncias que foram formadas?

Q11. Se vocês determinassem a massa inicial do sistema $\left(m_{i}\right)$ e a massa final do sistema $\left(m_{\mathrm{f}}\right)$, depois que a transformação se completou, vocês acham que mi seria maior, menor ou igual a $m_{f}$ ? Justifiquem.

Q12. Se a reação tivesse se passado em um sistema fechado, um tubo de ensaio fechado com uma rolha, por exemplo, a resposta ao item Q11 seria a mesma? Justifiquem.

\section{Parte C - Reação entre soluções de hidróxido de sódio e sulfato de cobre (II)}

\section{Material}

Solução de hidróxido de sódio $(\mathrm{NaOH}) 0,1 \mathrm{~mol} / \mathrm{L}$, solução de sulfato de cobre (II) $\left(\mathrm{CuSO}_{4}\right)$ $0,1 \mathrm{~mol} / \mathrm{L}$, um tubo de ensaio e uma proveta de $5 \mathrm{~mL}$ ou um conta-gotas.

\section{O que fazer}

A4 Coloquem aproximadamente $2 \mathrm{~mL}$ (40 gotas) de solução de $\mathrm{NaOH} \mathrm{0,1} \mathrm{mol/L} \mathrm{em} \mathrm{um} \mathrm{tubo}$ de ensaio.

A5 Em seguida, adicionem aproximadamente a mesma quantidade da solução $\mathrm{CuSO}_{4}$ 0,1 $\mathrm{mol} / \mathrm{L}$ ao tubo com a solução de $\mathrm{NaOH}$.

\section{Questões}

Q13. Descrevam as características do sistema inicial (soluções de $\mathrm{NaOH}$ e de CuSO4).

Q14. Descrevam as características do sistema após a adição da solução de CuSO4 à solução de $\mathrm{NaOH}$.

Q15. Qual a evidência de que ocorreu uma transformação?

Q16. Como vocês poderiam identificar as novas substâncias que foram formadas?

Q17. Se vocês determinassem a massa inicial $\left(m_{i}\right)$ do sistema (solução de $\mathrm{NaOH}$ e solução de $\mathrm{CuSO}_{4}$ separadas) e a massa final $\left(\mathrm{m}_{\mathrm{f}}\right)$ do sistema, depois que a transformação se completou, vocês acham que mi seria maior, menor ou igual a $\mathrm{m}_{\mathrm{f}}$ ? Justifiquem.

Q18. Se a reação tivesse se passado em um sistema fechado, um tubo de ensaio fechado com uma rolha, por exemplo, a resposta ao item Q17 seria a mesma? Justifiquem.

\section{Parte D - Reação entre soluções de ácido clorídrico e hidróxido de sódio}

\section{Material}

Solução de hidróxido de sódio $(\mathrm{NaOH}) 5 \mathrm{~mol} / \mathrm{L}$, ácido clorídrico $(\mathrm{HCl}) 5 \mathrm{~mol} / \mathrm{L}$, um tubo de ensaio e uma proveta de $5 \mathrm{~mL}$ ou um conta-gotas.

\section{O que fazer}

A6 Coloquem aproximadamente $2 \mathrm{~mL}$ (40 gotas) da solução de $\mathrm{NaOH} 5 \mathrm{~mol} / \mathrm{L}$ em um tubo de ensaio.

A7 Em seguida, adicionem aproximadamente a mesma quantidade de solução de $\mathrm{HCl}$ ao tubo com a solução de $\mathrm{NaOH}$.

\section{Questões}

Q19. Descrevam as características do sistema inicial (solução de $\mathrm{HCl}$ e solução de $\mathrm{NaOH}$ ) antes da transformação.

Q20. Descrevam as características do sistema após a adição da solução de $\mathrm{HCl}$ à solução de $\mathrm{NaOH}$.

Q21. Qual a evidência de que está ocorrendo uma transformação?

Q22. Como vocês poderiam identificar as novas substâncias que foram formadas nesta atividade? 
Q23. Se vocês determinassem a massa inicial $\left(m_{i}\right)$ do sistema (solução de $\mathrm{NaOH}$ e solução de $\mathrm{HCl}$ separados) com a massa final $\left(\mathrm{m}_{\mathrm{f}}\right)$ do sistema, depois que a transformação se completou, vocês acham que mi seria maior, menor ou igual a $\mathrm{m}_{\mathrm{f}}$ ? Justifiquem.

Q24. Se a reação tivesse se passado em um sistema fechado, por exemplo num tubo de ensaio fechado com uma rolha, a resposta ao item Q23 seria a mesma? Justifiquem.

\section{Parte E - Reação entre soluções de ácido clorídrico e hidróxido de sódio na presença de fenolftaleína}

\section{Material}

Solução de hidróxido de sódio $(\mathrm{NaOH}) 5 \mathrm{~mol} / \mathrm{L}$, solução alcoólica de fenolftaleína, solução de ácido clorídrico $(\mathrm{HCl}) 5 \mathrm{~mol} / \mathrm{L}$, um tubo de ensaio e uma proveta de $5 \mathrm{~mL}$ ou um contagotas.

\section{O que fazer}

A8 Coloquem aproximadamente $2 \mathrm{~mL}$ (40 gotas) de $\mathrm{NaOH} 5 \mathrm{~mol} / \mathrm{L}$ no tubo de ensaio.

A9 Adicionem, ao mesmo tubo, 2 gotas da solução alcoólica de fenolftaleína e agite, levemente, o tubo.

A10 Em seguida, adicionem a solução de $\mathrm{HCl} 5 \mathrm{~mol} / \mathrm{L}$ ao mesmo tubo, até dobrar o volume da solução e agite, levemente, o tubo.

\section{Questões}

Q25. Descrevam as características do sistema inicial (solução de $\mathrm{NaOH}$, solução de fenolftaleína e solução de $\mathrm{HCl}$ ) antes da transformação.

Q26. Descrevam as características do sistema quando vocês adicionaram gotas da solução de fenolftaleína à solução de $\mathrm{NaOH}$.

Q27. Qual a evidência de que ocorreu uma transformação?

Q28. Como vocês poderiam identificar as novas substâncias que foram formadas?

Q29. Descrevam as características do sistema quando vocês adicionaram a solução de $\mathrm{HCl}$ à solução de $\mathrm{NaOH}$ contendo gotas da solução de fenolftaleína.

Q30. Qual a evidência de que ocorreu uma transformação?

Q31. Como vocês poderiam identificar as novas substâncias que foram formadas? 
ANEXO C - Atividade investigativa nível 4, conservação da massa.

Parte 1

\section{Informações para o aluno}

Caro aluno,

Leia o texto abaixo com os seus colegas para realizar a primeira parte da atividade.

Aline precisava tomar um remédio, o qual vinha na forma de comprimido efervescente. A caixa do medicamento dizia que cada comprimido pesava $4,85 \mathrm{~g}$. Então Aline pegou um copo com 100ml de água e adicionou o comprimido, rapidamente o comprimido desapareceu. Aline ficou curiosa e resolveu pesar o copo com a solução, mas ao pesar ela tomou um susto! Aline sabia que o copo pesava $100 \mathrm{~g}$ e que a quantidade de água pesava $100 \mathrm{~g}$ mais o peso do comprimido $(4,85 \mathrm{~g})$, então a balança deveria marcar 204,85g, certo? Mas ao invés disso, ela estava marcando 203,5g.

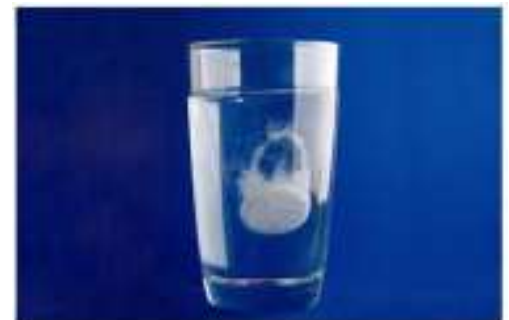

Fonte: http://www.habanaradio.cu/wp-content/blogs.dir/2/files/sites/2/2013/10/antiacidos.jpg

Ajude a Aline.

Elabore uma explicação para a diminuição da massa do sistema, utilizando conceitos químicos e considerando que não houve erro de manipulação pela Aline.

(Se preferir, você pode utilizar um desenho para ajudar a explicar seu modelo).

\section{Pistas}

1.Pense no que ocorre quando o comprimido entra em contato com a água.

Explique o raciocínio que você utilizou para propor sua(s) estratégia(s): 
ANEXO C - Atividade investigativa nível 4, conservação da massa.

Parte 2

\section{Alguns tipos de reações}

\section{Informações para o aluno}

Bicarbonato de Sódio + Ácido acético $\rightarrow$ acetato de sódio + água + gás carbônico

$\mathrm{NaHCO}_{3}+\mathrm{CH}_{3} \mathrm{COOH} \rightarrow \mathrm{CH}_{3} \mathrm{COONa}+\mathrm{H}_{2} \mathrm{O}+\mathrm{CO}_{2}$

Papel + oxigênio $\rightarrow$ cinza + produtos gasosos

Ferro + oxigênio $\rightarrow$ óxido de ferro (ferrugem)

\section{Problema proposto}

Como podemos provar que depois de uma reação, a massa final é igual à massa inicial?

Você tem os seguintes materiais e reagentes disponíveis:

- Folha de papel

- Palha ou lã de aço

- Palitos de fósforo

- Uma balança

- Balão de festa

- Erlenmeyer

- Béquer

- Espátula

- Balança

- Bicarbonato de sódio $\left(\mathrm{NaHCO}_{3}\right)$

- Vinagre (solução aquosa de acido acético, $\mathrm{CH}_{3} \mathrm{COOH}$ )

Descreva detalhadamente o procedimento experimental que você deve adotar para provar que depois de uma reação, a massa final é igual à massa inicial.

Procedimento

Resultados:

Conclusão 